DiRECTEURS de LA PUBLICATION / PUBLICATION DIRECTORS:

Bruno David, Président du Muséum national d'Histoire naturelle

Étienne Ghys, Secrétaire perpétuel de l'Académie des sciences

RÉDACTEURS EN CHEF / EDITORS-IN-CHIEF: Michel Laurin (CNRS), Philippe Taquet (Académie des sciences)

ASSISTANTE DE RÉDACTION / AsSISTANT EDITOR: Adenise Lopes (Académie des sciences; cr-palevol@academie-sciences.fr)

MISE EN PAGE / PAGE LAYOUt: Audrina Neveu et Fariza Sissi (Muséum national d'Histoire naturelle; audrina.neveu@mnhn.fr)

RÉVISIONS LINGUISTIQUES DES TEXTES ANGLAIS / ENGLISH LANGUAGE REVISIONS: Kevin Padian (University of California at Berkeley)

RÉDACTEURS ASSOCIÉS / ASSOCIATE EDITORS:

Micropaléontologie/Micropalaeontology

Maria Rose Petrizzo (Università di Milano, Milano)

Paléobotanique/Palaeobotany

Cyrille Prestianni (Royal Belgian Institute of Natural Sciences, Brussels)

Evelyn Kustatscher* (Museum of Nature South Tyrol, Bozen/Bolzano)

Métazoaires/Metazoa

Annalisa Ferretti (Università di Modena e Reggio Emilia, Modena)

Paléoichthyologie/Palaeoichthyology

Philippe Janvier (Muséum national d'Histoire naturelle, Académie des sciences, Paris)

Amniotes du Mésozoïque/Mesozoic amniotes

Hans-Dieter Sues (Smithsonian National Museum of Natural History, Washington)

Tortues/Turtles

Juliana Sterli (CONICET, Museo Paleontológico Egidio Feruglio, Trelew)

Lépidosauromorphes/Lepidosauromorphs

Hussam Zaher (Universidade de São Paulo)

Oiseaux/Birds

Eric Buffetaut (CNRS, École Normale Supérieure, Paris)

Paléomammalogie (mammifères de moyenne et grande taille)/Palaeomammalogy (large and mid-sized mammals)

Lorenzo Rook (Università degli Studi di Firenze, Firenze)

Paléomammalogie (petits mammifères sauf Euarchontoglires)/Palaeomammalogy (small mammals except for Euarchontoglires)

Robert Asher (Cambridge University, Cambridge)

Paléomammalogie (Euarchontoglires)/Palaeomammalogy (Euarchontoglires)

K. Christopher Beard (University of Kansas, Lawrence)

Paléoanthropologie/Palaeoanthropology

Roberto Macchiarelli (Université de Poitiers, Poitiers)

Archéologie préhistorique/Prehistoric archaeology

Marcel Otte (Université de Liège, Liège)

RÉFÉRÉS / REVIEWERS: https://sciencepress.mnhn.fr/fr/periodiques/comptes-rendus-palevol/referes-du-journal

COUVERTURE / COVER:

Made from the Figures of the article.

Comptes Rendus Palevol est indexé dans / Comptes Rendus Palevol is indexed by:

- Cambridge Scientific Abstracts

- Current Contents ${ }^{\circledR}$ Physical

- Chemical, and Earth Sciences ${ }^{\circledR}$

- ISI Alerting Services ${ }^{\circledR}$

- Geoabstracts, Geobase, Georef, Inspec, Pascal

- Science Citation Index ${ }^{\circledR}$, Science Citation Index Expanded ${ }^{\circledR}$

- Scopus ${ }^{\circledR}$.

Les articles ainsi que les nouveautés nomenclaturales publiés dans Comptes Rendus Palevol sont référencés par /

Articles and nomenclatural novelties published in Comptes Rendus Palevol are registered on:

- ZooBank ${ }^{\circledR}$ (http://zoobank.org)

Comptes Rendus Palevol est une revue en flux continu publiée par les Publications scientifiques du Muséum, Paris et l'Académie des sciences, Paris Comptes Rendus Palevol is a fast track journal published by the Museum Science Press, Paris and the Académie des sciences, Paris

Les Publications scientifiques du Muséum publient aussi / The Museum Science Press also publish:

Adansonia, Geodiversitas, Zoosystema, Anthropozoologica, European Journal of Taxonomy, Naturae, Cryptogamie sous-sections Algologie, Bryologie, Mycologie.

L'Académie des sciences publie aussi / The Académie des sciences also publishes:

Comptes Rendus Mathématique, Comptes Rendus Physique, Comptes Rendus Mécanique, Comptes Rendus Chimie, Comptes Rendus Géoscience, Comptes Rendus Biologies.

Diffusion - Publications scientifiques Muséum national d'Histoire naturelle

CP $41-57$ rue Cuvier F-75231 Paris cedex 05 (France)

Tél. : 33 (0)140794805 / Fax: 33 (0)140793840

diff.pub@mnhn.fr / https://sciencepress.mnhn.fr

Académie des sciences, Institut de France, 23 quai de Conti, 75006 Paris.

(C) Publications scientifiques du Muséum national d'Histoire naturelle / @ Académie des sciences, Paris, 2021

ISSN (imprimé / print): 1631-0683/ ISSN (électronique / electronic) : 1777-571X 


\title{
Macrofloral and microfloral changes in the Middle Jurassic plant assemblages of the Cianowice 2 borehole (southern Poland)
}

\author{
Maria BARBACKA \\ W. Szafer Institute of Botany, Polish Academy of Sciences, \\ ul. Lubicz 46, 31-512 Kraków (Poland) \\ and Hungarian Natural History Museum, Botanical Department, \\ H-1431 Budapest, P.O. box 137 (Hungary) \\ maria.barbacka@gmail.com (corresponding author)
}

Artur GÓRECKI

Department of Taxonomy, Phytogeography and Palaeobotany, Institute of Botany, Faculty of Biology, Jagiellonian University, Gronostajowa 3, 30-387 Kraków (Poland) artur.gorecki@doctoral.uj.edu.pl

Jadwiga ZIAJA

W. Szafer Institute of Botany, Polish Academy of Sciences, ul. Lubicz 46, 31-512 Kraków (Poland) j.ziaja@botany.pl

Agata JARZYNKA Institute of Geological Sciences, Polish Academy of Sciences, Senacka 1, 31-002 Kraków (Poland) a.jarzynka@ingpan.krakow.pl

Grzegorz PACYNA Department of Taxonomy, Phytogeography and Palaeobotany, Institute of Botany, Faculty of Biology, Jagiellonian University, Gronostajowa 3, 30-387 Kraków (Poland) grzegorz.pacyna@uj.edu.pl

Barbacka M., Górecki A., Ziaja J., Jarzynka A. \& Pacyna G. 2021. - Macrofloral and microfloral changes in the Middle Jurassic plant assemblages of the Cianowice 2 borehole (southern Poland). Comptes Rendus Palevol 20 (34): 701-739. https://doi.org/10.5852/cr-palevol2021v20a34

\section{ABSTRACT}

The flora of the Cianowice 2 borehole (c. $20 \mathrm{~km} \mathrm{NW}$ of Cracow, Poland), dominated by cycadophytes (mainly bennettitaleans) and conifers, shows high taxonomic diversity relative to the low number of specimens. Twenty species were identified in the 96 determinable plant fragments found in 27 core samples: Cladophlebis sp. (ferns), Pachypteris rhomboidalis (Ettingshausen) Nathorst and Ptilozamites cycadea (Berger) Möller (seed ferns), Anomozamites nilssonii (Phillips) Seward, Nilssoniopteris solitaria 
KEY WORDS

Bennettitalean

dominance, sporomorphs, palaeoenvironment reconstruction.
MOTS CLÉS

Dominance des

bennettitales,

sporomorphes,

reconstruction de
(Phillips) Cleal \& Rees, Otozamites mimetes Harris, Otozamites parallelus Phillips, Pterophyllum thomasii Harris, Pterophyllum cf. aequale (Brongniart) Nathorst, Ptilophyllum cf. okribense forma ratchiana Doludenko \& Svanidze, Ptilophyllum pecten Phillips, Ptilophyllum sirkennethii Watson \& Sincock, Cycadolepis sp. (bennettitaleans), Pseudotorellia grojecensis Reymanówna, Pseudotorellia samylinae Nosova \& Kiritchkova, Pseudotorellia sp. (Gymnospermae incertae sedis), Bilsdalea dura Harris, Mirovia szaferi Reymanówna, and Brachyphyllum stemonium Kendall (conifers). The floristic composition is supplemented by palynological data. The taxa were connected to five depositional successions distinguished along the core: one, alluvial fans; two, four and five, meandering/ anastomosing river depositional systems with fluvial plain deposits; and three, lacustrine/backswamp environment developed on fluvial plain. The composition of the fossil plant assemblage changes with the depositional setting within the same range of taxa, seen mainly in changed combinations of taxa, which are most diverse in the fluvial plain deposits. Some taxa occur in a single depositional succession; some are present in two or three. The sporomorph assemblages of particular depositional environments differ significantly from the composition of the co-occurring macroflora: ferns occur sporadically in the macroflora of each depositional environment but they strongly dominate the sporomorph assemblage. Our proposed reconstruction of the palaeoenvironment is a slight rise descending into a valley with a depositionary basin, with gymnosperms on the slope and ferns at the base. Some species are shared between Cianowice and nearby Middle Jurassic localities in Grojec and Zabierzów, and the majority of taxa are known from the Middle Jurassic, suggesting that the Cianowice deposits are of that age.

\section{RÉSUMÉ}

Changements macrofloristiques et microflorisiques dans les communautés de plantes du Jurassique moyen du forage Cianowice 2 (Pologne méridionale).

La flore du forage Cianowice 2 (c. $20 \mathrm{~km}$ au nord-ouest de Cracovie, Pologne), dominée par les cycadophytes (surtout des bennettitales) et les conifères, montre une diversité taxonomique élevée par rapport au petit nombre d'échantillons. Vingt taxons ont été identifiés à partir des 96 fragments de plantes déterminables trouvés dans 27 échantillons du carottage : Cladophlebis sp. (fougères), Pachypteris rhomboidalis ((Ettingshausen) Nathorst et Ptilozamites cycadea (Berger) Möller (ptéridospermes), Anomozamites nilssonii (Phillips) Seward, Nilssoniopteris solitaria (Phillips) Cleal \& Rees, Otozamites mimetes Harris, Otozamites parallelus Phillips, Pterophyllum thomasii Harris, Pterophyllum cf. aequale (Brongniart) Nathorst, Ptilophyllum cf. okribense forma ratchiana Doludenko \& Svanidze, Ptilophyllum pecten Phillips, Ptilophyllum sirkennethii Watson \& Sincock, Cycadolepis sp. (bennettitales), Pseudotorellia grojecensis Reymanówna, Pseudotorellia samylinae Nosova \& Kiritchkova, Pseudotorellia sp. (Gymnospermae incertae sedis), Bilsdalea dura Harris, Mirovia szaferi Reymanówna, and Brachyphyllum stemonium Kendall (conifères). La composition floristique est complétée par des données palynologiques. Les taxons ont été reliés aux cinq successions principales de dépôt, reconnues au long du forage : un : cônes alluviaux; deux, quatre et cinq : dépôts de rivières à méandres et anastomoses; et trois : plan d'eau de plaine fluviale. La composition des assemblages de plantes fossiles varie généralement avec l'environnement de dépôt au sein d'une même gamme de taxons, principalement dans des combinaisons modifiées de taxons, qui sont les plus diverses dans les dépôts de plaine fluviale. Certains taxons sont spécifiques d'une seule succession de dépôts, d'autres le sont de deux ou trois. Les sporomorphes d'environnements particuliers de dépôt sont significativement différents de la composition de la macroflore co-occurrente : les fougères ne se rencontrent que sporadiquement dans la macroflore de chaque environnement de dépôt, mais dominent fortement les assemblages de sporomorphes. La reconstitution environnementale que nous proposons consiste en une colline basse s'abaissant vers une vallée avec un bassin de dépôt, la pente étant garnie de gymnospermes et le piémont de fougères. Certaines espèces sont partagées entre Cianowice et les localités voisines du Jurassique moyen de Grojec et Zabierzów. La majorité des taxons sont connus du Jurassique moyen, suggérant que les dépôts de Cianowice sont de cet âge.

\section{INTRODUCTION}

Early and Middle Jurassic floras are each known from several areas of Europe (for details see Barbacka et al. 2014a). Among the most important Early Jurassic localities are:
Scoresby Sound (Greenland; Harris 1937), Franken (Germany; Weber 1968), Scania (Sweden; Brongniart 1825; Nathorst 1886, 1909; Pott \& McLoughlin 2009), Holy Cross Mts. (Poland; Makarewiczówna 1928; Barbacka et al. 2010, 2014b; Pacyna 2013), Mecsek Mts. (Hungary; 
e.g. Barbacka 2011), and localities in Serbia (DjordjevićMilutinović 2010). The most famous Middle Jurassic floras are from: Andoya (Norway; Manum et al. 1991), Yorkshire and Stonesfield (e.g. Harris 1949, 1952, 1961, 1969, 1979; Harris \& Millington 1974; Van Konijnenburg-van Cittert \& Morgans 1999; Cleal \& Rees 2003), and the Grojec area (Poland; e.g. Raciborski 1894; Reymanówna 1963b, 1977, 1985; Jarzynka 2012, 2016; Jarzynka \& Pacyna 2015), as well as some Early and Middle Jurassic localities in France (Brongniart 1828a; Saporta 1873-1891; Philippe et al. 1998), Italy (e.g. Krasser 1912; Scanu et al. 2015; Costamagna et al. 2018) and Romania (Dragastan \& Bărbulescu 1977-78; Popa 1997a, b, 1998, 2000a, 2014; Popa \& Van Konijnenburg-van Cittert 2006). Late Jurassic floras are known from only five areas (Barbacka et al. 2014a).

Middle Jurassic localities are generally poorer in taxa (8-38) than the Early Jurassic ones (usually 30-100+), with the exception of Yorkshire, which is extremely rich and diverse (197 taxa; e.g. Harris 1961, 1964, 1969, 1979; Harris \& Millington 1974; Harris \& Miller 1974; Barbacka et al. 2014a). All plant groups are most diverse in the Early Jurassic. In Middle Jurassic floras the percentage of bennettitaleans is relatively high, and bennettitalean-dominated assemblages are known from some localities such as Mamers (Lemoigne 1968; Philippe et al. 1998) and Sardinia (Tornquist 1904; Krasser 1912, 1913, 1920; Edwards 1929; Comaschi Caria 1959; Dieni et al. 1983; Salard-Cheboldaeff \& Vozenin-Serra 1984; Scanu et al. 2015).

Polish Jurassic floras are known from three main areas. The first is at the northern margin of the Holy Cross Mountains, with Early Jurassic localities: Gromadzice (e.g. Makarewiczówna 1928; Pacyna 2013), Chmielów (e.g. Reymanówna 1963a; Pacyna 2013), Odrowąż (Barbacka et al. 2010; Pacyna 2013), Studzianna and Huta (Pacyna 2013; Barbacka et al. 2014b) and some other smaller sites (Pacyna 2013). The second area, with Middle Jurassic plant assemblages, is near Cracow in Grojec (Raciborski 1894; Reymanówna 1963b), Zabierzów and Mirów (Reymanówna 1985) and Cianowice (this paper). In the third area, in central Poland, sporadic Jurassic plant fossils are known only from deep boreholes such as Brześć Kujawski, Ciechocinek (Barbacka et al. 2014b) and Kaszewy (under study).

In the richest of these localities - Grojec - ferns are abundant and diverse; in other localities ginkgophytes or conifers are also quite common. Bennettitaleans are frequent, but so far the flora from the Cianowice borehole is the first in Poland with such significant dominance of this plant group. Thanks to the particular mode of accumulation and good preservation of plant remains, despite a limited sampling opportunity, it was possible to obtain enough data on the assemblages along several levels representing different environmental conditions. The present paper gives a taxonomic review of this very interesting flora, supplemented by palynological data, and discusses its possible connection with environmental change. Since the macroflora suggests domination of bennettitaleans with lower shares of other plant groups, we focus on similar floras known mainly from the Middle Jurassic.

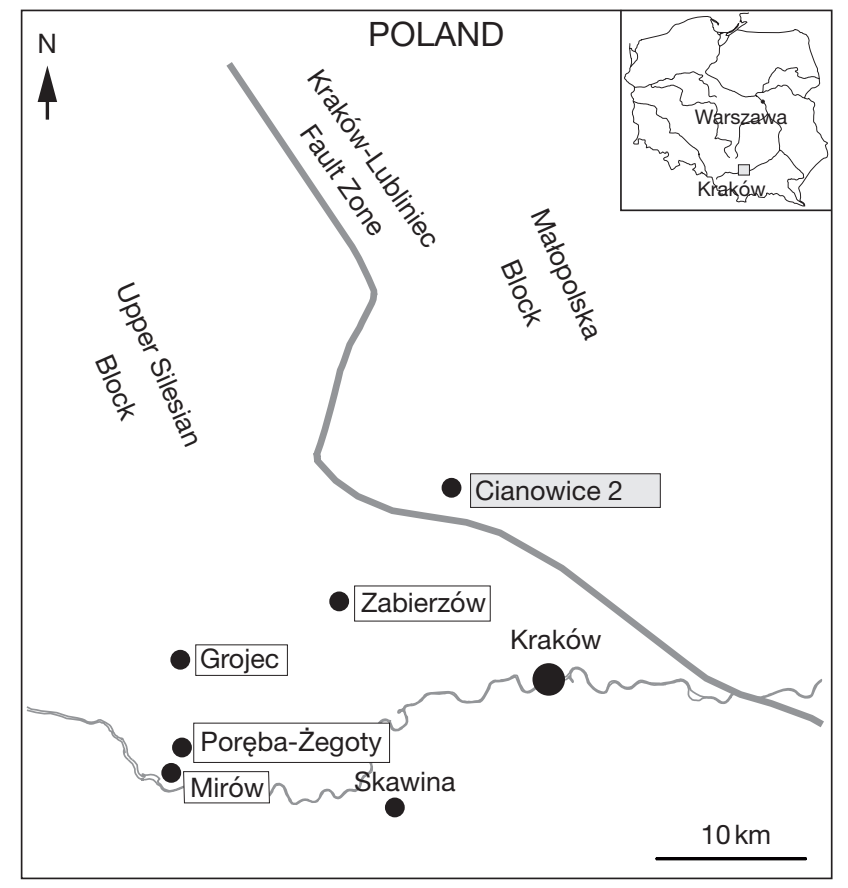

FIG. 1. - Location of the Cianowice 2 borehole and other Middle Jurassic localities mentioned in the paper (after Pieńkowski 2014, modified).

\section{LOCALITY AND GEOLOGICAL SETTINGS}

We studied material from the Cianowice 2 borehole, located in southern Poland c. $20 \mathrm{~km} \mathrm{NW}$ of Cracow, in the vicinity of the Krzeszowice Graben and Kraków-Lubliniec Suture Zone. This zone, marking the contact between Baltica and the Palaeozoic European platform, is an important, long-lived strike-slip feature, finally closed during late stages of the Variscan collision in the late Carboniferous to early Permian (Żaba 1999; Żelaźniewicz et al. 2016). This is the contact zone between two regional tectonic units: the Upper Silesian Block and the Małopolska (Lesser Poland) Block (Fig. 1). The drill core reached the Ediacaran anchimetamorphic rock (mainly shale, claystone and subordinate sandstone) at $600 \mathrm{~m}$ depth (Fig. 2). The studied part of the profile includes depths from $600 \mathrm{~m}$ to $265.2 \mathrm{~m}$ (Habryn et al. 2014). Ore mineralization of the oldest rocks in the profile is very poor but suggests hydrothermal activity and a low-temperature regime (Markowiak 2014).

During the period documented in the Lower Jurassic, the study site was largely a land area, with numerous freshwater basins, characterized by mainly terrestrial sedimentation (Jurkiewiczowa 1974). During the late Bathonian and Callovian, the marine transgression (NW to SE) flooded the Cracow area (Dayczak-Calikowska et al. 1997; Matyja \& Ziółkowski 2014) and reached its maximum during the Oxfordian (Jurkiewiczowa 1974; Matyja \& Ziółkowski 2014).

Geological and sedimentological analyses of two parts (lowerterrestrial; upper-marine) of the Jurassic profile were carried out by Pieńkowski (2014) and by Matyja \& Ziółkowski (2014) respectively. The lower, terrestrial sequence is $21.2 \mathrm{~m}$ thick and composed of grey, brown and green-grey terrigenous deposits. The whole siliciclastic complex is divided into five successions 


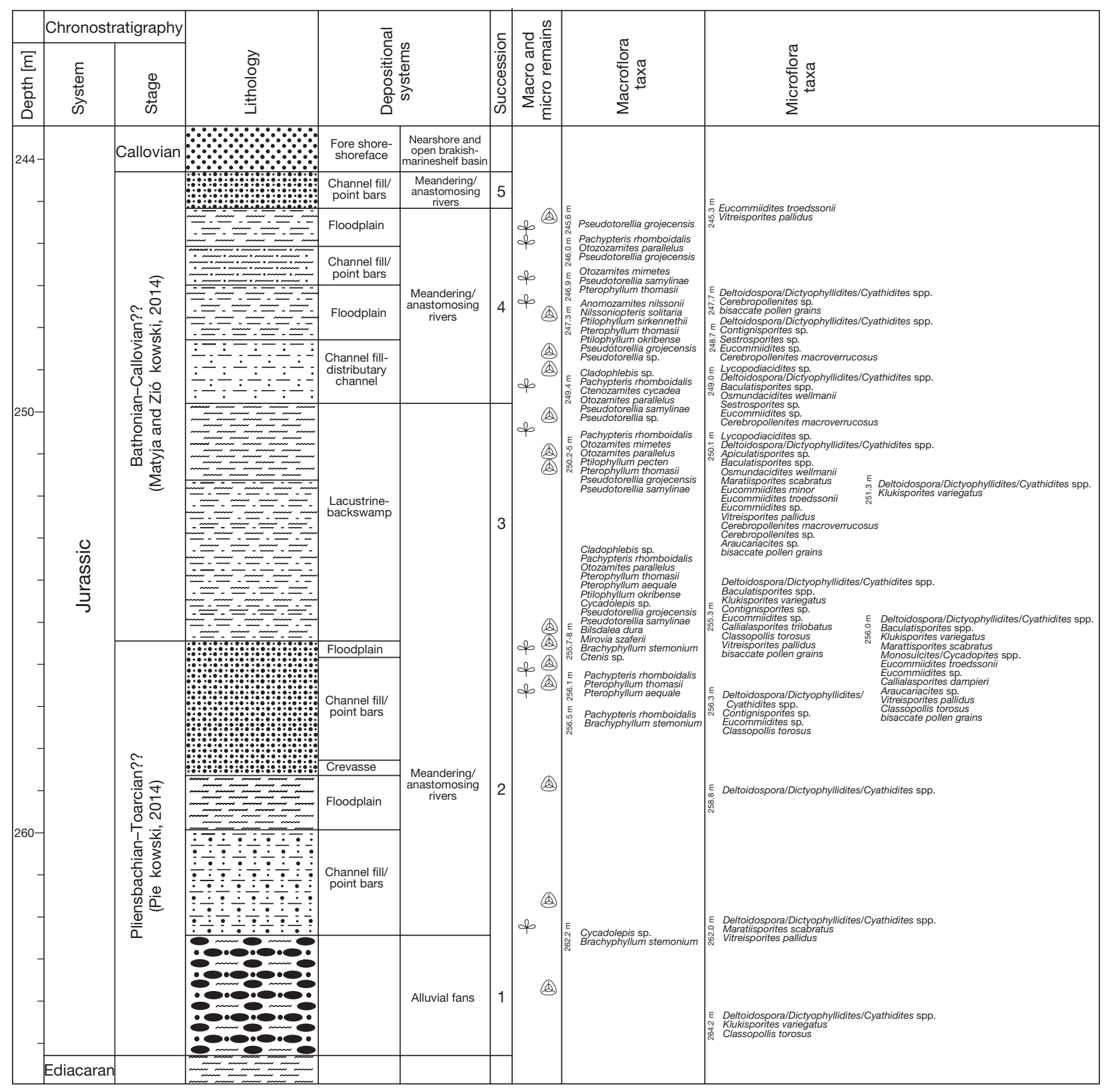

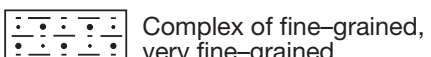 $\begin{array}{ll} & \text { very fine-grained } \\ \text { sandstones and siltstones }\end{array}$}
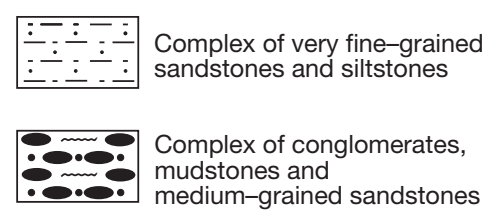
Complex of conglomerates,
mudstones and medium-grained sandstones

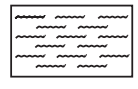

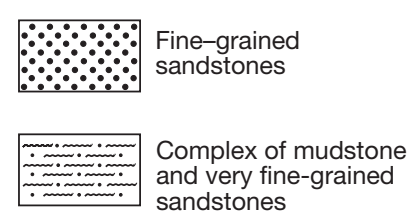
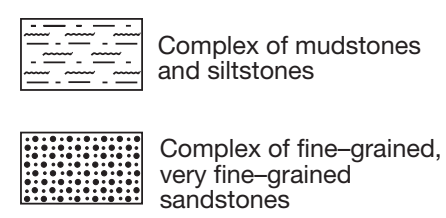

5 Succession 5 \& Plant remains

4 Succession 4 (d) Microflora

3 Succession 3

2 Succession 2

1 Succession 1

FIG. 2. - Simplified lithological profile of the Cianowice 2 borehole (after Pieńkowski 2014, modified). 
connected mainly with meandering/anastomosing river systems (plant fossils are especially rich in fluvial plain and lacustrine sediments). Immediately overlying the erosional unconformity above the Neoproterozoic deposits are breccias and conglomerates, with undeterminable drifted plant fragments and sporomorphes which were examined. This part extends upward to $264.4 \mathrm{~m}$ depth and is assigned by Pieńkowski (2014) to depositional succession 1 - alluvial fans with three cycles separated by erosional unconformities. According to Pieńkowski (2014), succession $2(255.5-262.4 \mathrm{~m})$ is formed by fine-grained and very fine-grained sandstone, mudstone-claystone and siltstonemudstone developed in five cycles. Horizons with plant remains and palaeosols with siderite concretions were recognised within this section. This part represents a depositional system of meandering/anastomosing rivers with channel fills and floodplain, levee and crevasse-splay deposits. The bounding surface between successions 2 and 3 represents a rise in the water table, which could be associated with a rise in the base level. Siderites and plant remains deposited in a lacustrine environment occur above mudstones, claystones and siltstones. The upper layers (succession 4; 249-245.1 m) consist of fine-grained and very fine-grained sandstone, siltstone and claystone, with palaeosols and plant fragments. They were deposited in a meandering/ anastomosing river system (channel fill/point bars - distributary channels, floodplains). The uppermost deposits of this succession probably were eroded. The latest terrestrial succession 5 (245.1$244.0 \mathrm{~m}$ ) is connected with sedimentation in the channel fill, and the deposits contain numerous intercalations with plant remains within grey fine-grained sandstone (Pieńkowski 2014).

The overlying part of the Jurassic section $(234.5-244.5 \mathrm{~m})$ is represented by carbonate marine sediments of Callovian, Oxfordian and lower Kimmeridgian ages (Matyja \& Ziółkowski 2014).

Due to the absence of index fossils, the stratigraphic position of the siliciclastic terrestrial part of Cianowice 2 could not be determined. Based on tentative lithological comparisons, its possible age has been suggested to be Early (Pieńkowski 2014) or Middle Jurassic (Matyja \& Ziółkowski 2014). So far there were no fossil data that could confirm the exact age of these deposits.

\section{MATERIAL AND METHODS}

The studied plant remains come from a core section (265.5$244.5 \mathrm{~m}$ depth) from the Cianowice 2 borehole. All rock fragments yielding plant fossils were picked out from the core. The maximum size of the fossils was restricted by the core diameter $(70 \mathrm{~mm})$. The examined macroflora is represented by 27 core fragments (here referred to as hand specimens), often covered with undeterminable plant debris; 96 plant fragments were preserved well enough to enable identification of taxa. The best-preserved fossils are cycadophyte pinnae fragments. Seed ferns are preserved mostly as separate pinnules; Pseudotorellia Florin or conifers are represented by separate leaves or leaf fragments, often without apex and base, or small parts of leafy shoots. Some detached Cycadolepis Saporta scales were also found. Ninety-six plant fragments were usable for taxonomic determination, preserved as compressions with relatively good cuticles or as impressions with visible morphological details.

The hand specimens are stored in the palaeobotanical collection of the W. Szafer Institute of Botany, Polish Academy of Sciences, Cracow, and are labelled KRAM P 141 (the locality number), followed by the specimen number and plant fragment number. When the leaf fragments were small and were used to make a whole-fragment preparation, the slide number is given.

The pieces of cuticle were prepared in the standard way in Schulze's reagent $\left(\mathrm{KClO}_{3}+\mathrm{HNO}_{3}\right)$ and washed in $3 \% \mathrm{KOH}$ (Schulze 1855). They were examined by light microscopy. The macro photographs were taken under cross-polarized light.

Palynological samples were taken along the same section as the macroflora, but with additional sampling from both ends of the section $(245.30 \mathrm{~m}, 264.18 \mathrm{~m}, 264.20 \mathrm{~m})$. They were not taken from exactly the same core fragments as the macroremains because that would destroy the plant remains, which are crowded in the core sections, but represent the same lithological and sedimentological features. Twenty-six palynological samples were obtained. Thirteen samples did not contain sporomorphs, and in eight samples the number of sporomorphs was very low. The preservation of most fern spores and bisaccate pollen grains is very poor. They are so damaged that their diagnostic characters are not observable. Since identification at species level was not possible in most cases, some are determined at morphological group level and some are mentioned only as bisaccate pollen grains because they do not show surface details needed for closer determination. This paper does not include systematic descriptions of sporomorphs but they are listed in the Appendix 1 (from levels containing sporomorphs) together with quantitative data and are discussed in the palaeoenvironmental context.

Samples for sporomorph analysis were prepared by standard palynological techniques with $38 \% \mathrm{HCl}, 40 \% \mathrm{HF}$, Schulze's reagent and $10 \% \mathrm{KOH}$, and sieved (if needed) through $250 \mu \mathrm{m}$ and $15 \mu \mathrm{m}$ sieves (with ultrasonic treatment). Glycerine-gelatine jelly was used as mounting medium. Two slides were made from each sample. Number of sporomorphs per slide was calculated as the average of two slides (Appendix 1; Fig. 5). The slides were examined under a Carl Zeiss Axio Scope. Appendix 1 transmitted light microscope, which was also used to take microphotographs. Microphotographs were taken with the use of an AxioCam ICc 5 camera and Zeiss A-Plan 100×/1.25 oil-immersion objective.

\section{SYSTEMATIC PALEONTOLOGY}

\section{Family OSMUNDACEAE Martinov, 1920 Genus Cladophlebis Brongniart, 1849}

$$
\text { ?Cladophlebis sp. }
$$$$
\text { (Fig. 3A, B) }
$$

Material. - Two small frond fragments (12 $\mathrm{mm}$ and $7 \mathrm{~mm}$ long) on two hand specimens, very poorly preserved, incomplete pinnules with barely visible venation.

HAND SPECIMENS. - KRAM P 141/2, 141/9/II/G. 
AgE RANGE. - The genus Cladophlebis is known from the Triassic to the Cretaceous.

OCCURRENCE. - Widespread, mainly in the Jurassic of the Northern Hemisphere.

\section{DESCRIPTION}

One fragment showing rachis with two incomplete pinnules, rachis $0.5-1.6 \mathrm{~mm}$ wide, pinnules $c .6 \mathrm{~mm}$ long and $-4 \mathrm{~mm}$ wide, with prominent midrib and with veins forking once. Distance between veins $1.3 \mathrm{~mm}$. Veins dichotomizing at $1 / 3$ of their total length. Other characters not preserved.

\section{REMARKS}

The fragments are very small, the pinnules are incomplete, and details are poorly preserved. The pinnules resemble mostly those of Cladophlebis in shape, base or venation, but are significantly smaller than is usual in this genus, being rather more in the range of Todites princeps (Presl) Gothan. As the venation does not seem to fit the T. princeps type, we classified these small samples as ?Cladophlebis sp. to indicate the uncertainty of their taxonomic affinity.

Family PTERIDOSPERMAE incertae sedis Genus Pachypteris Brongniart emend. Harris (1964)

Pachypteris rhomboidalis (Ettingshausen) Nathorst (Fig. 3C-E)

Öfversigt af Kongl. Vetenskaps-akademiens forhandlingar 37 (5): 84 (Nathorst 1880). - Thinnfeldia rhomboidalis Ettingshausen, Abhandlungen der K. K. geologischen Reichsanstalt 1 (3): 2-4, pl. 1, figs 4-7 (Ettingshausen 1852). - Type: Romania, Thinnfeld Pit, in Steierdorf, Anina. Lectotype Ettingshausen, 1852, pl. 1, fig. 5, designated by Doludenko 1974.

Thinnfeldia rhomboidalis Ettingshausen, Abhandlungen der K. K. geologischen Reichsanstalt 1 (3): 2-4, pl. 1, figs 4-7 (Ettingshausen 1852). - Pachypteris thinnfeldi Andrae, Abhandlungen der K. K. geologischen Reichsanstalt III (4): 43-44, pl. 11, fig. 6; pl. 12, figs. 7-9 (Andrae 1855). - Pachypteris rhomboidalis (Ettingshausen) Doludenko, Birbal Sahni Institute of Palaeobotany Special Publication 2: 103, pl. 12, figs 1-6 (Doludenko 1974); Acta Palaeontologica Romaniae 81-87, pl. 1, figs 3, 4; pl. 2, fig. 6; text fig. 4 (Popa 1997b).

MATERIAL. - One leaf fragment with four pairs of pinnae and apical pinna, and eight separate pinnae (mostly apical), with well-preserved cuticles. One separate piece of cuticle was prepared from debris.

HAND SPECIMENS. - KRAM P 141/5/5, 141/5/BM, 141/6/I, 141/6/I/CC, 141/9/II/B, 141/10/II/CB, 141/12/14, 141/17/4, 141/32/4, Cia/I/32 (cuticle only).

Age RAnge. - Late Triassic to Jurassic.

OCCURRENCE. - Widespread in the Jurassic, mainly in the Northern Hemisphere.

\section{DESCRIPTION}

The most complete specimen is an apical leaf fragment $65 \mathrm{~mm}$ long, with 9 pinnae. Rachis $1 \mathrm{~mm}$ wide (Fig. 3C). Pinnae alternately inserted, oval, with entire margins and rounded apex. Pinnae joining rachis along their whole width, base slightly decurrent, pinnae $22 \times 8.5 \mathrm{~mm}$ at lowest part of fragment to $14 \times 6 \mathrm{~mm}$ near apex. Apical pinnae (including separate ones) generally oval/rectangular but margins irregularly undulate, up to $20 \mathrm{~mm}$ long and 6-11 mm wide. Venation visible in some parts of pinnae, with thin but wellvisible midrib and slightly arched, forking lateral veins running to margins. Leaves amphistomatic, with rather thick cuticle. Cell outlines irregular, cell walls straight, similar on both cuticles (Fig. 3D, E).

Upper cuticle much thicker than lower one, stomata sporadic on upper cuticle, densely scattered on whole blade on lower cuticle. Subsidiary cells (5-7) form thickened rings around stomatal pit, encircling cells commonly present. Guard cells thin and usually destroyed during maceration.

\section{REMARKS}

Since the family Umkomasiaceae Petriella is considered to be restricted to the Southern Hemisphere according to the newest revision (Anderson et al. 2019), we feel justified in labelling the family affiliation of Pachypteris rhomboidalis as incertae sedis. Describing Pteroma thomasii as a microsporophyll probably belonging to Pachypteris, Harris (1964) suggested an attribution of Pachypteris different from Umkomasiaceae (with microsporophyll Pteruchus). So far, the female organ that could be attributed to Pachypteris is unknown.

The remains from Cianowice closely resemble Pachypteris rhomboidalis in pinna shape and size, the variable margins, venation, and cuticular structure. $P$. rhomboidalis has been mentioned from Poland from the Early or Middle? Jurassic of the Lublin Coal Basin (Szydeł \& Szydeł 1981).

\section{Genus Ptilozamites Nathorst, 1878b}

\section{Ptilozamites cycadea (Berger) Möller}

(Fig. 3F-H)

Kungliga Svenska Vetenskapsakademiens Handlingar 36 (6): 19-20 (Möller 1902). - Odontopteris cycadea Berger, Die Versteinerungen der Fischer und Pflanzen im Sandsteine der Coburger Gegend: 23, 27, pl. 3, figs 2, 3 (Berger 1832). - Type: Germany, Coburg region, Rhaeto-Liassic lectotype designed by Harris (1964): specimen figured by Berger (1832: pl 3, fig. 2).

Ctenozamites cycadea (Berger) Schenk, Bibliotheca Botanica Stuttgart 6: 5, pl. 3, fig. 11-16a; pl. 4, fig. 18; pl. 6, fig. 30; pl. 7. fig. 36; pl. 8, fig. 43; pl. 9, fig. 54 (Schenk 1887); The Yorkshire Jurassic flora. II. Caytoniales, Cycadales \& Pteridosperms: 95-99, pl. 4, figs 3, 7; text-figs 41, 42 (with synonymy) (Harris 1964); Proceedings $4^{\text {th }}$ European Palaeobotanical and Palynological Conference. Mededelingen Nederlands Instituut Toegepaste Geowetenschappen TNO 58: 82, figs 1-9, text fig. 1 (with synonymy) (Barbacka 1997).

MATERIAL. - One small fragment of compressed pinna with 6 pinnules, separated from matrix.

HAND SPECIMEN. - KRAM P 141/1.

Age Range. - Late Rhaetian to Middle Jurassic. 

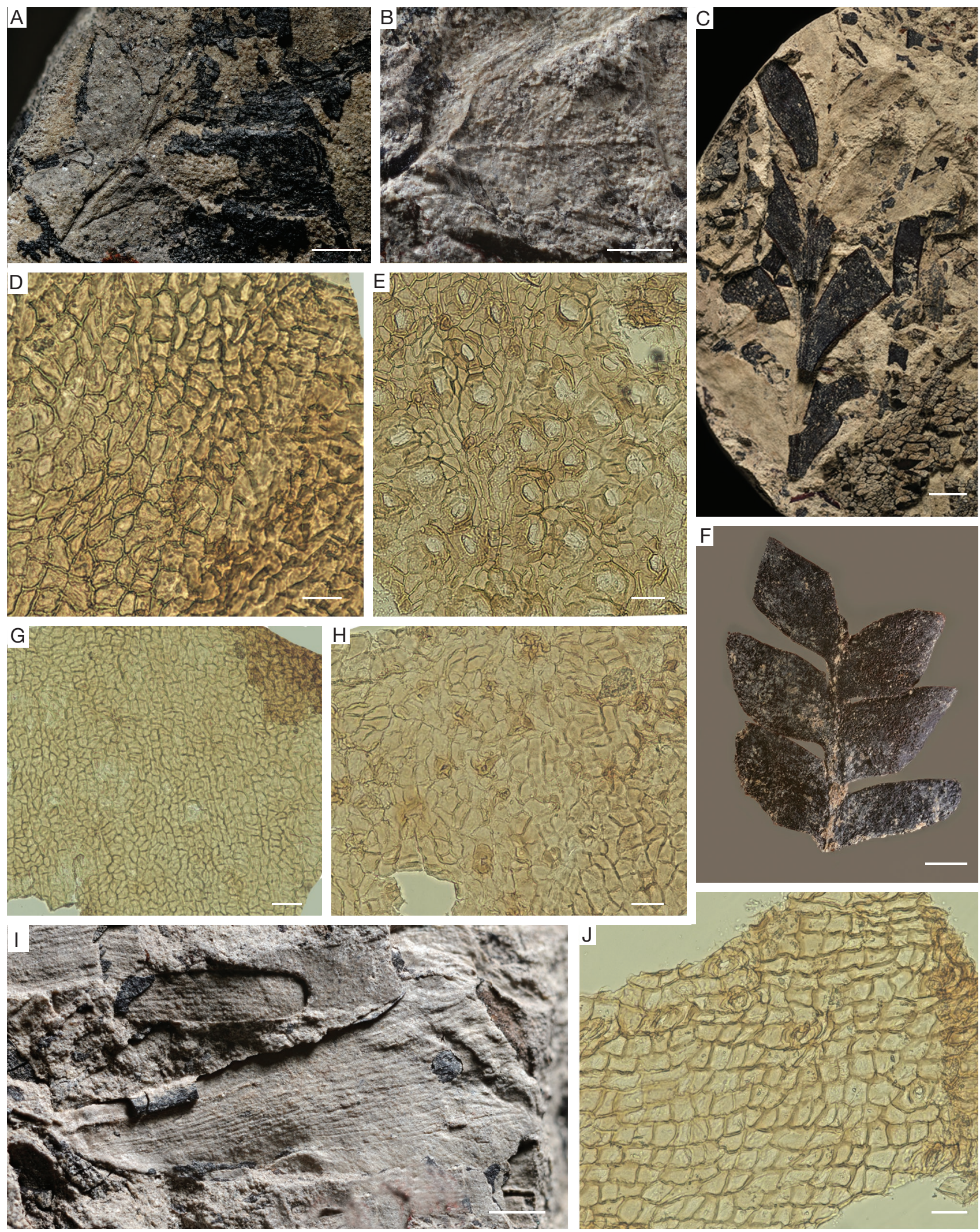

FIG. 3. - A, ?Cladophlebis sp. (no. 141-2-CA); B, ?Cladophlebis sp. (no. 141-9-II G); C, Pachypteris rhomboidalis (Ettingshausen) Nathorst (no. 141-10-II); D, Pachypteris rhomboidalis upper cuticle (slide no. 141/10/S/22); E, Pachypteris rhomboidalis lower cuticle (slide no. 121/10/S/22); F, Ptilozamites cycadea (Berger) Moller (no. 141-1); G. Ptilozamites cycadea upper cuticle (slide no. 141/01/S/2); H. Ptilozamites cycadea lower cuticle (slide no. 141/01/S/2); I, Ctenis sp. (no 141-10-BD); J, Ctenis sp. lower cuticle (slide no. 141/10/S/5). Scale bars: A, B, F, I, 2 mm; C, 5 mm; D, E, H, J, 50 rm; G, $100 \mu m$. 
OCCURRENCE. - United Kingdom (Yorkshire), Germany, Hungary, Romania, France, Sweden, Switzerland, Poland (this paper).

\section{DESCRIPTION}

Pinna fragment $13 \mathrm{~mm}$ wide, rachis $1 \mathrm{~mm}$ wide. Pinnules alternate, $7 \mathrm{~mm}$ long and $4 \mathrm{~mm}$ wide, rhomboid, with obtuse apex and entire margins. Base (Fig. 3F) as wide as segment, sometimes slightly decurrent. Veins not visible, due to poor preservation. Leaf hypostomatic. Cuticle (Fig. 3G, H) of medium thickness, cell outlines irregular, stomata on lower cuticle scattered, consisting of 5-7 large subsidiary cells around small stomatal pit and forming small thickened ring above guard cells. On lower cuticle, small one-celled trichome bases present, as well as multicellular trichome bases consisting of mostly 6 radially arranged cells forming central rounded, star-shaped or irregular thickening with cavity.

\section{REMARKS}

The attribution of the former Ctenozamites Nathorst, 1886 to Ptilozamites Nathorst, 1878 was proposed by some authors (Popa \& McElvain 2009; Van Konijnenburg-van Cittert 2018), but the first to use the combination Ptilozamites cycadea was Möller (1902). The fragment is small and no details of venation are visible, but the pinnule shape is characteristic for Ptilozamites. It is somewhat smaller than usually described (e.g. Harris 1964; Barbacka 1997) but fits within its variability. The cuticle is typical for Ptilozamites cycadea, with characteristic stomata and trichome bases (Harris 1961; Barbacka 1997).

\section{Division CYCADOPHYTA Bessey, 1907 Order CYCADALES Persoon ex Berchtold \& Presl 1820}

\section{Ctenis sp.}

(Figs 3I, J; 4A)

MATERIAL. - One specimen, on which one fragment of a pinna is preserved, mainly as an imprint but with a small piece of cuticle.

HAND SPECIMEN. - KRAM P 141/10/BD.

\section{DESCRIPTION}

Pinna fragment $17.4 \mathrm{~mm}$ long and $6 \mathrm{~mm}$ wide at base, shape unclear due to poor preservation. Veins running parallel and anastomosing to form loose meshes. Cuticle (Fig 3I) of moderate thickness, commonly showing nearly square cells tending to form short rows. Cell outlines thick and straight. Stomata occurring on lower cuticle, sparsely scattered, orientation unknown because cuticle fragment too small. Subsidiary cells 5-6, surrounding well-cutinized, large guard cells (Fig 3J; 4A).

\section{REMARK}

This taxon is very difficult to determine since the pinna is very fragmentary. Only the details of venation, with anastomoses, qualify the fossil as Ctenis sp.
Order BENNETTITALES Engler, 1892

Genus Anomozamites Schimper emend Harris, 1969

\author{
Anomozamites nilssonii (Phillips) \\ Seward emend. Harris
}

(Fig. 4B-D )

The Yorkshire Jurassic flora. III. Bennettitales: 79-83; text-figs 37, 38 (with synonymy) (Harris 1969). - Aspleniopteris Nilsoni Phillips, Illustrations of the geology of Yorkshire, or, a description of the strata and organic remains of the Yorkshire Coast: Accompanied by a geological map, sections, and plates of the fossil plants and animals: 147, pl. 8, fig 4 (Phillips 1829). - Anomozamites Nilssoni (Phillips) Seward, The Jurassic flora I. The Yorkshire coast. Catalogue of the Mesozoic Plants in the Department of Geology: 204; text-fig. 36 (Seward 1900); Jurassic continental deposits of the Middle-Caspian Basin. 2: Facies, taphonomy, interregional correlations, flora (Pinophyta: Pteridospermae, Cycadales, Bennettitales, Ginkgoales, Czekanowskiales, Coniferales): 58, pl. 13, figs 1-12; pl. 14, figs 1-13; pl. 15, figs 1-14 (Kiritchkova \& Nosova 2012). - Type: Great Britain, Middle Jurassic, Gristhorpe Bed, holotype designated by Seward (1900): specimen illustrated on pl. 8, fig. 4 (Philips 1829), York Museum.

MATERial. - Four leaf fragments on one specimen, all without base and apex, impressions with small cuticle pieces.

HAND SPECIMENS. — KRAM P 141/15/I/BK, 141/15/I/BL, 141/15/I/ BW, 141/15/I/BZ.

AgE RANGE. - Middle Jurassic.

Occurrence. - United Kingdom (Yorkshire), Russia (Middle Caspian Basin), Korea, Poland (this paper).

\section{DESCRIPTION}

Leaves 9-12.3 mm wide. Midrib smooth, $1.2 \mathrm{~mm}$ wide, leaf blade deeply divided (to midrib) into alternate rectangular segments $c$. $6 \mathrm{~mm}$ long and 7.2-9.2 mm wide (Fig. 4B). Size of segments decreasing toward base. Veins running nearly parallel from rachis to margin, forking at least once (poor preservation). Segment margins entire. Leaf hypostomatic. On upper cuticle, cell outlines rectangular to irregular, deeply sinusoid, one-celled hair bases. On lower cuticle, cell outlines more irregular than on upper cuticle, and sinuses not so deep. Stomata oriented irregularly but often transversely. Trichome bases rare, adjacent to stomata (Fig. 4C, D).

\section{REMARKS}

The gross morphology generally agrees with that of small specimens described by Harris as A. nilssonii (Harris 1969) from the Middle Jurassic of Yorkshire (or the basal part of a normal-size leaf) and with specimens from the Early and Middle Jurassic of the Middle Caspian Basin (Kiritchkova \& Nosova 2012). The proportions of the segments from Cianowice fit the variability of the species, corresponding well to specimens from Russia (Kiritchkova \& Nosova 2012, pl. 14, figs 6-8). The small pieces of cuticle show features very similar to those from Yorkshire and Russia. Although the specimens are too small to show all the known characters, we assign the specimens from Cianowice to this species. 

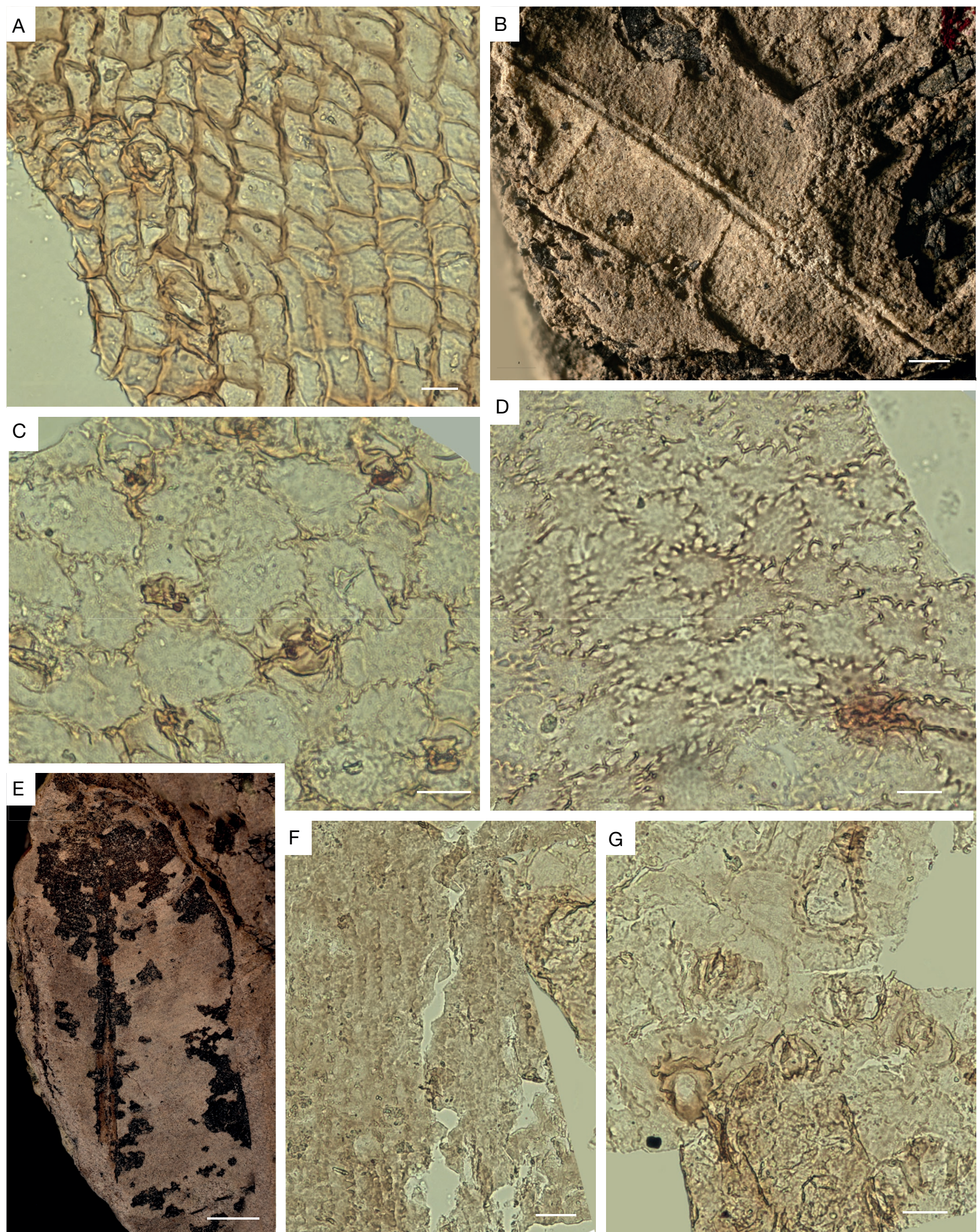

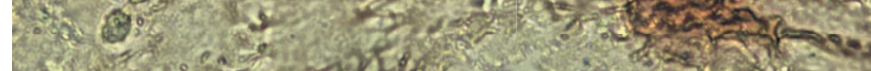

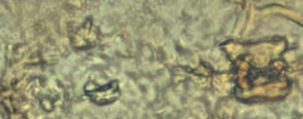
Ateres

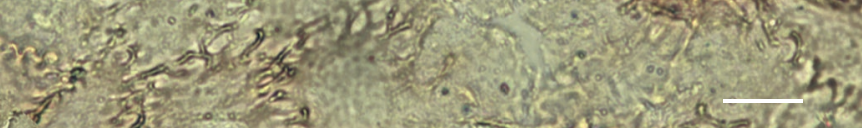
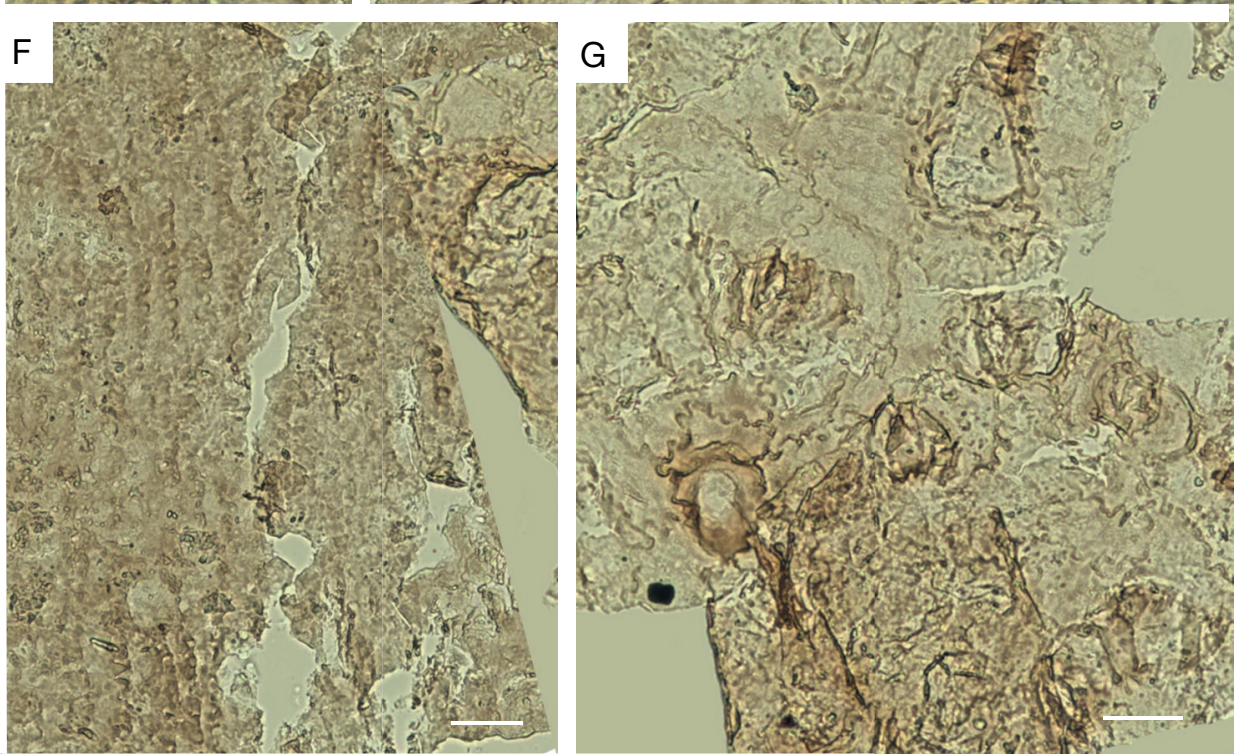

FIG. 4. - A, Ctenis sp. lower cuticle, stomata (slide no. 141/10/S/5); B, Anomozamites nilssonii (Phillips) Seward emend. Harris (no. 141-15-I-BK); C, Anomozamites nilssonii lower cuticle with stomata (slide no. 141/15/I/S/5); D, Anomozamites nilssonii upper cuticle with one-cell hair bases (slide no. 141/15/I/S/5); E, Nilssoniopteris solitaria (Phillips) Cleal \& Rees (no. 141/15/I); F, Nilssoniopteris solitaria upper cuticle (slide no. 141/15/I/S/16); G, Nilssoniopteris solitaria lower cuticle with stomata and hair cell (slide no. 141/15/l/S/16). Scale bars: A, C, D, $25 \mu \mathrm{m} ; \mathrm{B}, 2 \mathrm{~mm}$; E, 5 mm; F, G, $50 \mu \mathrm{m}$. 
Genus Nilssoniopteris Nathorst, 1909

\section{Nilssoniopteris solitaria (Phillips) Cleal \& Rees}

(Fig. 4E-G)

Palaeontology 46 (4): 764 (Cleal \& Rees 2003). - Scolopendrium solitarium Phillips, Illustrations of the geology of Yorkshire, or, a description of the strata and organic remains of the Yorkshire Coast: Accompanied by a geological map, sections, and plates of the fossil plants and animals: 147/153, pl. 8, fig. 5 (Phillips 1829). - Type: Great Britain, White Nab near Scarborough (Yorkshire), Gristhorpe Member, Cloughton Formation, Bajocian, Middle Jurassic, type specimen: OUMNH J.29628 stored at the Museum of Natural History Oxford University United Kingdom, designated by Pott \& Van Konijnenburg-van Cittert (2017): 180, pl. 1, figs 1-5.

MATERIAL. - One leaf fragment with apex, without base, preserved as impression, some parts with cuticle.

HAND SPECIMEN. - KRAM P 141/15/I.

AgE RANGE. - Early to Middle Jurassic.

OCCURRENCE. - Greenland, Bornholm, United Kingdom (Yorkshire, Stonesfield), Switzerland, Poland (Lublin area, Cianowice, this paper).

\section{DESCRIPTION}

Leaf entire, linear-lanceolate. Midrib strong, $1.5 \mathrm{~mm}$ wide, whole lamina $20 \mathrm{~mm}$ wide. Apex obtuse, margin entire, veins parallel and arising at almost $90^{\circ}$, sometimes bifurcating (Fig. 4E), their density 22 veins $/ \mathrm{cm}$. Leaf hypostomatic. Upper cuticle thicker than lower, cell outlines rectangular to polygonal, cell walls sinusoid. Cell outlines more irregular in lower cuticle than upper, stomata of syndetocheilic type, trichome bases present (Fig. 4F, G).

\section{REMARKS}

The taxonomy of this species was thoroughly discussed by Cleal \& Rees (2003), Cleal et al. (2006), Pott \& McLoughlin (2009) and Van Konijnenburg-van Cittert et al. (2017). Pott \& Van Konijnenburg-van Cittert (2017) provided a full synonymy and diagnosis of Nilssoniopteris solitaria. The specimen from Cianowice, according to the shape, vein density, and cuticular structure, corresponds with $N$. solitaria although the small fragments of cuticle are not enough for a full comparison with the type material. Nilssoniopteris vittata, now included in $N$. solitaria (Pott \& Van Konijnenburg-van Cittert 2017), was mentioned from Poland from the Early Jurassic of the Lublin Coal Basin (Szydeł \& Szydeł 1981).

\section{Genus Otozamites Braun, 1842}

\section{Otozamites mimetes Harris} (Fig. 5A-D)

Annals and Magazine of Natural History, London 12 (2): 285, figs 3B, C, 5 (Harris 1949); Harris, The Yorkshire Jurassic flora. III. Bennettitales: 41, text fig. 18A-G. (Harris 1969). — Type: Great Britain, Yorkshire, Middle Jurassic, holotype designated by Harris (1969): specimen in Yorkshire Museum, figured by Harris (1949: figs 3B, C, 5) (Harris 1969).
MATERIAL. - Three leaf fragments, the larger one with five pairs of pinnae, all preserved as compressions.

HAND SPECIMENS. — KRAM P 141/6/II/7, 141/6/II/AD, 141/18/U.

AGE RANGE. - Early to Middle Jurassic.

OcCurrence. - United States (Alaska), United Kingdom (Yorkshire), Poland (this paper).

\section{DESCRIPTION}

Leaf pinnate, $23 \mathrm{~mm}$ wide. Pinnae alternate to subopposite, c. $11 \mathrm{~mm}$ long and 5.4-6.5 mm wide, slightly curved upwards. Auricle very feebly developed, basal margin slightly contracted. Veins very thin, arising from whole base except auricle, nearly parallel. Apex obtuse (Fig. 5A). Leaf hypostomatic. Upper and lower cuticles of equal thickness. On upper cuticle, cell outlines mostly rectangular, tending to form rows. Walls deeply sinusoid (Fig. 5D). On lower cuticle cells more irregular, cell walls strongly sinusoid, most cells showing central papilla. Papillae on cells near stomata may overhang stomatal pit. Stomata irregularly spaced, in some cases forming short rows, oriented transversely to veins (Fig. 5B, C).

\section{REMARK}

The leaf fragment from Cianowice closely corresponds to the material from Yorkshire reported by Harris (1969), who, besides giving a description, discussed the taxonomic position of his specimens; we follow his opinion. The material is also similar to Otozamites mimetes from Alaska (Barbacka et al. 2006).

\section{Otozamites parallelus Phillips}

(Fig. 5E-H)

Illustrations of the geology of Yorkshire, or, a description of the strata and organic remains. Part I, The Yorkshire Coast. 221, fig. 47 (Phillips 1875). - Type: Great Britain, Yorkshire, Middle Jurassic, holotype designated by Harris (1969): specimen figured by Phillips (1875: 221, fig. 47) (Harris 1969).

MATERIAL. - Seven leaf fragments from the middle part, the most complete of which shows eight pairs of pinnae. They are impressions or compressions, with poorly preserved cuticles.

HAND SPECIMENS. - KRAM P 141/2/I/2, 141/2/I/4, 141/6/2, 141/6/I/6,141/9/II/CD, 141/20/F, 141/31/5.

AgE RANGE. — Middle Jurassic

OCCURRENCE. — United Kingdom (Yorkshire), Poland (this paper).

\section{DESCRIPTION}

Leaf pinnate, $c .13 .5 \mathrm{~mm}$ wide. Pinnae 6-9.6 $\mathrm{mm}$ long and 3.3-4.6 mm wide, alternate, crowded and overlapping the 0.6-1 mm wide rachis. Pinna apex obtuse, base with small but distinct acroscopic auricle, basal margin slightly constricted. Veins forking, running from lower $1 / 3$ of pinna base slightly radially, in auricle closer to rachis (Fig. 5E, F). Leaf hypostomatic. Upper and lower cuticles of equal thickness. On upper cuticle, cell outlines rectangular to polygonal, rectangular ones tending to form short rows (above veins?). 

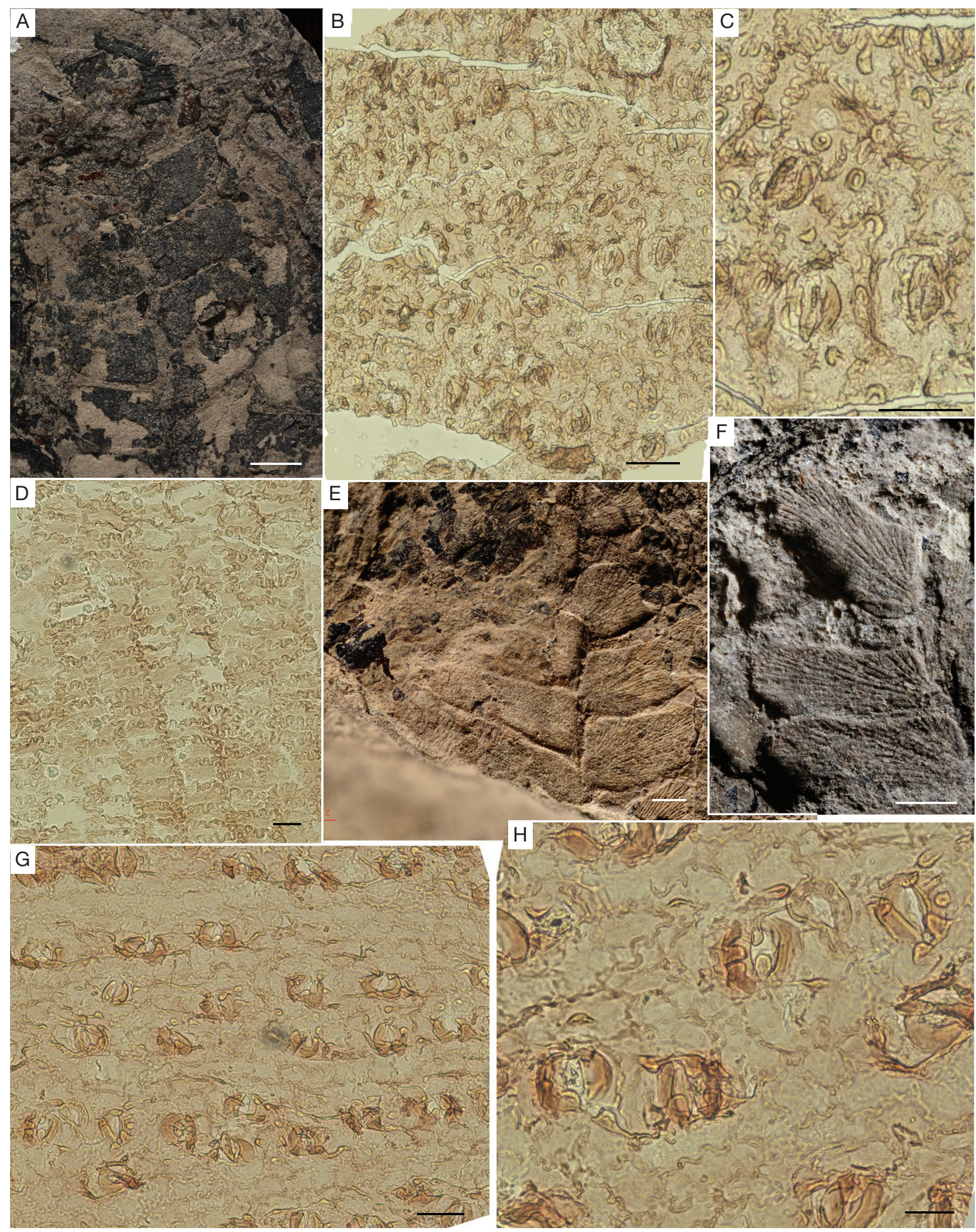

FIG. 5. - A, Otozamites mimetes Harris (no. 141-6-II-7); B, Otozamites mimetes lower cuticle (slide no. 141/06/ll/S/15); C, Otozamites mimetes lower cuticle, stomata (slide no. 141/06/II/S/15); D, Otozamites mimetes upper cuticle (slide no. 141/06/II/S/15); E, Otozamites parallelus Philips (no. 141-6-I-6); F, Otozamites parallelus details of pinnae (no. 141-9-II-CD); G, Otozamites parallelus lower cuticle (slide no. 141/06/II/S/6); H, Otozamites paralle/us lower cuticle with details of

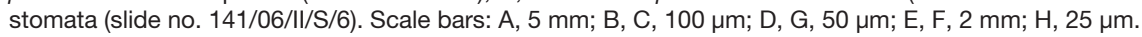


On lower cuticle, cells irregular but along veins may be elongated. Stomata distributed between veins in two quite irregular rows, oriented transversely, syndetocheilic. Papillae present on lower cuticle, at different densities depending on the specimen (Fig. 5G, H ).

\section{REMARK}

This species is known only from Yorkshire, where it occurs relatively rarely (Harris 1969). In Cianowice, O. parallelus is one of the commonest species. These leaf fragments correspond with Harris's material in the whole complement of macro- and micromorphological features, although Harris's specimens lacked the upper cuticle. In Cianowice, the upper cuticle was found as an exception, recognised on only one leaf fragment.

\section{Genus Pterophyllum Brongniart, 1828}

\section{Pterophyllum thomasii Harris} (Fig. 6A-D)

Annals and Magazine of Natural History, London 12 (5): 93, text figs 43A-E, 44A-H (Harris 1952). — Type: Great Britain, Yorkshire, Middle Jurassic, holotype designated by Harris (1969): Lackenby Colln. no. 222, Sedgwick Museum, Cambridge (Harris 1969).

MATERIAL. - Six leaf fragments, all from middle part. One larger fragment has 12 pairs of pinnae; two others have eight and five incomplete pairs of pinnae, and the rest are more fragmented. Some are very poorly preserved but the cuticle of all specimens is of the same type.

HAND SPECIMENS. - KRAM P 141/9/I /AT, 141/15/I/BJ, 141/17/2, 141/18/W2, 141/21/Y, 141/22/AC.

Age RANGE. - Middle Jurassic, to Early Cretaceous.

Occurrence. - United Kingdom (Yorkshire), Spain, Poland (this paper).

DESCRIPTION. - Leaf pinnate, with largest pinnae in central leaf portion. Pinnae 4.7-20 mm long and 1.5-3 mm wide. Rachis finely wrinkled, $1 \mathrm{~mm}$ wide. Pinnae crowded or separated; bases slightly expanded, and in contact, veins thin, parallel (Fig. 6A). Leaf hypostomatic. Lower and upper cuticles of equal thickness. On upper cuticle, cell outlines mostly square, tending to form short rows, veins not indicated (Fig. 6B). Cell walls strongly sinusoid. On lower cuticle, cell outlines square to polygonal, more regularly square above veins. Syndetocheilic stomata distributed in wide strips between veins, rather irregularly oriented (Fig. 6C, D).

\section{REMARK}

All features of the described material correspond closely to the description of Pterophyllum thomasii from Yorkshire. The specimens from Cianowice fit within the size range of the specimens from Yorkshire.

\section{Pterophyllum cf. aequale (Brongniart) Nathorst, emend. Pott \& McLoughlin}

(Figs 6E, F; 7A)

Review of Palaeobotany and Palynology 158 (1-2): 125, pl. 2, figs 1-12; pl. 3, figs 1-8 (with synonymy) (Pott \& McLoughlin 2009). - Pte- rophyllum aequale Nathorst, Sveriges Geologiska Undersökning, Serie C 85: 18-19, 48-49; pl. 2, fig. 13; pl. 6, figs 8-1 (Nathorst 1878a). Nilssonia? aequalis Brongniart, Annales des Sciences Naturelles 4: 219, pl. 12, fig. 6 (Brongniart 1825). - Type: Holotype designated by Pott \& McLoughlin (2009): specimen figured by Brongniart (1825: pl. 12, fig. 6). The specimen was probably stored in the collections of the Musée d'Histoire Naturelle, Paris, France. Lectotype: LO $327 \mathrm{t} /$ S065864 (figured by Nathorst 1878c: pl. 2, fig. 13), stored in the palaeobotanical collections of the GeoBiosphere Science Center, Lund University, Lund, Sweden. Cuticle fragment figured here in Pl. III, 8. Epitype: S054064 (figured by Lundblad 1950: pl. 9, fig. 8), stored in the palaeobotanical collections of the Swedish Museum of Natural History, Stockholm, Sweden (Pott \& McLoughlin 2009).

MATERIAL. - Eleven leaf fragments (one cuticle), all from middle part of leaf, preserved as compressions and impressions. Longest fragment has eleven pairs of pinnae.

HAND SPECIMENS. - KRAM P 141/4/I/4 = 141/4/II/4a (part and counterpart), 141/4/II/45, 141/4/III (4 fragments), 141/9/I/AL, 141/9/II/C, 141/10/10, 141/10/BA, 141/10/BC, 141/10/BG, 141/9/II/S/11 (cuticle only).

AgE RANGE. - Late Triassic to Early Jurassic.

OCCURRENCE. - Widespread, mainly in the Northern Hemisphere.

\section{DESCRIPTION}

Leaf pinnate, largest fragment c. $15 \mathrm{~mm}$ wide. Rachis $0.8 \mathrm{~mm}$ wide, smooth. Pinnae opposite, close to each other, often in contact, linear, with obtuse apex, up to $8 \mathrm{~mm}$ long and up to $2.5 \mathrm{~mm}$ wide. Pinna base straight, rarely slightly expanded, apex truncate. Veins very thin, barely visible, parallel, $c .7$ per pinna, bifurcation not visible due to poor preservation (Fig. 6E). Leaf hypostomatic, upper and lower cuticles of equal thickness. Upper cuticle showing square to polygonal cell outlines, rectangular at pinna margin (Fig. 6F). Cell walls straight. Cells on lower cuticle rectangular to polygonal, veins slightly marked by elongated cells, stomata scattered, oriented mostly transversely. Subsidiary cells usually bear papillae overhanging stomatal pit. Papillae on ordinary cells not observed (Fig. 7A).

\section{REMARK}

The leaf shape, pinna characters (shape, apex and arising angle) as well as cuticular structure are closest to $P$. aequale (Brongniart) Nathorst emend. Pott \& McLoughlin (Pott \& McLoughlin 2009; Pott et al. 2016), for which an emended diagnosis was given by Pott \& McLoughlin (2009). Especially the cell pattern and stomata with two opposite papillae are very peculiar, but there are some differences that make full identification difficult. The first is the size of the leaves, which are about half the typical size of this species. The number of veins is much lower than in the type material, in which up to 17 were counted in $1 \mathrm{~cm}$ (Pott \& McLoughlin 2009), or even 30 (Lundblad's specimens, described as separate species Pterophyllum compresum Lundblad (1950) and synonymized with P. aequale by Pott \& McLoughlin (2009)). Also, papillae are lacking on the cuticle of the specimens from Cianowice. The last difference is in age, which is typically Late Triassic and Early Jurassic; here it was together with typical Middle Jurassic species on the same specimen. Despite the above 



FIG. 6. - A, Pterophyllum thomasii Harris (no. 141-15 I BJ); B, Pterophyllum thomasii upper cuticle (slide no. 141/15///S/1); C, Pterophyllum thomasii lower cuticle (slide no. 141/15///S/1); D, Pterophyllum thomasii lower cuticle (slide no. 141/15///S/1); E, Pterophyllum cf. aequale (Brongniart) Nathorst emend. Pott \& McLoughlin

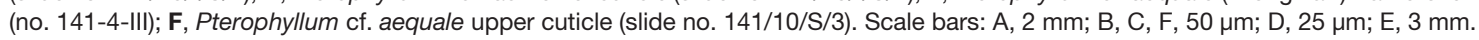


dissimilarities, we here determine the leaves from Cianowice as Pterophyllum cf. aequale based on the shape and arrangement of pinnae, as well as cell pattern and stomata structure as most important diagnostic characters distinguishing this species. The leaf size or number of veins (which also significantly varies between the specimens mentioned by Pott $\&$ McLoughlin (2009) and those of Lundblad (1950), and also the presence of papillae may vary highly depending on numerous ecological factors (authors' own observations). As for the difference in age, in our opinion it does not affect the determination (Kerp \& Pott pers. comm. 2018); thus, erection a new species is not justified in this case.

Genus Ptilophyllum Morris, 1840 emend. Harris, 1969

\section{Ptilophyllum cf. okribense forma ratchiana \\ Doludenko \& Svanidze \\ (Fig. 7B-E)}

International Geological Congress XXII Session Reports of Soviet Geologists Problem 9 Gondwana: 118, pl. 4 figs 1-12 (Doludenko \& Svanidze 1964). - Type: specimen No. 135/1 Georgia, Tkibuli, Middle Jurassic, Batonian, Ordzhonikidze coal mine.

MATERIAL. - Ten leaf fragments preserved as compressions and impressions, all from the middle part of the leaf. Largest one shows 23 pairs of pinnae and is $59 \mathrm{~mm}$ long.

HAND SPECIMENS. - KRAM P 141/4/II/21, 141/4/II/22, 141/9/I/9, 141/9/I/25, 141/9/II/A, 141/9/II/H, 141/10/11, 141/10/BB, $141 / 15 / \mathrm{I} / 24,141 / 15 / \mathrm{II} / 17$

AgE RANGE. — Middle Jurassic.

OCCURRENCE. — Georgia (Middle-Caspian Basin), Poland (this paper).

\section{DESCRIPTION}

Leaf pinnate, up to $12.4 \mathrm{~mm}$ wide. Pinnae alternate, attached to upper side of the rachis, elongated and commonly slightly curved upwards, up to $12 \mathrm{~mm}$ long and $2 \mathrm{~mm}$ wide. Pinnae usually in contact, rarely separate. Base asymmetric, basiscopic side decurrent, acroscopic side contracted. Apex truncate. Veins very fine, forking, c. 10 in middle of pinna (Fig. 7B). Leaf hypostomatic, upper and lower cuticles of equal thickness. Cells on upper cuticle mostly rectangular, tending to form short rows (Fig. 7C), cell walls strongly sinusoid. On lower cuticle, cell outlines similar but sometimes polygonal, sinuses strong but not as much as on upper cuticle. Stomata occurring in bands between usually 2 -cell-wide strips above veins. Stomatal bands varying in width: from 2-3 to 5-6 rows of stomata wide. Stomata oriented mainly transversely. Guard cells strongly cutinized; both subsidiary cells possessing a papilla overhanging the stomatal pit (Fig. 7D, E). One-celled hair bases sporadically present.

\section{REMARKS}

Generally the specimens from Cianowice correspond well with Pterophyllum okribense forma ratchiana (Doludenko \& Svanidze 1964). Both macro- and micromorphology are very similar, but in the material from Poland the arrangement of stomata (width of stomatal bands) is more varied (from typical to wider). Also, papillae are lacking in the Polish specimens, and hair bases occur only sporadically. We interpreted these deviations as natural variability conditioned by the environment. Nevertheless, we determined these specimens in the open nomenclature.

Ptilophyllum pecten Phillips emend. Harris, 1969

(Figs 7F, G; 8A)

The Yorkshire Jurassic flora. III. Bennettitales: 64-67, text figs 30, 31 (with synonymy) (Harris 1969); Annals and Magazine of Natural History: 117 (Morris 1841); Journal of Iberian Geology 35 (2): 132, fig. 6 (Diéguez et al. 2009). - Cycadites pecten Phillips, Illustrations of the geology of Yorkshire, or, a description of the strata and organic remains of the Yorkshire Coast: Accompanied by a geological map, sections, and plates of the fossil plants and animals: 168, pl. 7, fig. 22 (Phillips 1829). - Type: Great Britain, Yorkshire, Middle Jurassic, holotype Phillips (1829): pl. 7, fig. 22.

Material. - One specimen, fragment of leaf with 14 pairs of incomplete pinnae, $26 \mathrm{~mm}$ long. Preserved as impression of abaxial side of leaf with small fragments of cuticle.

HAND SPECIMEN. - KRAM P 141/21/Z.

AgE RANGE. - Middle Jurassic to Early Cretaceous.

OCCURREnCE. - United Kingdom (Yorkshire), Spain.

DESCRIPTION

Leaf pinnate, estimated width $11 \mathrm{~mm}$. Rachis $1 \mathrm{~mm}$ wide at the base of the fragment, narrowing to $0.5 \mathrm{~mm}$ towards leaf apex. Pinnae alternate, attached on the upper side of the rachis. Pinna length 4-5 mm, width 1.1-2 mm. Apex truncate, base not visible because impression shows lower side of the leaf (Fig. 7F). Only lower cuticle preserved. Cell outlines rectangular to irregularly polygonal, sinusoid. Each cell possessing large papilla. Stomata occurring between veins marked by more rectangular cells (two cells wide) in irregular rows 2-3 stomata wide and oriented transversely. Guard cells well cutinized, subsidiary cells possessing papillae overhanging stomatal pit (Figs 7G; 8A).

\section{REMARKS}

The species is distinctive for its very small size together with strongly papillate on the lower cuticle, stomata with crescent shaped guard cells and subsidiary cells bearing papillae. The characters of the Polish specimen agree with Ptilophyllum pecten (Phillips) Morris from Yorkshire (Harris 1969).

\section{Ptilophyllum sirkennethii Watson \& Sincock (Fig. 8B-E)}

Bennettitales of the English Wealden: 94, text figs 62A-C, 63A-G, 64A-D (Watson \& Sincock 1992). — Type: Great Britain, Ecclesbourne Glen, Hastings, E. Sassex, Early Cretaceous, Berriasian, holotype No V. 2227 British Museum (Natural History).

MATERIAL. - One leaf fragment $58 \mathrm{~mm}$ long with 13 pairs of pinnae. All pinnae incomplete, apices lacking. 

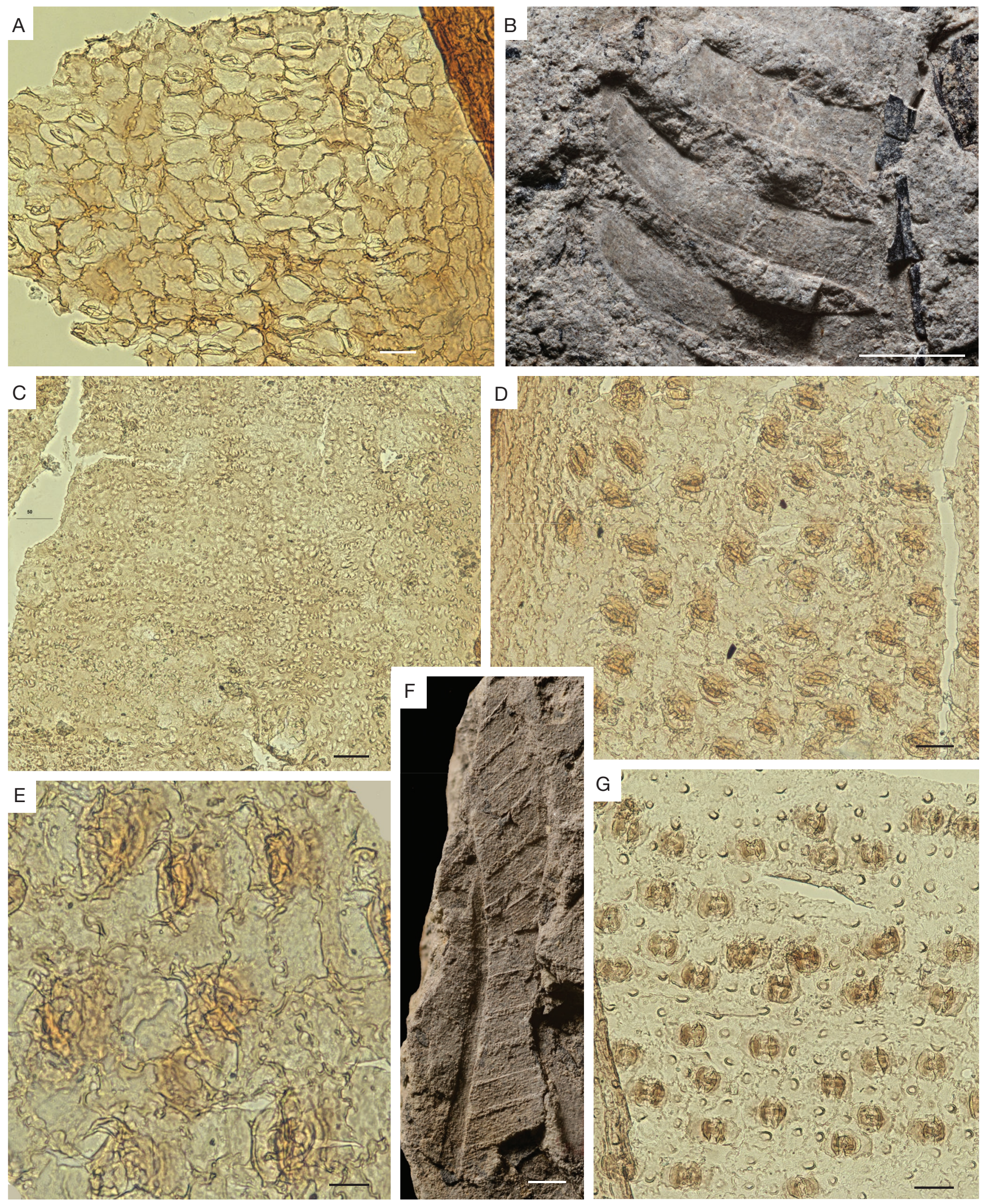

FIG. 7. - A, Pterophyllum cf. aequale (Brongniart) Nathorst, 1878a, emend. Pott \& McLoughlin, 2009, lower cuticle (slide no. 141/10/S/3); B, Ptilophyllum cf. okribense forma ratchiana Doludenko et Svanidze (no. 141-15 I 24); C, Ptilophyllum cf. okribense upper cuticle (slide no. 141/04/ll/S/6); D, Ptilophyllum cf. okribense lower cuticle (slide no. 141/04/II/S/6); E, Ptilophyllum cf. okribense lower cuticle with details of stomata (slide no. 141/04/ll/S/6); F, Ptilophyllum pecten

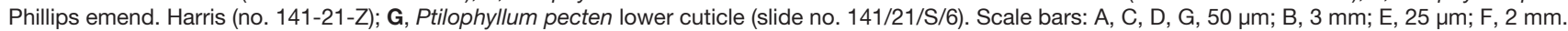


HAND SPECIMEN. — KRAM P 141/15/II/16.

Age RANGE. - Middle Jurassic-Early Cretaceous.

OCCURRENCE. — United Kingdom (Ecclesbourne Glen, Hastings), Poland (this paper).

\section{DESCRIPTION}

Leaf pinnate, $30 \mathrm{~mm}$ wide, with rachis $2.3 \mathrm{~mm}$ wide and alternate pinnae. Pinnae borne on upper surface of the rachis, lanceolate, with constricted acroscopic margin. Basiscopic margin decurrent, and apex subacute. Basal pinna $c .12 \mathrm{~mm}$ long (almost complete), longest complete pinna $14.4 \mathrm{~mm}$ long. Pinna width almost constant, $c .4 .4 \mathrm{~mm}$ at widest part. Venation fine, poorly visible due to coarse grain size of host rock. Veins slightly radiating from pinna base and seeming to divide, probably 8-12 per pinna (Fig. 8B). Leaf hypostomatic, cuticle moderately thick. Cell pattern similar on both upper and lower cuticles; cells isodiametric to rectangular, forming longitudinal files. Cell walls more strongly sinusoid on upper cuticle (Fig. 8C). On lower cuticle, stomata arranged in wide bands of $c .4$ longitudinal rows, separated by 2-3 cell-wide non-stomatal bands. Stomata transversely oriented, subsidiary cells large, each bearing a prominent papilla; both papillae meeting over stomatal pit (Fig. 8D, E).

\section{REMARK}

The leaf structure, especially pinna shape, base and venation, correspond well with Ptilophyllum sirkennethii described from the Lower Cretaceous of English Wealden by Watson \& Sincock (1992). The significant difference is in leaf size, being at least four times smaller than the English one, but the cuticular features entirely agree between the two materials. The cell pattern, stomata distribution and structure are the same. Since the species was established based on two specimens and we have only a single specimen, the possible size diversity within this taxon is unknown, but it is well known that leaf size is one of the most variable features in the genus. Because this is the only difference between the two materials, and numerous other species from this locality also show unusually small dimensions, we classify it as P. sirkennethii.

Genus Cycadolepis Saporta, 1874 emend. Harris, 1969

\section{Cycadolepis sp.}

(Fig. 8F, G)

MATERIAL. - Five bennettitalean cone scale specimens c. $20 \mathrm{~mm}$ long, preserved fragmentarily, mainly as compressions.

HAND SPECIMENS. - KRAM P 141/4/I/19, 141/4/I/43, 141/4/ II/41, 141/9/I/28, 141/16/18.

\section{DESCRIPTION}

Leaf scales small, probably spatulate, acroscopic part extended, up to $13 \mathrm{~mm}$ wide. Apex subacute. Veins thin, parallel, $c .10$ per $5 \mathrm{~mm}$. Forking not observed (Fig. 8F). Cuticle thick, cell walls straight. On adaxial (?) cuticle, cell outlines thick and square to rectangular, forming rows. Stomata lacking, or very sporadic if present. Cell pattern on abaxial (?) cuticle similar to that on adaxial side, but less regular. Syndetocheilic stomata frequent, scattered, oriented longitudinally (Fig. 8G).

\section{REMARK}

Since only fragments were found, their shape is not determinable. The cuticular features resemble mostly Cycadolepis hallei Harris, 1969 but the material is too fragmentary for a full comparison.

\section{Gymnospermae incertae sedis \\ Genus Pseudotorellia Florin, 1936}

Pseudotorellia grojecensis Reymanówna

(Figs 8H; 9A, B)

Acta Palaeobotanica 4 (2): 33-36, pl. 7, figs 1,3-5; text-figs 8A-K, 9 A-F (Reymanówna 1963b). — Type: Poland, Grojec clays, Middle Jurassic, Grojec near Krakow, Palaeobotanical collection KRAM P PM 53 in the National Biodiversity Collection - Herbarium KRAM at W. Szafer Institute of Botany, Polish Academy of Sciences, Palaeobotanical Collection KRAM P type specimen: KRAM P PM 53 hand specimen no. $49 \mathrm{~b}$ and slide from this specimen no. 79.

MATERIAL. - Six leaf fragments/groups of leaf fragments, all without base, only two apices preserved. Longest fragment $26.5 \mathrm{~mm}$ long. Preserved as compressions or impressions. Besides these, three cuticles were prepared from different specimens.

HAND SPECIMENS. — KRAM P 141/6/II/AF, 141/6/III/P, 141/9/I/27, 141/12/12 (4 fragments), 141/12/13 (debris), 141/32/1, 141/15/ II/S/1, 141/28/S/1, 141/28/S/II.

AgE RANGE. — Middle Jurassic.

OcCurrence. - Poland (Grojec, Cianowice, this paper).

\section{DESCRIPTION}

Leaves elongated, narrowing towards base and apex, margins parallel in middle part. Lamina 3.7-4.2 mm wide, apex narrowly obtuse or subacute (Fig. 8H). Veins parallel, c. 6-7 within leaf. Leaf hypostomatic. Upper cuticle thicker than lower, cell outlines square and trapezoid, sometimes triangular, arranged in rows, cell walls straight. Some cells thickened, forming unicellular hair base over vein. Cell outlines on lower cuticle more irregular between veins and rectangular over veins. Stomata occurring in strips (c. 12 stomata wide) between veins (c. 9 cells wide), oriented longitudinally. Stomata large, with large, well-cutinized guard cells. Subsidiary cells differ between lateral and terminal. Polar subsidiary cells small, rectangular, rarely triangular (Fig. 9A, B). Lateral cells mostly two (one on each side), narrow, but also often four (two each side), or three (two and one). In some cases encircling cells present. Between cuticles, longitudinal strands (fibres) present, easily moved or removed with a needle (ducts?).

\section{REMARK}

Originally Florin (1936) put Pseudotorellia among the ginkgophytes. Watson \& Harrison (1998) suggested that 

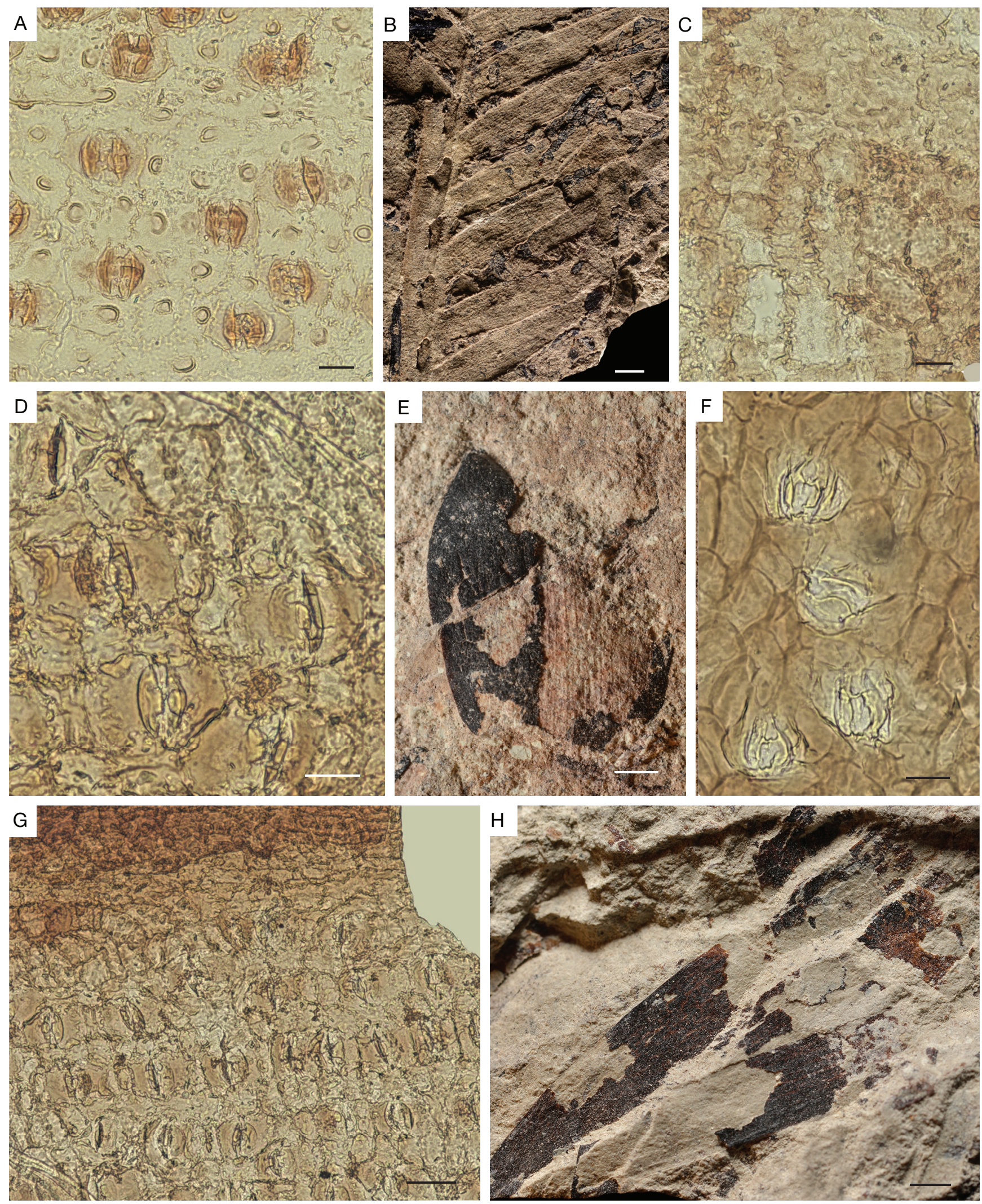

FIG. 8. - A, Ptilophyllum pecten Phillips, 1829 emend. Harris, lower cuticle (slide no. 141/21/S/6); B, Ptilophyllum sirkennethii Watson \& Sincock (no. 15-II-16); C, Ptilophyllum sirkennethii upper cuticle (slide no. 141/15/I/S/4); D, Ptilophyllum sirkennethii lower cuticle with details of stomata (slide no. 141/15/II/S/4); E, Ptilophyllum sirkennethii lower cuticle (slide no. 141/15/II/S/4); F, Cycadolepis sp. (no. 141-16-18); G, Cycadolepis sp. the cuticle (slide no. 141/16/S/1); H, Pseu-

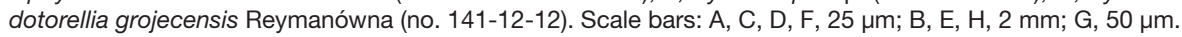


at least some species could be assigned to conifers based on their association and cuticular similarity with coniferalean shoots Sulcatocladus Watson \& Harrison, 1998. Dong et al. (2019) demonstrated that Umaltolepis yimaensis Dong, Zhou, Zhang, Wang \& Shi, ovules (which is not a typical ginkgoalean organ), and Pseudotorellia yinaensis Dong, Zhou, Zhang, Wang \& Shi belong to the same plant (Dong et al. 2019), but they do not exclude its ginkgophytalean affinity, rather stressing the group's diversity. Based on cuticular features and stomata structure Shi et al. (2018) linked Pseudotorellia with corystosperms, although the question of relationship was left to resolve later. Because of the above uncertainty, we treat Pseudotorellia as incertae sedis. The material from Cianowice corresponds well in all features (gross morphology, cuticular structure, presence of fibres) with the species erected by Reymanówna (1963b) from Grojec. Our determination is made more certain by the proximity of the two localities (Cianowice, Grojec); in Grojec this species is very common.

\section{Pseudotorellia samylinae Nosova \& Kiritchkova (Fig. 9C-E)}

Stratigraphy and Geological Correlation 17: 625, pl. 1, figs 15-17, 23-25; pl. 4, figs 1-14 (Kiritchkova \& Nosova 2009); Jurassic continental deposits of the Middle-Caspian Basin. 2: Facies, taphonomy, interregional correlations, flora (Pinophyta: Pteridospermae, Cycadales, Bennettitales, Ginkgoales, Czekanowskiales, Coniferales): 143, pl. 103, figs 15-17, 23-25; pl. 104, figs 1-14. - Type: Western Kazakhstan, Mangyshlak Peninsula, Chaga-Bulak Spring, lower member of the Kokala Formation; Lower Jurassic, Toarcian, holotype no. 757/1840-27, VNIGRI collection Botanical Institute, Russian Academy of Sciences, illustrated on plate I, fig. 15 (Kiritchkova \& Nosova 2009).

MATERIAL. - Three leaf fragments (but only small pieces from the middle part of the leaf preserved as compressions) and two pieces of cuticle.

HAND SPECIMENS. — KRAM P 141/6/II/8, 141/10/BE, 141/18/W, 141/20/S/4, 141/9/I/S/28.

AgE RANGE. - Early Jurassic (Toarcian) to Middle Jurassic.

Occurrence. - Eastern Caspian region, Poland (this paper).

\section{DESCRIPTION}

Leaf elongated, margins parallel, at least along 5-mm-wide middle part of leaf. Veins parallel, c. 5 per leaf, quite conspicuous (Fig. 9C). Upper and lower cuticles of equal thickness. On upper cuticle, cell outlines rectangular, elongated, cell walls straight, cells forming longitudinal rows. On lower cuticle, cell outlines irregular among stomata and elongated over veins. Stomata scattered and longitudinally oriented in strips more than nine stomata wide between veins. Occasionally, some stomata are very close to each other (with shared or neighbouring polar subsidiary cells). Guard cells large, well cutinized, subsidiary cells differentiated into polar and lateral. Polar cells rectangular, small. Lateral cells two in most cases, also three or rarely four (Fig. 9D, E).

\section{REMARK}

The material agrees well with the species Pseudotorellia samylinae (Kiritchkova \& Nosova 2012), who stated that it is somewhat similar to $P$. grojecensis, but that having both species in the same locality makes it easy to distinguish them on the basis of immediately observable differences in number of veins, width of stomatal strips, cell pattern, and stomata size and shape (larger and more elongated in P. grojecensis).

Pseudotorellia sp.

(Figs 9F, G; 10A)

MATERial. - One leaf fragment (middle part), and two cuticle fragments prepared from the rock.

HAND SPECIMEN. — KRAM P 141/15/II/A, 141/20/S/2, 141/02/S/8.

\section{DESCRIPTION}

Leaf linear at least in middle part, $1.7 \mathrm{~mm}$ wide. Veins not marked on lower or upper cuticle. Very fine striations (c. 12) indicating stomatal and non-stomatal bands along the blade. Leaf hypostomatic, upper and lower cuticles of equal thickness. On upper cuticle, cells with rectangular outlines, forming rows, transverse walls thicker than longitudinal ones. On lower cuticle, cell outlines narrower and more elongated, particularly over veins. Stomata occurring between veins in strips of same width as veins. Stomata oriented longitudinally, not crowded but occasionally forming groups. Polar and lateral subsidiary cells differ: polar cells rectangular, with shorter side directed to stomatal pore; lateral cells 2-4, elongated to rectangular. Each subsidiary cell possessing a hollow papilla overhanging the stomatal pore; their alternate arrangement may close it completely (Figs 9F, G; 10A). Relatively thick fibres adjoin cuticles.

\section{REMARKS}

The very narrow leaf and cuticular structure are exceptional (very elongated cells and peculiar stomata strongly regulated by papillae). Unfortunately, a more precise determination cannot be made from the small macroremain.

\section{Order CONIFERALES incertae sedis Genus Bilsdalea Harris, 1952}

\section{Bilsdalea dura Harris}

(Fig. 10B-F)

Annals and Magazine of Natural History, London 12 (5): 374, text figs 6A-F, 7A-Z, 8A-E, 9A, D, F (Harris 1952); Acta Hortibergiani 17 (10): 315, pl. 31, figs 1-9; pl. 32 figs 1-4; pl. 33, figs 1-6 (Florin 1958); Acta Palaeobotanica 25: 14, pls 1-3, text figs 1, 2 (with synonymy) (Wcisło-Luraniec 1985). - Type: Great Britain, Yorkshire, Middle Jurassic, lectotype V. 29310, Beitish Museum (Natural History), selected by Florin (1958).

Material. - Four pieces of cuticles taken from three different specimens (only very small leaf fragments preserved); also, one small leaf fragment, probably from near apex (prepared). 

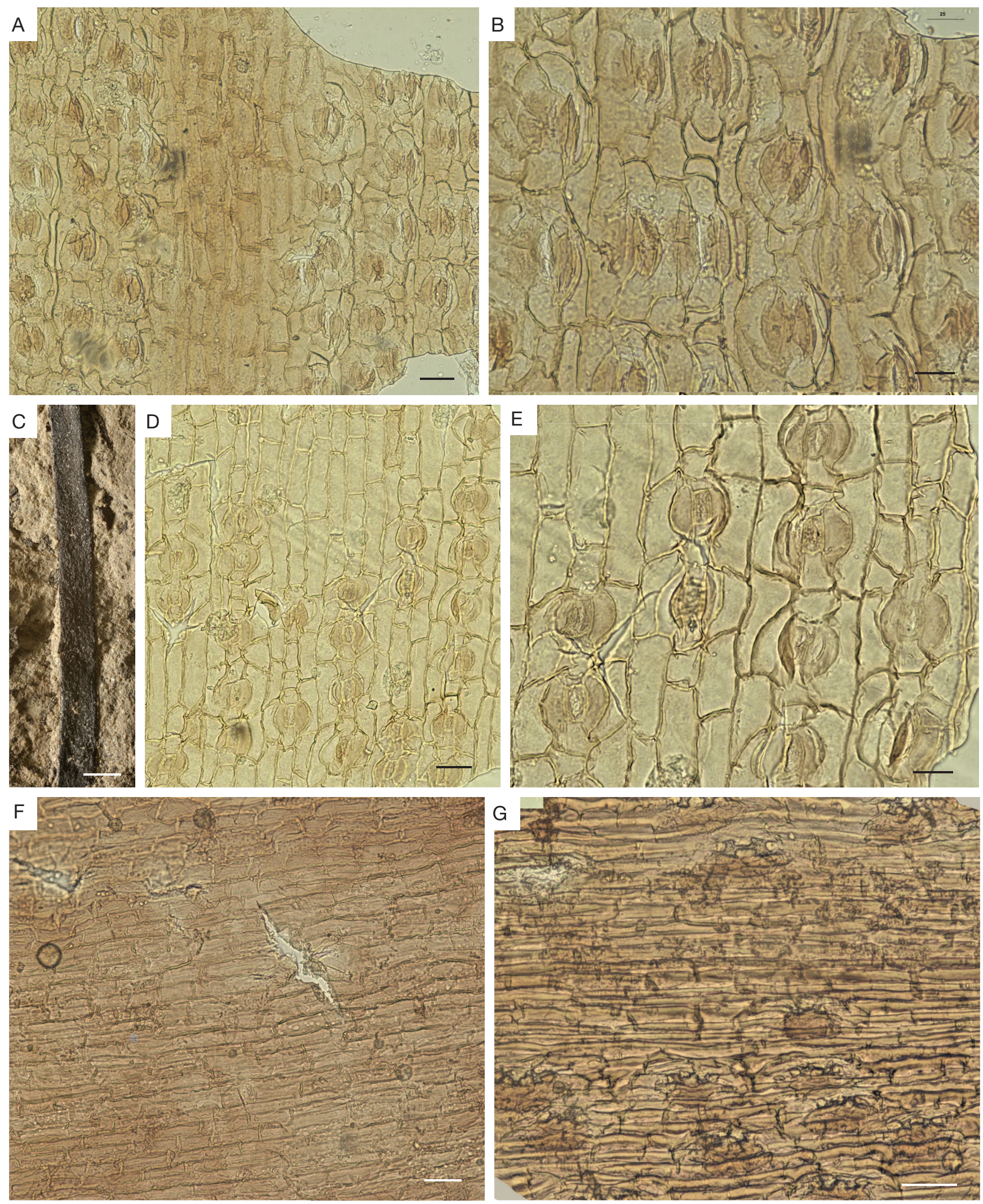

FIG. 9. - A, Pseudotorellia grojecensis Reymanówna lower cuticle (slide no. 141/09///29); B, Pseudotorellia grojecensis lower cuticle with detail of stomata (slide no. 141/09///29); C, Pseudotorellia samylinae Nosova \& Kiritchkova (no. 141-10-I); D, Pseudotorellia samylinae lower cuticle (slide no. 141/20/S/4); E, Pseudotorellia samylinae lower cuticle with details of stomata (slide no. 141/20/S/4); F. Pseudotorellia sp. upper cuticle (slide no. 141/02/S/8); G, Pseudotorellia sp. lower

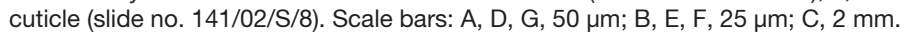



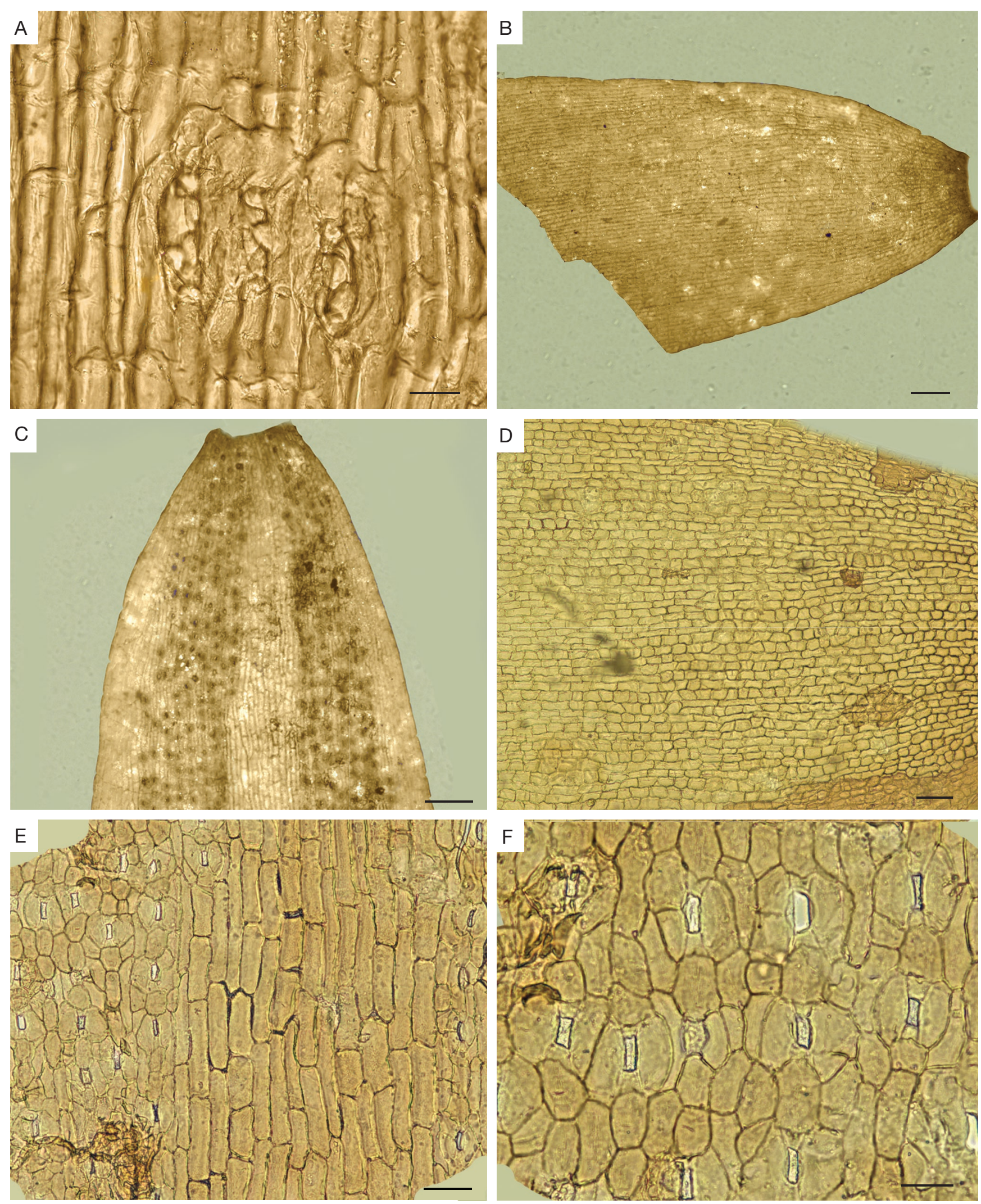

FIG. 10. - A, Pseudotorellia sp. lower cuticle, details of stomata (slide no. 141/02/S/8); B, Bilsdalea dura Harris, upper surface (slide no. 141/04/I/14); C, Bilsdalea dura lower surface (slide no. 141/04/II/14); D, Bilsdalea dura upper cuticle structure (slide no. 141/04/Il/14); E, Bilsdalea dura lower cuticle structure (slide no. 141/04/II/14); F, Bilsdalea dura lower cuticle with details of stomata (slide no. 141/04/II/14). Scale bars: A, F, $25 \mu \mathrm{m} ; \mathrm{B}, \mathrm{C}, 150 \mu \mathrm{m}$; D, $100 \mu \mathrm{m}$; E, 50 um. 

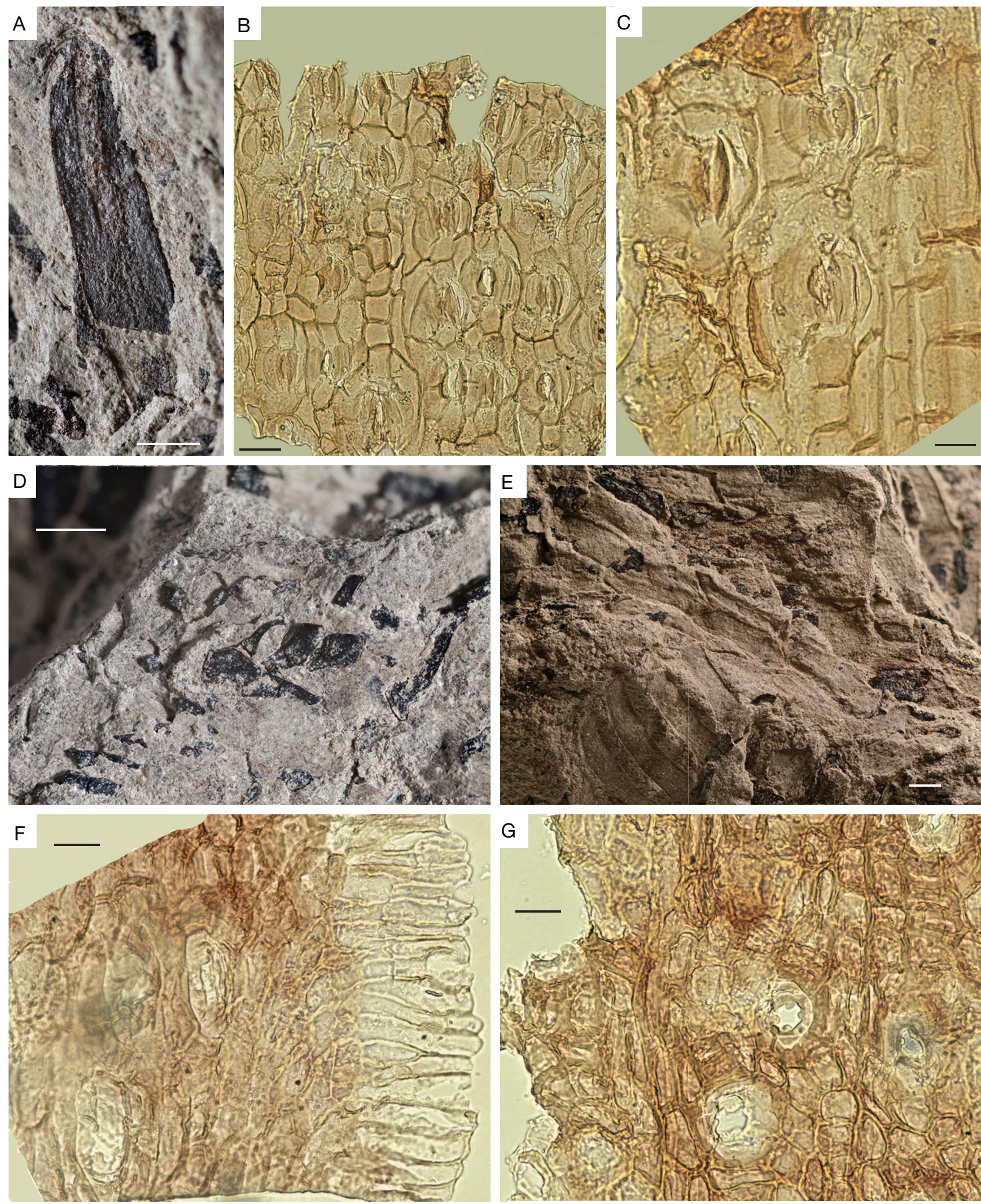

FIG. 11. - A, Mirovia szaferi Reymanówna (no. 141-10-BF); B, Mirovia szaferi lower cuticle (slide no. 141/09/I/S/5); C, Mirovia szaferi upper cuticle with details of stomata (slide no. 141/09/I/S/5); D, Brachyphyllum stemonium Kendall, terminal shoot fragment (no. 141-10-1); E, Brachyphyllum stemonium, subterminal shoot fragment (no. 141-10-2); F, Brachyphyllum stemonium lower cuticle with fringels (slide no. 141/09/I/S/9); G, Brachyphyllum stemonium lower cuticle with details of stomata (slide no. 141/09/l/S/9). Scale bars: A, D, E, 2 mm; B, $50 \mu \mathrm{m} ; \mathrm{C}, \mathrm{F}, \mathrm{G}, 25 \mu \mathrm{m}$. 
HAND SPECIMENS. - KRAM P 141/4/II/AZ, 141/04/II/S/22, 141/04/II/S/14, 141/09/I/S/13.

Age RAnge. - Middle Jurassic.

OCCURRENCE. — United Kingdom (Yorkshire), Poland (Orlej near Grojec, Kraków region, Cianowice, this paper).

\section{DESCRIPTION}

Leaf linear, $1.5 \mathrm{~mm}$ wide (estimated from shape of fragment). Apex narrowing probably to subacute or narrow obtuse. Midrib poorly visible (Fig. 10B, C). Leaf hypostomatic. On upper cuticle, cell outlines mostly rectangular, sometimes square, trapezoid or triangular, forming rows along the lamina (Fig. 10D). Cell walls straight. Cell patterns on lower cuticle similar to that on the upper cuticle, but more rectangular in stomatal bands. Stomata arranged in two wide bands on both sides of wellmarked midrib. Stomata longitudinally oriented, arranged in four rows (near apex) to nine rows (towards middle of leaf) in each band. Margins of lamina free of stomata. Sunken guard cells surrounded by four subsidiary cells, polar subsidiary cells smaller and nearly square, lateral ones as long as guard cells and extended in their middle part, such that stomatal pit narrows in the middle, and widens at ends (Fig. 10E, F).

\section{REMARKS}

Although we have only small pieces of cuticle and many macromorphological features are lacking, the midrib, two stomatal bands and peculiar stomata seen in our material are characteristic of Bilsdalea dura. All preserved details correspond well with Harris's diagnosis and description (Harris 1952, 1977), as well as with specimens described by Reymanówna (1977) and Wcisło-Luraniec (1985).

Family Miroviaceae Bose \& Manum, 1990 Genus Mirovia Reymanówna, 1985 emend. Nosova \& Wcisło-Luraniec, 2007

\section{Mirovia szaferi Reymanówna emend. Nosova \& Wcisło-Luraniec}

(Fig. 11A-C)

Acta Palaeobotanica 47 (2): 361-363, table 1, pls 1-4 (emended diagnosis and reinterpretation of type material, with synonymy) (Nosova \& W cisło-Luraniec 2007). - Mirovia szaferi Reymanówna, Acta Palaeobotanica 25 (1-2): 6-7, fig. 1, pls 1-3 (Reymanówna 1985). - Type: Poland, Grojec clays, Middle Jurassic, Mirów and Zabierzów near Krakow, Palaeobotanical collection KRAM P PM 91 and KRAM P PM 91137 in the National Biodiversity Collection - Herbarium KRAM at W. Szafer Institute of Botany, Polish Academy of Sciences, Palaeobotanical Collection KRAM P holotype: KRAM P PM 91, slide no. 887.

MATERIAL. - Three leaf fragments with apex, one fragment of cuticle, found on separate rocks. Hand specimens: KRAM P 141/9/I/26, 141/10/BF, 141/10/S/15.

AGE RANGE. — Middle Jurassic.

OCCURRENCE. — Poland (Mirów and Zabierzów, Cianowice, this paper).

\section{DESCRIPTION}

Leaf linear with obtuse apex. Veins not visible. Along adaxial side stomatal band (not sunken) visible, occupying c. 1/3 the width of lamina (Fig. 11A). Leaf hypostomatic. On upper cuticle, cell outlines rectangular to polygonal outside stomatal band, irregularly polygonal within stomatal band. Most stomata oriented longitudinally, occasionally transversally, forming $c .8$ crowded rows. Guard cells well cutinized, subsidiary cells usually four, occasionally five. Polar cells wide, lateral cells semicircular (Fig. 11B, C).

\section{REMARK}

Based on the original material, Nosova \& Wcisło-Luraniec (2007) revised and broadly discussed this species; we follow their interpretation of the genus and not the one earlier given by Bose $\&$ Manum (1990). The specimens from Cianowice show the same gross morphology and cuticular structure as the original material described by Reymanówna (1985) from Mirów and Zabierzów.

\author{
Family incertae sedis \\ Genus Brachyphyllum Brongniart, 1828b
}

\section{Brachyphyllum stemonium Kendall} (Fig. 11D-G)

Annals and Magazine of Natural History, London 11 (14): 244, text figs 7A-D, 8A-C (Kendall 1947). - Type: Great Britain, Oxfordshire, Stonesfield, Middle Jurassic, holotype no 32354, British Museum (Natural History) (Kendall 1947)

MATERIAL. - Seven conifer remains: unbranched terminal leafy shoot fragments, subterminal shoot fragments, isolated leaves, preserved as compressions or impressions.

HAND SPECIMENS. — KRAM P 141/4/II/AH2, 141/9/27, 141/10/13, 141/16/AH, 141/19/S/2.

Age Range. — Middle Jurassic.

OCCURRENCE. - United Kingdom (Wildtshire), Poland (this paper).

\section{DESCRIPTION}

Terminal leafy shoot 3-3.8 mm wide, main shoot with elongated leaves, $2.8 \mathrm{~mm}$ wide. Leaves spirally arranged, elongated, 2.2-4.3 mm long, 1.1-2.4 mm wide. Leaves on main shoot up to $6.4 \mathrm{~mm}$ long, up to $2.4 \mathrm{~mm}$ wide. Free part half or less than half of total length of the lamina. Leaf apex narrowly obtuse on terminal branches, almost acute on main shoot (Fig. 11D, E). Leaf amphistomatic, cells of both upper and lower cuticles nearly rectangular, with straight cell walls, tending to form rows. Stomata large, in single rows separated by 2-3-cell-wide non-stomatal bands. Stomatal pit surrounded by 5-6 subsidiary cells; complete ring of encircling cells common. Each subsidiary cell bearing a papilla directed inwards and overhanging stomatal pit (Fig. 11F, G).

\section{REMARK}

Kendall's (1947) emended generic diagnosis qualified shoots with leaves of equal length and width as typical Brachyphyllum 
(Brogniart 1828b), but Harris (1979) allowed this generic attribution also for forms with elongated leaves, which is the case of B. stemonium (see also diagnosis in Kendall 1947). The material from Cianowice is somewhat smaller than the original material from Wildtshire, but Kendall described her species based on a single specimen, so the range of size variability is unknown. The Polish material corresponds well with Kendall's descriptions in all aspects, both in gross morphology and in cuticular structure.

\section{GENERAL REMARKS AND PALAEOENVIRONMENTAL CONCLUSIONS}

The studied plant remains originated from 27 levels of a depositional succession (14 levels for macroflora, 13 for microflora) in an $18.9 \mathrm{~m}$ long section of the core. Pieńkowski (2014) distinguishes five major depositional successions representing different sedimentary environments: 1) depth 262.3-265.2 m: alluvial fans; 2) depth 255.3-262.3 m: fluvial plain including channel-fluvial plain-channel transitions; 3) depth 249.7255.3 m: lacustrine swamp; 4) depth 245.3-249.7 m: fluvial plain with alternation of channel-fluvial plain-channel-fluvial plain; and 5) 244.2-245.3 m, channel. Within this section, specimens with macroflora as well as palynological samples were collected from different succession levels (Appendix 1).

The macroflora from Cianowice is represented by 20 species from six groups: ferns, seed ferns, cycads, bennettitaleans, conifers and gymnosperms incertae sedis (Pseudotorellia). It is dominated by bennettitaleans, which are the most diverse and most frequent (10 species, 49 plant fragments). Conifers (3 species, 14 fragments) and Pseudotorellia (3 species, 19 fragments) are less diverse but are frequent. Among the seed ferns (2 species) only Pachypteris rhomboidalis is common (10 fragments), whereas Ptilozamites cycadea (1 fragment) and undefined cycads (1 fragment) are rare. The least frequent are ferns (1 species, 2 fragments; Fig. 12). Generally, the macroflora shows an assemblage of species having small leaves or pinnae. Here, leaves of these taxa, which in other localities reached larger size, are significantly smaller (Pterophyllum cf. aequale, Ptilophyllum sirkennethii) or fit within the minimum size range (Pterophyllum thomasii, Ptilozamites cycadea). The assemblage consists mainly of uncommon taxa otherwise known from just a single or a few localities. Moreover, the age range is in the most cases restricted to the Middle Jurassic.

Five of the 20 species are represented only by one leaf fragment (Ptilozamites cycadea, Ctenis sp., Nilssoniopteris solitaria, Ptilophyllum pecten and P. sirkennethii). The most numerous fragments belong to Pseudotorellia grojecensis (12), Pterophyllum cf. aequale (11), Ptilophyllum cf. okribense (10), Pachypteris rhomboidalis (10) and Pterophyllum thomasii (6) (Fig. 13). This suggests that the biodiversity of the assemblage was relatively high when viewed against the background of the low frequency of remains, though we note that this assertion of a relatively rich flora is based on scant material (a small-diameter core from one borehole).
The character of the remains, their fragmentation, the presence of debris, the number of remains in one core fragment - all these features suggest that the plant fragments were transported, and washed into a common sedimentary basin where they fossilized. The shared features of the examined plants, but especially the ferns, bennettitaleans and conifers, are their extremely small size and their cuticle structure. The small size of most leaves suggests that the plants grew in similar poor conditions, possibly nutrient-poor or thin soil. Except for Brachyphyllum stemonium, which is amphistomatic, all species have hypostomatic leaves. Six out of ten bennettitalean leaf species have stomata with an aperture more or less protected by papillae, and two are strongly papillate on the whole surface. Brachyphyllum stemonium also has papillae on the subsidiary cells. Ptilozamites cycadea possesses a thickened ring around the stomatal aperture, strongly restricting its size. These features may indicate periodic, climatic or topographydependent fluctuations of moisture, groundwater level, insolation, or other factors that demand control of evaporation or respiration. Soil factors like salinity or negative osmotic potential, which cause similar symptoms (Krings et al. 2005, Pott et al. 2008; Pott \& McLoughlin 2009; Haworth \& McElvain 2008, 2009), are less probable in an area having such depositional successions.

A lot of bennettitaleans are known in association with arid conditions (Diéguez et al. 2009), although a study of numerous species of Otozamites from China suggests that some Late Triassic-Early Jurassic species were connected with warm and humid tropical - to subtropical climate (Wang et al. 2008). Bomfleur et al. (2011) also discussed adaptation of Otozamites to different conditions. In Cianowice, Otozamites species as well as other bennettitaleans were adapted to dry conditions, similarly to other taxa from this area. The most frequent genera apart from the bennettitaleans, such as Pachypteris, Mirovia and some species of Brachyphyllum are usually connected with rather arid conditions (respectively: Vakhrameev 1991; Gomez 2002; Thévenard et al. 2005), whereas Pseudotorellia and some other species of Brachyphyllum may prefer wet conditions (respectively Nosova \& Golovneva 2018; Barbacka 2011). In our opinion, a very common feature of the specimens from Cianowice, such as equal cuticle thickness on both sides of the lamina may suggest that solar radiation was not very intense and might depend on the exposure. All xeromorphic features observed in the plants from Cianowice are specific for those taxa. Their xeromorphism reduced the size of the leaves as compared with plants from the same taxa but from other localities.

The dry conditions were not favourable for plant groups such as lycopsids, ferns or ginkgophytes, which prefer moist habitats. The absence of these plant groups may also be explained by taphonomic or other biasing factors such as the limitation of sampling to the core, which, if bored exactly through the depositional basin with plant fragments from the slope, could not contain plant remains from the surroundings.

Early Jurassic floras very abundant in bennettitaleans are known from coastal-lagoon deposits of Vendée, France (De Zigno 1856-1868, 1873-1885; Grandori 1913a, b; 


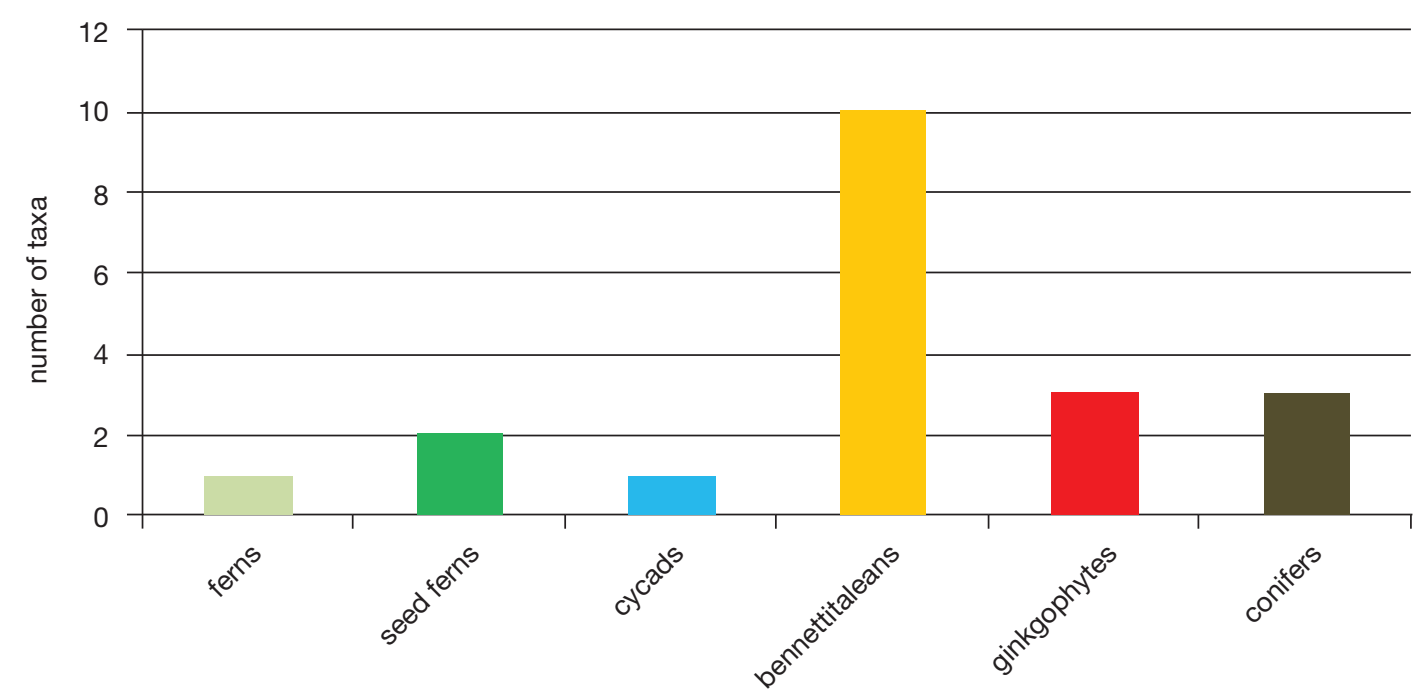

FIG. 12. - Taxonomic composition of macroflora from Cianowice 2, with number of species in particular plant groups.

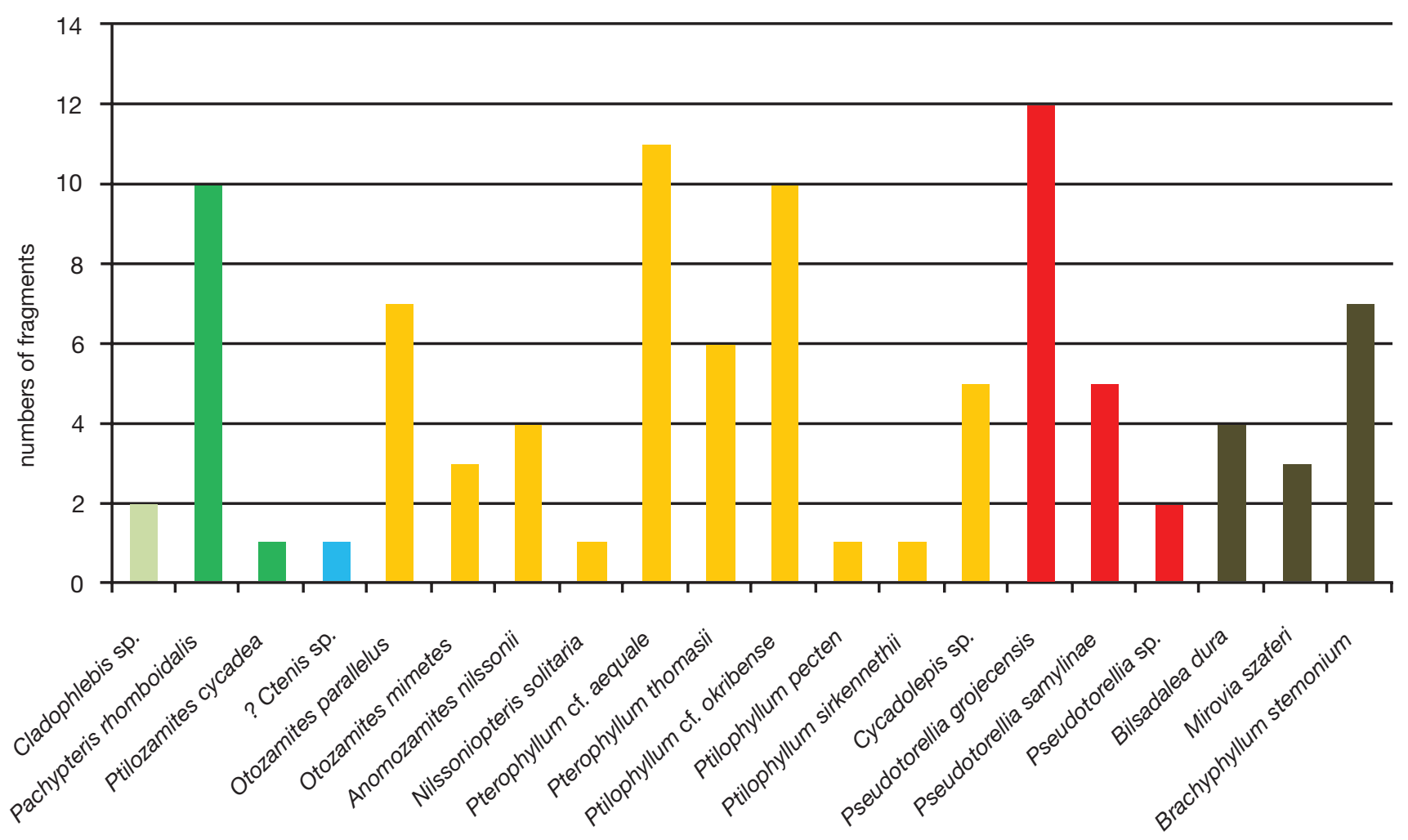

FIG. 13. - Cianowice 2, frequency of leaf fragments from particular species. Colours of plant groups according to Figure 12.

Wesley 1956, 1958, 1966, 1974; Bartiromo \& Barone Lumaga 2009), allochthonous coastal-lagoonal deposits of Veneto, Italy (environment Barbacka et al. 2014a, Bartiromo \& Barone Lumaga 2009; Scanu et al. 2015), and fluvial deposits at Reşița, Romania (Krasser 1915; Semaka 1962a, b, 1965, 1970; Givulescu 1997, 1998; Popa 1997a, 1997b, 1998, 2000a, 2000b, 2009; Popa \& Van Konijnenburg-van Cittert 2006). Bennettitaleans are diverse in these floras, but during the Jurassic they were generally one of the richest and most diverse groups. The same applies to the Middle Jurassic of Yorkshire, United Kingdom , connected to a delta/fluvial depositional environment (Harris 1969; Van Konijnenburgvan Cittert \& Morgans 1999). For this study, however, more interesting are the small and relatively homogenous assemblages with significant domination of bennettitaleans and sparse other plant taxa. These include assemblages from localities in Sardinia (i.e., Krasser 1912, 1913, 1920; Scanu et al. 2012, 2015) and Mamers, France (Philippe et al. 1998), 
which were assigned to coastal environments (discussed by Barbacka et. al. 2014a). The Late Jurassic-Early Cretaceous plant assemblage of Villelo (Spain) was interpreted as a dry savannah type of community (Diéguez et al. 2009) or growing in drier areas of flood plains (Popa 2014).

In Poland, Reymanówna (1963b) described the Middle Jurassic flora from Grojec (in her paper the Early Jurasssic). Two species present in Grojec were found in Cianowice (Bilsdalea dura, Mirovia szaferi) but the two localities are not similar. The flora from Grojec, although also connected with fluvial deposits, is dominated in number and diversity by ferns (Barbacka et al. 2014a; Jarzynka 2016). In Cianowice, fern diversity was represented only by spores.

\section{FLORISTIC OCCURRENCES ALONG THE DEPOSITIONAL SUCCESSIONS}

The taxonomic composition of the plant assemblages in particular successions and subordinate depositional environments changed little. In fact, the same taxa of the micro- and macroflora occurred along the whole sequence, appearing in depositional environments within successions in different numbers and combinations (for more details see Appendix 1).

\section{SUCCESSION 1:}

- Alluvial fan (264.20-264.18 m): macroremains not found. Cheirolepidiaceae pollen grains dominate (30/slide, average count from 2 slides - this applies to all palynological data); spores of Dicksoniaceae-Cyatheaceae-Dipteridaceae-Matoniaceae type and pollen grains of Caytoniales are sporadic.

\section{SUCCESSION 2}

- Channel (262.0-262.0 m): Macroremains are very sporadic in the lower part of the deposit, with Cycadolepis sp. (1 specimen) and Brachyphyllum stemonium (1). Sporadic fern spores of Dicksoniaceae-Cyatheaceae-Dipteridaceae-Matoniaceae type (10) and single pollen grains of Caytoniales.

- Flood plain (258.8 m): sporadic fern spores of Dicksoniaceae-Cyatheaceae-Dipteridaceae-Matoniaceae type.

- Channel (255.7-256.55 m): In the lower part of this deposit occur Pachypteris rhomboidalis (3) Pterophyllum cf. aequale (1), Pterophyllum thomasii (1) and Brachyphyllum stemonium (1). Fern spores are sporadic, as are pollen grains of Erdtmanithecales and Cheirolepidiaceae. In the upper part of this deposit the macroflora is richer and more diverse yielding Cladophlebis sp. (1), Pachypteris rhomboidalis (2), Otozamites parallels (1), Pterophyllum thomasii (1), Pterophyllum cf. aequale (2), Ptilophyllum cf. okribense (8), Cycadolepis sp. (4), Ctenis sp. (1), Pseudotorellia grojecensis (1), Pseudotorellia samylinae (2), Bilsadalea dura (7), Brachyphyllum stemonium (3) and Mirovia szaferii (3). Dicksoniaceae-Cyatheaceae-DipteridaceaeMatoniaceae (80) and Marattiaceae (34) type fern spores have a higher frequency as well as pollen of Cheirolepidiaceae (78) and Erdtmanithecales (37). Other sporomorphs (Osmundaceae, Schizaeaceae, Cycadales, Bennettitales, Araucariaceae, Caytoniales) are very sporadic.

\section{SUCCESSION 3}

- Lacustrine, swamp (255.3-250.1 m): DicksoniaceaeCyatheaceae-Dipteridaceae-Matoniaceae (219) and Schizaeaceae (Klukisporites, 38) type spores dominate the lower part of the succession. All other sporomorphs (Osmundaceae, Pteridaceae, Erdtmanithecales, Araucariaceae, Cheirolepidiaceae, Caytoniales) are sporadic (less than 10 spores/pollen grains per slide). In the upper part of the deposit occur, among the macroremains, Ptilophyllum pecten (1), Pterophyllum thomasii (2), Pachypteris rhomboidalis (3), Pseudotorellia grojecensis (7), Otozamites mimetes (2), Otozamites parallelus (2), and Pseudotorellia samylinae (1), and significantly fewer sporomorphs than in the lower part of the deposit: Dicksoniaceae-Cyatheaceae-Dipteridaceae-Matoniaceae spores (17) and Araucariaceae pollen (13), and other sporomorphs (Lycophyta, Osmundaceae, Marattiaceae, Erdtmanithecales, Caytoniales, Taxodiaceae, bisaccate pollen grains of conifers or seed ferns) were sporadic or single.

\section{SUCCESSION 4}

- Channel (249.4-247.7 m): In lower part of the deposit are preserved Cladophlebis sp. (1), Pachypteris rhomboidalis (1), Ptilozamites cycadea (1), Otozamites parallelus (3), Pseudotorellia samylinae (1) and Pseudotorellia sp. (1). The sporomorph assemblage is not rich: Dicksoniaceae-Cyatheaceae-Dipteridaceae-Matoniaceae (17) and single spore/pollen grains belonging to the Lycophyta, Osmundaceae, Erdtmanithecales and Taxodiaceae. In the upper part of this deposit the sporomorph assemblage is almost the same with abundant Dicksoniaceae-Cyatheaceae-Dipteridaceae-Matoniaceae spores (11) whereas other fern spores, Erdtmanithecales and Taxodiaceae pollen grains are sporadic.

- Fluvial plain (247.3 m): Some species for the first time in this sequence, including Anomozamites nilssonii (4), Nilssoniopteris solitaria (1), Ptilophyllum sirkennethii (1) and Pseudotorellia sp. (1) apart from occuring before Pterophyllum thomasii (1), Ptilophyllum cf. okribense (2), Pseudotorellia grojecensis (1).

- Channel $(246.9 \mathrm{~m})$ : the macroplant assemblage is less diverse with Otozamites mimetes (1), Pseudotorellia samylinae (1), Pterophyllum thomasii (1) and Pseudotorellia grojecensis (2).

- Fluvial plain (246.0-245.3 m): Pachypteris rhomboidalis (1), Otozozamites parallelus (1), Pseudotorellia grojecensis (3) occur among the macroremains and single pollen grains of Erdtmanithecales and Caytoniales in the microflora.

\section{COMPOSITION OF FLORA}

In overall the macroplant assemblages is dominated by the gymnosperms, with hygrophytic plant groups such as lycophytes, horsetails and ginkgophytes lacking, and ferns and cycads are very sparse. The microflora consists of 19 taxa (Figs 14A-O; 15A-L), similar to the number of taxa in the macroflora, but the two assemblages differ in composition. The most abundant among the sporomorphs are the fern spores belonging to the Dicksoniaceae-CyatheaceaeDipteridaceae-Matoniaceae, Schizaeaceae and Marattiaceae, followed by conifer pollen grains (mainly Cheirolepidiaceae) and Erdtmanithecales. Other sporomorphs are present only 
A

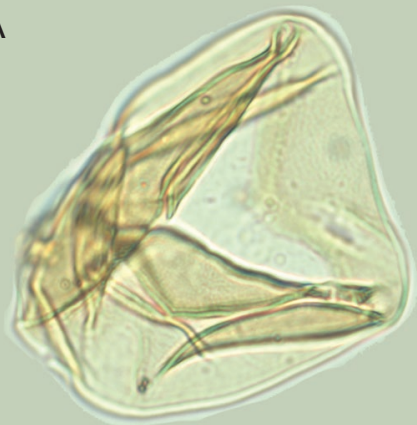

B

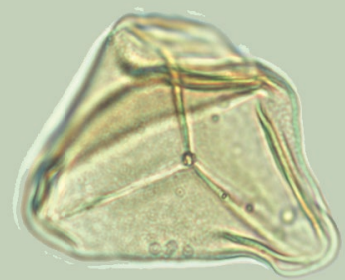

C

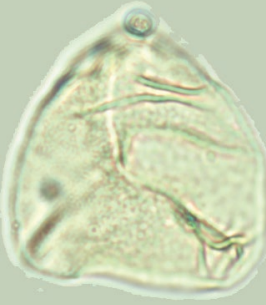

D

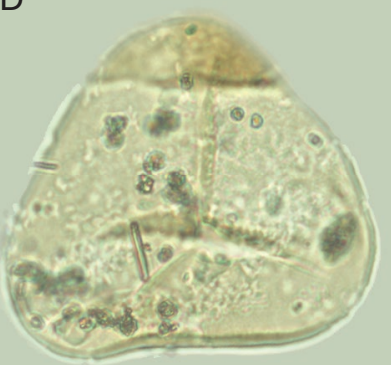

E

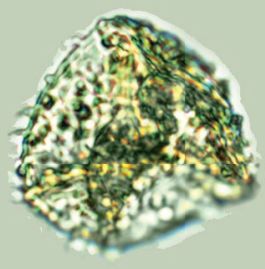

F

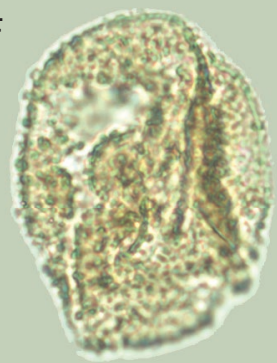

G

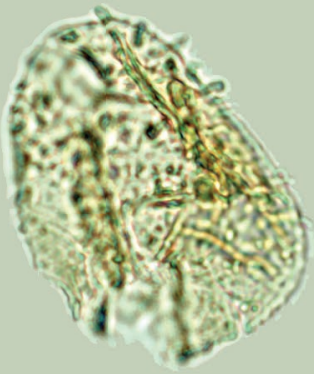

$\mathrm{H}$

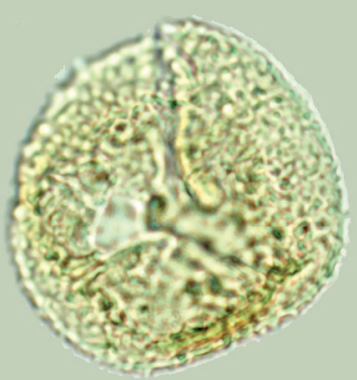

I
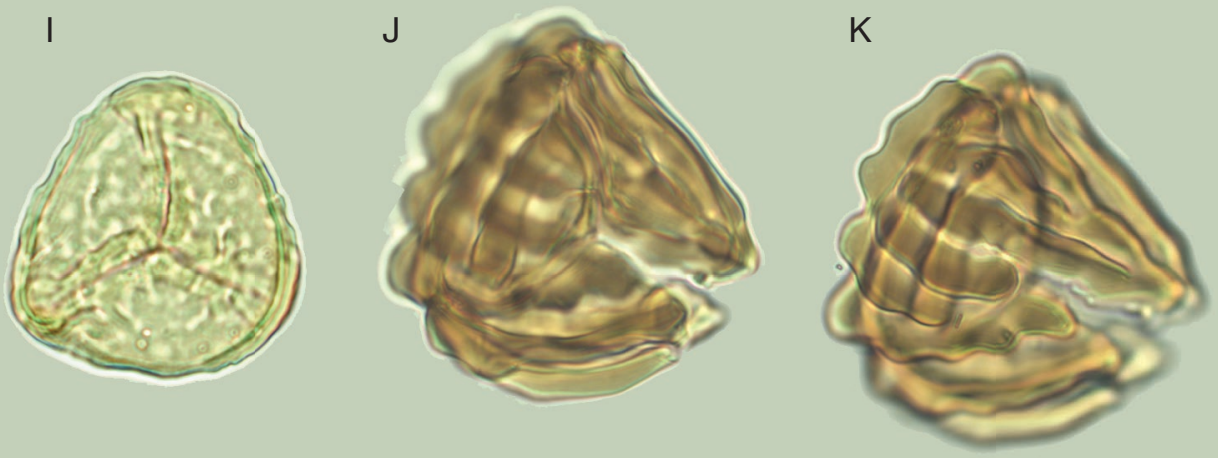

L

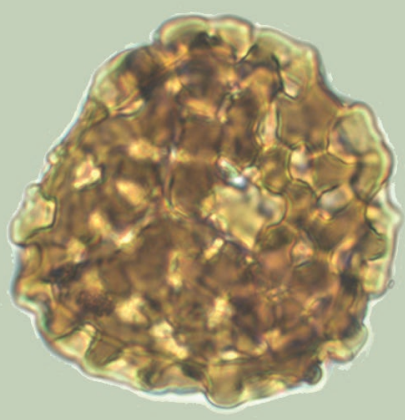

M

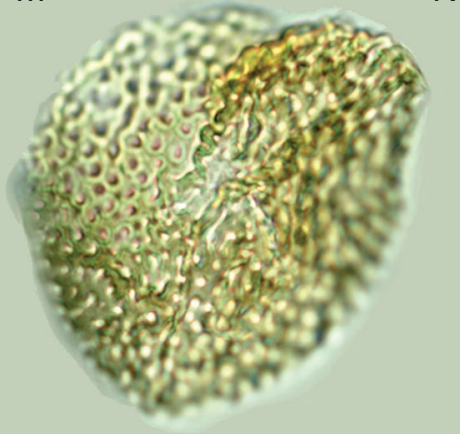

N

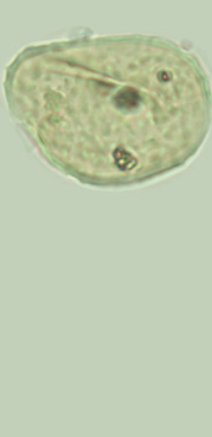

O

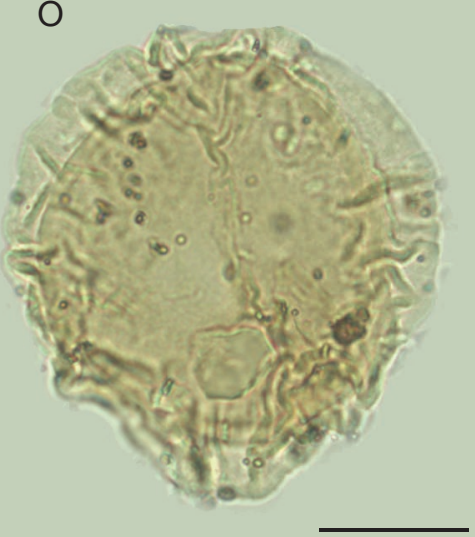

FIG. 14. - A, Cyathidites sp.; KRAM P 141 (255.3 m / 2); B, Deltoidospora sp. 1; KRAM P 141 (255.3 m / 2); C, Deltoidospora sp. 2; KRAM P 141 (255.3 m /2); D, Deltoidospora sp. 3; KRAM P 141 (255.3 m / 2); E, Apiculatisporites sp.; KRAM P 141(250.1 m / 2); F, Baculatisporites sp. 1; KRAM P $141(255.3$ m / 1); G, Baculatisporites sp. 2; KRAM P 141(249 m / 2); H, Osmundacidites wellmanii Couper; KRAM P 141 ( 249 m / 2); I, Lycopodiacidites sp.; KRAM P 141(249 m / 2); J, Contignisporites sp.; KRAM P 141(255.3 m / 2); K, Contignisporites sp.; KRAM P 141(255.3 m / 2); L, Klukisporites variegatus Couper; KRAM P 141(255.3 m / 2); M, Sestrosporites sp.; KRAM P 141(249 m / 2); N, Marattisporites scabratus Couper; KRAM P 141 (256 m / 1); O, Callialasporites dampieri (Balme) Dev; KRAM P 141 (256 m / 2). Scale bar: $20 \mu \mathrm{m}$. 
A

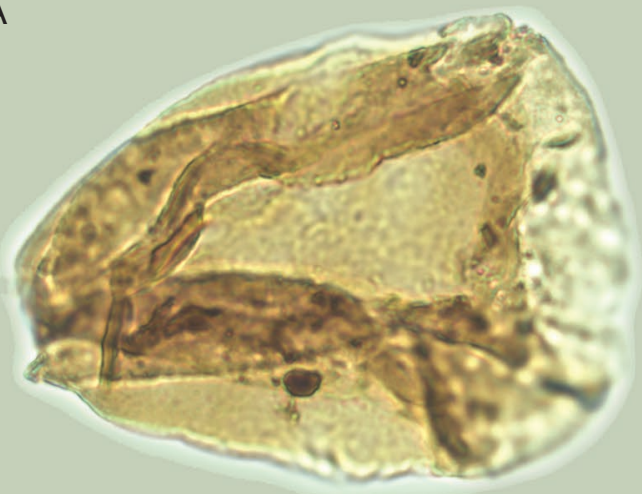

B

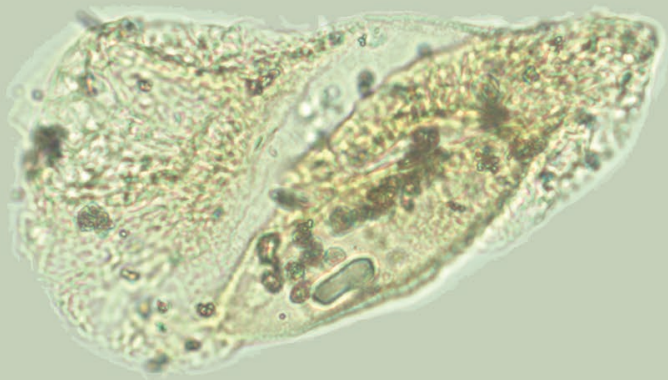

E

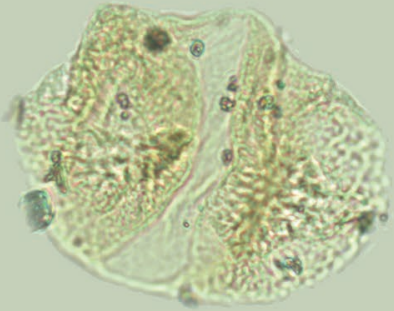

D

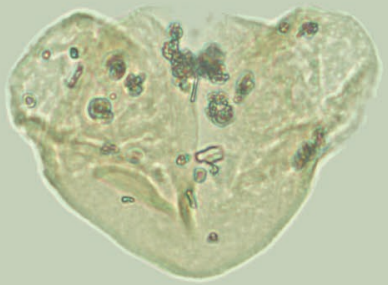

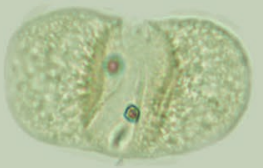

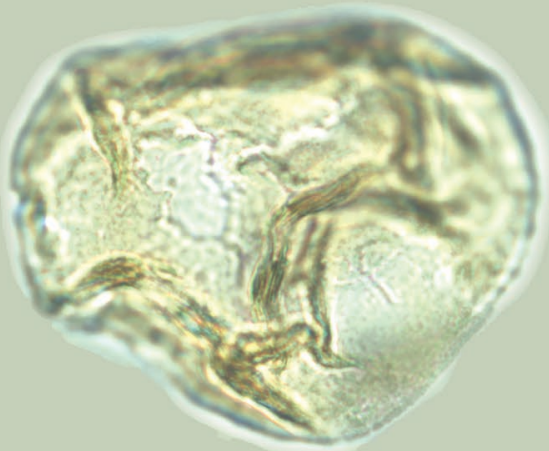

G

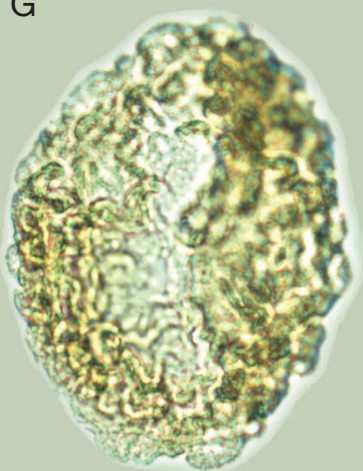

$\mathrm{H}$

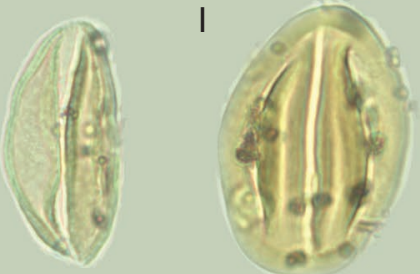

$J$

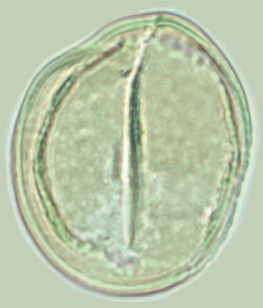

K

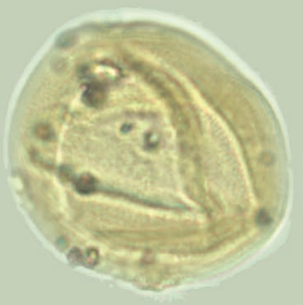

$\mathrm{L}$

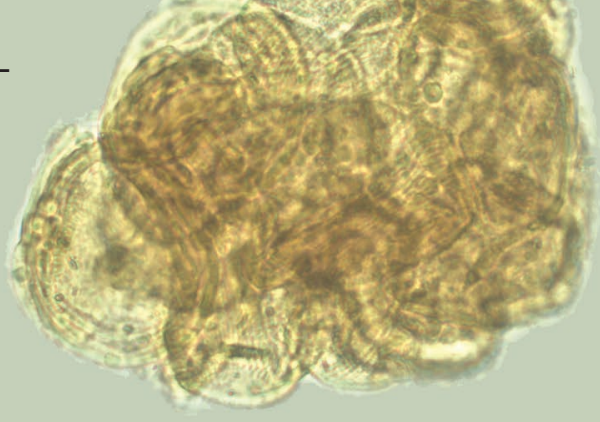

FIG. 15. - A, Callialasporites trilobatus (Balme) Dev; KRAM P 141 (255.3 m / 2); B. Bisaccate pollen grain 1; KRAM P 141 (256 m / 1); C, Bisaccate pollen grain 2; KRAM P 141 (256 m / 1); D, Bisaccate pollen grain 3; KRAM P 141 (256 m / 1); E, Vitreisporites pallidus (Reissinger) Nilsson; KRAM P 141 (256 m / 1); F, Araucariacites sp.; KRAM P 141 (250.1 m / 2); G, Cerebropollenites macroverrucosus (Thiergart) Schulz; KRAM P 141 (250.1 m / 2 ); H, ?Monosulcites sp.; KRAM P 141 (256 m/ 1); I, Eucommiidites troedssonii Erdtman; KRAM P 141 (256 m / 1); J, Eucommiidites sp.; KRAM P 141 (249 m / 1); K, Classopollis torosus (Reissinger) Couper; KRAM P 141 (256 m / 1); L, Cluster of Classopollis torosus (Reissinger) Couper pollen grains; KRAM P 141 (264.18 m / 2). Scale bar: 20 um. 


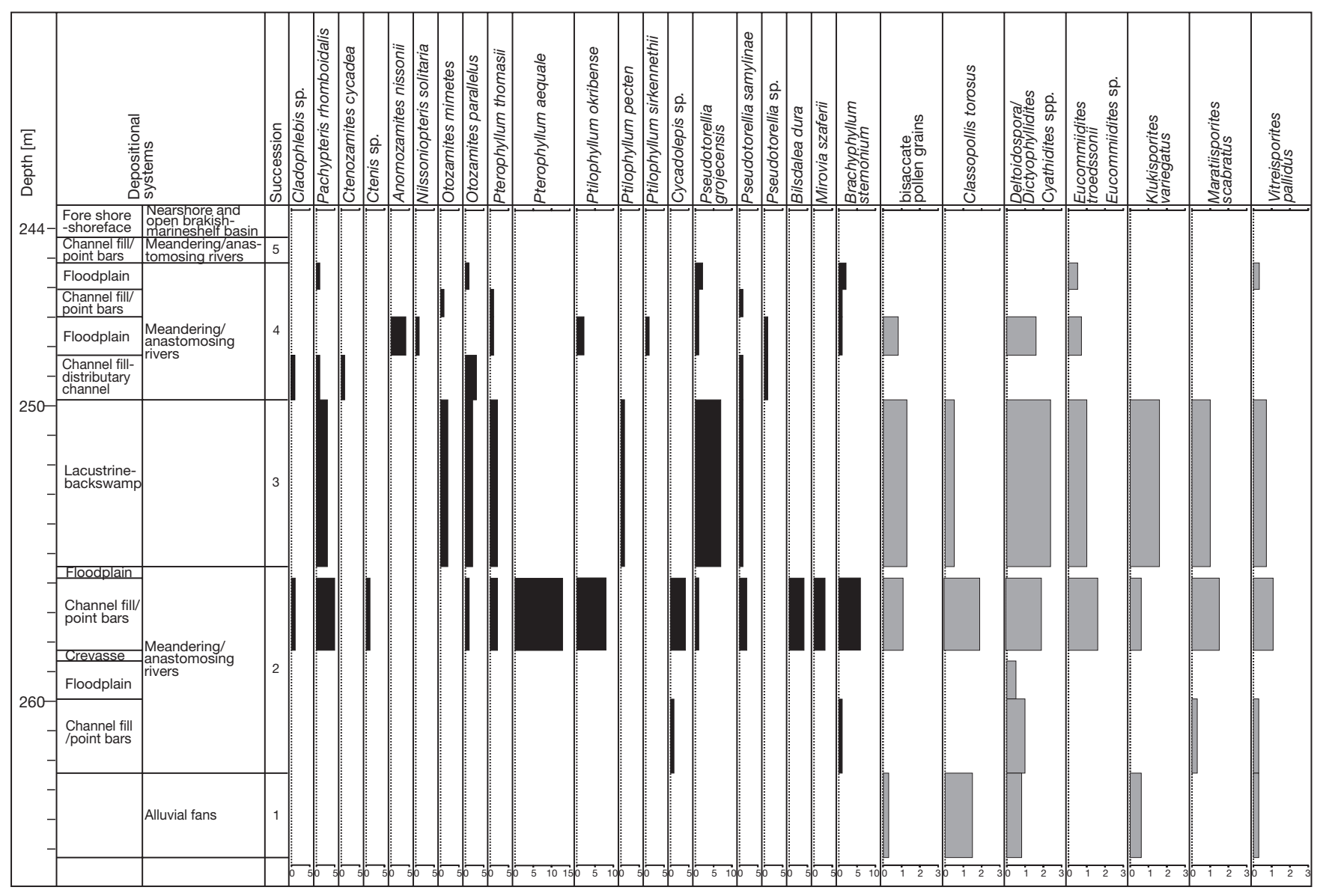

FIG. 16. - Diagram showing occurrences of macroflora (in black) and microflora (in grey) at different depths of depositional successions. Quantities of both palynomorphs and macroremains are given as sums in each depositional system. For palynological data, log values are given in order to provide a clearer overview. The value of 1 has been added to each palynomorph sum in order to take into account single occurrences.

very sporadically, however with a combination of taxa that repeats itself along the sequence. Cycadales and Bennettitales, whose leaves dominate the macroflora, are poorly represented in the microflora and are limited to the channel deposits of succession 2 (Fig. 16; Appendix 1).

Classopollis dominates at $264.18 \mathrm{~m}$ depth (alluvial fan of succession 1) with $81 \%$, but its absolute value is not high, since its average frequency (always counted from 2 slides) was 30. In the remaining levels it is represented by only few pollen grains (frequency lower than five sporomorphs). At $256.0 \mathrm{~m}$ depth (river channel deposits within succession 2) the percentage of fern spores reaches $44.6 \%$ (120 spores) in correspondence with the highest frequency for Cheirolepidiaceae (29\%, 78 pollen grains) and Erdtmanithecales (13\%, eight pollen grains). At $255.3 \mathrm{~m}$ depth (lacustrine swamp environment within succession 3), ferns reached their highest abundance $95 \%$ (222 spores on average).

The most abundant spores in the microflora belong to the ferns, and are mainly represented by the two genera Cyathidites and Deltoidospora (the poor state of preservation of the spores made it impossible to identify them at species level), which generally prefer moist conditions (Van Konijnenburgvan Cittert 2002; Wang 2002), although some of them also tolerate drier habitats (Barbacka 2011). Classopolis torosus
(Reissinger) Couper, 1958 belongs to the Cheirolepidiaceae and occurs at all levels but in lower numbers (with one exception in succession 4), This pollen type is connected with arid or coastal environments (e.g. Thévenard et al. 2005) but may also occur at moist sites (Nguyen et al. 1999).

The most common and persistent taxon among the macroremains was Pachypteris rhomboidalis, present in most depositional successions, though its record decreases through time. Other common macroplant taxa are Otozamites parallelus, Pterophyllum thomasii, Pseudotorellia grojecensis (which had its maximum abundance in the lacustrine sediments of succession 3) and P. samylinae. Brachyphyllum stemonium was not found in the lacustrine sediments but was present in all others. Generally, the abundance and number of recorded macroplant taxa as well as number of levels yielding plants decreased towards younger successions, even when the younger successions represented similar environmental types. This may suggest that conditions became less favourable for the for plant to grow and/or to preserve, or that the older successions were deposited under circumstances more favourable for the deposition of plant remains (more wind, storms, heavy rains).

The macro- and microflora from Cianowice, with its fluviolacustrine depositional environment, is represented by relatively few plant groups and there are substantial differences 


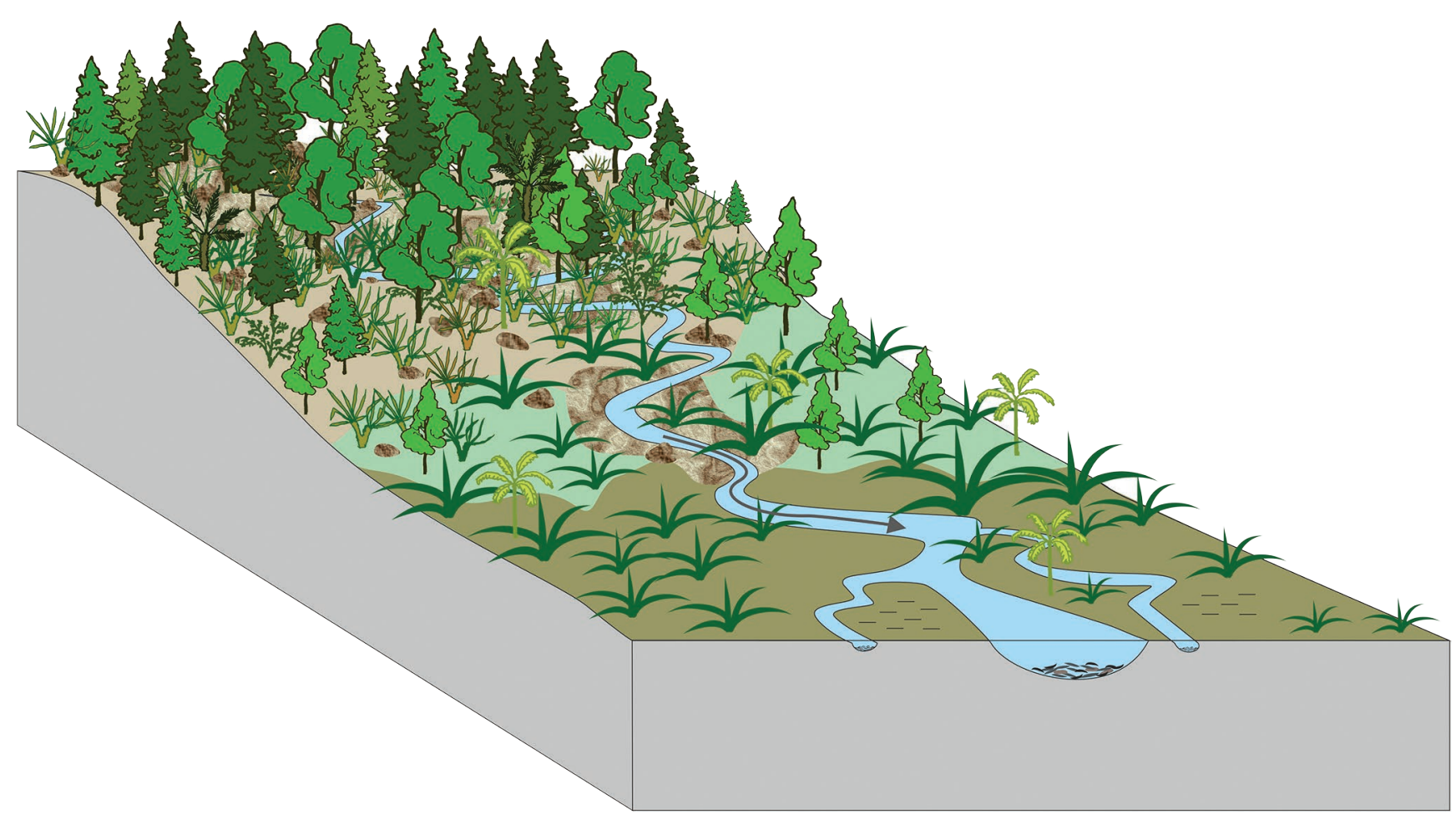

FIG. 17. - Reconstruction of hypothetical environment of Cianowice. Arrow, transport of leaves by river.

in abundance between the macro-and microfossils. The same was noted in the material from Yorkshire by Slater \& Wellman $(2015,2016)$ and explained by the dispersal of pollen and spore in different plant groups, and by the differences in their accumulation and fossilization, factors that must be considered also when interpreting the plant palaeoecology of Cianowice (see Discussion and Conclusions below).

\section{PALAEOENVIRONMENTAL RECONSTRUCTION}

\section{OF THE CIANOWICE AREA}

The proposed palaeoenvironmental reconstructions (Fig. 17) is based on the environmental adaptation of the various plants from Cianowice (macro-and microflora) and on some taphonomic considerations:

- Gross morphology and cuticular structure of the macroremains suggest rather dry conditions;

- Macroflora and microflora differ in composition along the core and between adjacent levels along the depositional succession;

- Depositional environments (fluvial-lacustrine-fluvial) reconstructed based on sedimentological analyses do not agree with the micro-and macromorphology of most remains, which show rather xeromorphic features;

- Plant remains show high fragmentation and accumulation of leaves (up to 7 species represented by 8 leaf fragments in one sample);

- Fern spores dominate the palynological samples, unlike in the macroremains.

Assuming that the sporomorph producers lived at approximately the same time (the distances between the analysed slices were short), we conclude that the gymnosperms grew in dif- ferent position from the ferns found in the plant assemblage, possibly on a rise above over a river/lake plain dominated by ferns. The small leaf size might be due to them growing on a rocky/stony slope and/or under the influence of constant wind, which could limit growth and account for the equal thickness of cuticles on both leaf surfaces of plants growing in a dry but not necessarily very sunny place. Well-drained soils on the elevation slope and the periodic influence of wet air from the plain might support regulation of stomatal pores by papillae or a thickened ring, a mechanism common in this locality. The role of wind helps to explain the poverty of bisaccate pollen grains in the samples, but their producer Pachypteris, represented also by macroremains, is very common in the majority of strata (since pollen diversity is much richer than macroremains, it is not excluded that there were also different producers of bisaccate pollen grains, e.g. certain conifers or seed fern taxa). The bisaccate pollen grains found in the Cianowice sediments may also have originated from conifers or seed ferns growing far from the site of deposition (e.g. from vegetation of higher terrain). While the leaves were washed down by rain or stream/river water to the plain and were fossilized in rapidly deposited flood sediment, the bisaccates could have been blown away from the area of deposition. This may also be a matter of differences in the type of transport for micro-and macroremains which influence the interpretation of paleoenvironment (Kustatscher et al. 2012; Costamagna et al. 2018).

The situation is different in the case of Cheirolepidiaceae and bennettitalean pollen, which lack air sacs. The structure of cheirolepidiaceous Classopollis pollen grains has no analogues in the pollen of recent floras. The small size and large 


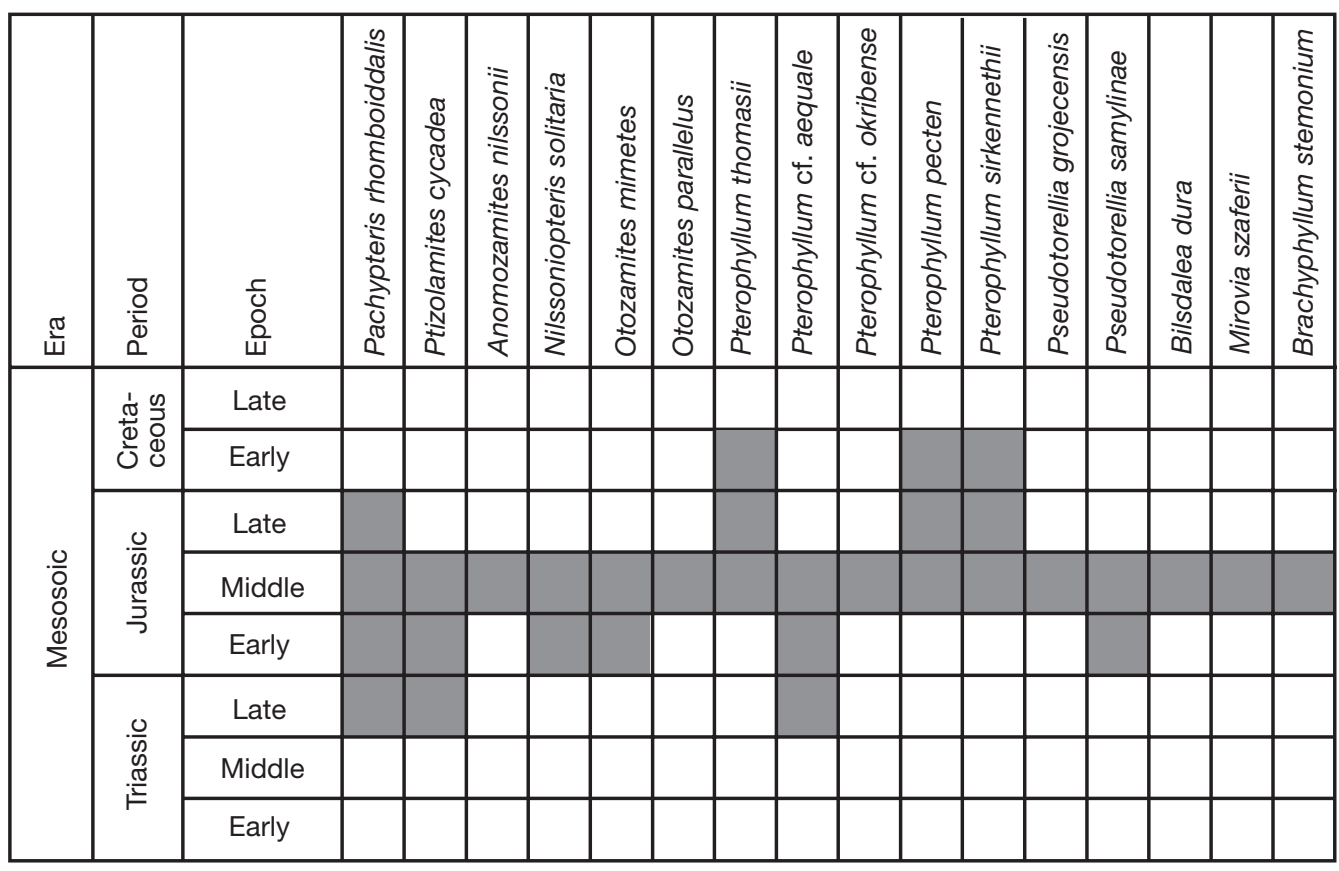

FIG. 18. - Stratigraphic extension of the macroremains (e.g. Johansson 1922; Kendall 1947; Reymanówna 1963a, 1985; Doludenko \& Svanidze 1964; Harris 1964, 1969, 1977; Achilles 1981; Szydeł \& Szydeł 1981; Van Konijnenburg-van Cittert \& van der Burgh 1989; Watson \& Sincock 1992; Cleal \& Rees 2003; Nosova \& Wcisło-Luraniec 2007; Diéguez et al. 2009; Pott \& McLoughlin 2009; Kiritchkova \& Nosova 2012; Barbacka et al. 2014a, 2017).

amount of Classopolis pollen grains produced by male cones of Hirmeriella, for example, suggest wind dispersal. Classopollis pollen grains tend to remain in tetrads or to form clusters. Not only wind but also insects may have taken part in the transport of Classopollis pollen grains (Hughes 1976; Alvin 1982). Bennettitaleans were at least partly insect-pollinated (Crane 1986; Crepet et al. 1991), and their pollen production level is relatively low (Norstog 1987). The sediments yelding plant remains contain a high percentage of spores belonging to a rich, diverse fern assemblage that probably grew along river or lake banks on the plain. This corresponds to their potential habitats and suggests that at least some fern spores were dispersed at the site where they were produced (Slater $\&$ Wellman 2016). This phenomenon is also explained as the "Neves effect" (Chaloner \& Muir 1968) according to which the continental deposits, especially hill slopes can be richer in spores than in pollen grains (especially bisaccate ones) which are transported by wind beyond the area where the plants grow.

The highest amount of spores was found in the lacustrine swamp succession. The almost complete absence of fern macroremains in the core raises the possibility that, perhaps, their leaves were more vulnerable to damage by destructive factors such as water currents. The sporadic occurrence of pollen grains produced by the bennettitaleans dominating the macroflora can be explained by their relatively low dispersal ability by wind (Slater \&Wellman 2015, 2016).

\section{POSSIBLE AGE OF THE FLORA}

Most of the European floras that contain many and similarly diverse bennettitaleans are known from the Middle Jurassic:
Sardinia (25\% bennettittalean species), Yorkshire (24\%), and Mamers, France (56.6\%) (Barbacka et al. 2014a). Cianowice also has a high percentage (45\%). Moreover eight of the total number 20 species have been reported exclusively from the Middle Jurassic (Figs 18; 19). Three species are known from the Early-Middle Jurassic, two range from the Middle Jurassic to Early Cretaceous, and one ranges from the Late Triassic to Early Cretaceous. One species, Pterophyllum cf. aequale, is known from the Late Triassic-Early Jurassic; possibly its occurrence in Cianowice would extend its age range from the Late Triassic to the Middle Jurassic.

The Cianowice material contains four taxa common to the Middle Jurassic flora of Poland. Two species, Pseudotorellia grojecensis (Reymanówna 1963b) and Mirovia szaferi (Reymanówna 1985), were established by Reymanówna from Grojec and Mirów respectively. One species, Bilsdalea dura, was reported by Reymanówna (1977) from Orlej. To our knowledge, these three species are so far restricted to the Middle Jurassic floras of Poland. All of the localities are situated in one region near Cracow. In Poland the fourth species, Pachypteris rhomboidalis, is noted from the Early or Middle? Jurassic of Lublin area. Its palaeogeographic and age range is wider from Early to Late Jurassic.

The sporomorph assemblages from Cianowice suggest an age not older than an Early Jurassic (Toarcian). Cerebropollenites macroverrucosus (Thiergart) Schulz, 1967 is reported from the Sinemurian but is not common; it may be abundant at some younger intervals such as the Toarcian-Aalenian. Klukisporites variegatus Couper, 1958 (also known as Ischyosporites variegatus (Couper) Schulz, 1967) is reported from the latest Pliensbachian. Callialasporites dampieri (Balme) Dev, 1961 and Callialasporites trilobatus (Balme) Dev, 1961 first appear in 
upper Toarcian beds and are common in the Middle Jurassic from the Aalenian to Bathonian (Callialasporites-Perinopollenites Zone). The approximate time for the first appearance for Marattisporites scabratus Couper, 1958 is Rhaetian but these spores occur mainly in Aalenian - ?Bathonian strata. Baculatisporites comaumensis (Cookson) Potonié, 1956, Osmundacidites wellmanii Couper, 1953, Eumommiidites troedssonii Erdtman, 1948 and Vitreisporites pallidus (Reissinger) Nilsson, 1958 are not diagnostic (according to e.g. Batten \& Koppelhus 1996) and/ or found in wide temporal spans of the Late Triassic and/or Jurassic of Northwestern Europe. Trilete, smooth fern spores from the genera Cyathidites, Concavisporites and Deltoidospora are also reported from almost all Jurassic sediments.

Similar taxa (without Callialasporites and Baculatisporites) were found in the Grojec clays (Ichas 1986). Sporomorphs from the Grojec clays dated to the Middle Jurassic by Marcinkiewicz (1980) on the basis of megaspores are not specific for this age.

To summarize, the sporomorphs may restrict the succession of Cianowice to the upper Lower Jurassic (Toarcian) or to the Middle Jurassic, whereas the majority of leaf fossils represent taxa hitherto reported mainly from the Middle Jurassic. This tends to support the interpretation that the siliciclastic deposits from Cianowice (at least the for its major part) would be of Middle Jurasssic age.

\section{CONCLUSIONS}

The flora from Cianowice is rather poorly differentiated, with a lack of horsetails, lycophytes or ginkgophytes, and very sparse occurrence of ferns in the macroremains. It is also strongly biased taphonomically. Despite this, it yielded interesting new data for Middle Jurassic floras of Europe and Poland, as an example of a locally affected assemblage. It is one of the few bennettitalean-dominated floras from the Middle Jurassic of Europe, and contains taxa known from Europe and Poland but from areas situated far from Cianowice.

The plants of the whole assemblage show gross morphology and cuticle structure (small size of leaves/leaflets, thick cuticle, frequent papillae, protected stomata) influenced by harsh environmental conditions. This relatively monotypic plant assemblage apparently was formed by local conditions different from those suggested by the depositional succession of the borehole site. The record suggests that the plant composition was the same (although in different species combinations) during the whole time interval represented by the sequence. It also seems that the changing depositional environment in the basin had no significant impact on the original flora of the vicinity that was washed in this basin.

\section{Acknowledgements}

We are grateful to Katarzyna Cywa, Barbara Kurdziel and Barbara Nowaczyńska for laboratory work, Agnieszka Sojka for drawing the reconstruction, Marian Szewczyk for photos, and Grzegorz Pieńkowski for critical suggestions during

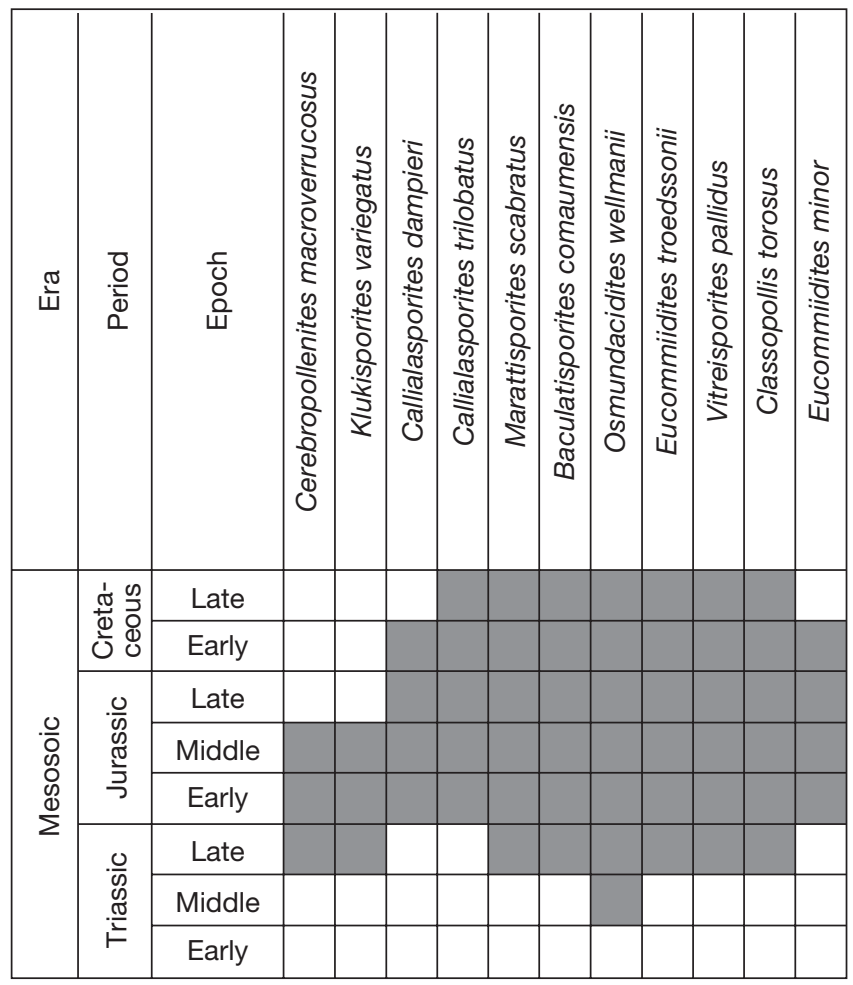

FIG. 19. - Stratigraphic extension of the microremains (e.g. Couper 1953, 1964 Orłowska-Zwolińska 1966, 1983; Schulz \& Mai 1966; Lammons 1969; Pocock 1970; Herngreen 1971; Morbey 1975; Lakhanpal et al. 1976; Lund 1977; Pedersen \& Lund 1980; Achilles 1981; Van der Eem 1983; Hoelstad 1985; Weiss 1989; Askin 1990; Baldoni 1992; Batten \& Koppelhus 1996; Vajda 2001; Kustatscher et al. 2006, 2010a, b; Kürschner et al. 2007; Sajjadi et al. 2007; Bonis et al. 2009; Dehbozorgi et al. 2013; Krupnik et al. 2014; Mays 2015; Barbacka et al. 2017; Badihagh et al. 2019).

the writing of this paper. We thank the reviewers Benjamin Bomfleur and Mihai Emilian Popa for their help through many valuable suggestions, and Evelyn Kustatscher for guidance during processing of the manuscript. Funding: the study was financed by funds from the National Science Centre, Poland (no. 2017/25/B/ST10/01273), and by the W. Szafer Institute of Botany, Polish Academy of Sciences, though its statutory funds.

\section{REFERENCES}

ACHILles H. 1981. - Die rätische und liassische Mikroflora Frankens. Palaeontographica Abt. B 179: 1-86.

Alvin K. L. 1982. - Cheirolepidiaceae: Biology, structure and palaeoecology. Review of Palaeobotany and Palynology 37: 71-98. Anderson H. M., Barbacka M., Bamford M. K., Holmes W. K. \& ANDERSON J. M. 2019. - Umkomasia (megasporophyll): part 1 of a reassessment of Gondwana Triassic plant genera and a reclassification of some previously attributed. Alcheringa 43 (1): 1-28. https://doi.org/10.1080/03115518. 2018.1480801

ANDRAE C. 1855. - Beitrage zur kenntniss der fossilen Flora Siebenburgens und des Banates. Abhandlungen der K. K. geologischen Reichsanstalt 3 (4): 1-48.

Askin R. A. 1990. - Cryptogam spores from the upper Campanian and Maastrichtian of Seymour Island, Antarctica. Micropaleontology 36 (2): 141-156. https://doi.org/10.2307/1485498 
Badihagh M. T., SajJadi F., Farmani T. \& Uhl D. 2019. Middle Jurassic palaeoenvironment and palaeobiogeography of the Tabas Block, Central Iran: palynological and palaeobotanical investigations. Palaeobiodiversity and Palaeoenvironments 99: 379-399. https://doi.org/10.1007/s12549-018-0361-0

BALdoni M. A. 1992. - Palynology of the Lower Lefipan Formation (Upper Cretaceous) of Barranca de Los Perros, Chubut Province, Argentina. Part I. Cryptogam Spores and Gymnosperm Pollen. Palynology 16: 117-136. https://doi.org/10.108 0/01916122.1992.9989410

Barbacka M. 1997. - Ctenozamites cycadea (Berger) Schenk from the Mecsek Mountains Liassic - S. Hungary, in HerNGREEN G. F. W. (ed.), Proceedings 4th European Palaeobotanical and Palynological Conference. Mededelingen Nederlands Instituut Toegepaste Geowetenschappen TNO 58: 81-85.

BARBACKA M. 2011. - Biodiversity and the reconstruction of Early Jurassic flora from the Mecsek Mountains (southern Hungary). Acta Palaeobotanica 51 (2): 127-179.

BarbaCKa M., PÁlfy J. \& SMith P. L. 2006. - Hettangian (Early Jurassic) plant fossils from Puale Bay (Peninsular terrane, Alaska). Review of Palaeobotany and Palynology 142: 33-46. https://doi. org/10.1016/j.revpalbo.2006.06.003

BARBACKA M., Ziaja J. \& WCISŁO-LURANiEC E. 2010. — Taxonomy and palaeoecology of the Early Jurassic macroflora from Odrowąz, central Poland. Acta Geologica Polonica 60 (3): 373-392.

Barbacka M., Bodor E., Jarzynka A., Kustatscher E., Pacyna G., Popa M. E., Scanu G. G., Thévenard F. \& Ziaja, J. 2014a. European Jurassic floras: statistics and paleoenvironmental proxies. Acta Palaeobotanica 54 (2): 173-195. https://doi.org/10.2478/ acpa-2014-0011

Barbacka M., Pacyna G., Feldman-Olszewska A., Ziaja J. \& Bodor E. 2014b. - Triassic-Jurassic flora of Poland; floristical support of climatic changes. Acta Geologica Polonica 64 (3): 281309. https://doi.org/10.2478/agp-2014-0015

Barbacka M., Pacyna G., Kocis A.T., JarzynKa A., Ziaja J. \& BODOR E. 2017. - Changes in terrestrial floras at the Triassic-Jurassic Boundary in Europe. Palaeogeography, Palaeoclimatology, Palaeoecology 480: 80-93. https://doi.org/10.1016/j.palaeo.2017.05.024

Bartiromo A. \& Barone Lumaga M. R. 2009. - Taxonomical revision of the collection of Jurassic plants from Roveré di Velo (Veneto, northern Italy) stored in the Palaeontological Museum of the University of Naples "Federico II". Bollettino della Societa Paleontologica Italiana 48 (1): 1-13.

Batten D. J. \& Koppelhus E. 1996. - Chapter 20D. Biostratigraphic significance of uppermost Triassic and Jurassic miospores in Northwest Europe, in JANSONIUS J. \& MCGREGOR D. C. (eds), Palynology: principles and applications. Publishers Press, Salt Lake City: 795-806.

BERGER A. C. 1832. - Die Versteinerungen der Fischer und Pflanzen im Sandsteine der Coburger Gegend. Coburg, 30 p.

Bomfleur B., PotT C. \& KerP H. 2011. - Plant assemblages from the Shafer Peak Formation (Lower Jurassic), north Victoria Land, Transantarctic Mountains. Antarctic Science 23 (2): 188208. https://doi.org/10.1017/S0954102010000866

BONIS N. R., KÜrSCHNER W. M. \& KRYSTYN L. 2009. — A detailed palynological study of the Triassic-Jurassic transition in key sections of the Eiberg Basin (Northern Calcareous Alps, Austria). Review of Palaeobotany and Palynology 156: 376-400. https://doi. org/10.1016/j.revpalbo.2009.04.003

Bose M. N. \& Manum S. B. 1990. - Mesozoic conifer leaves with "Sciadopitys-like" stomatal distribution. A re-evaluation based on fossils from Spitsbergen, Greenland and Baffin Island. Norsk Polarinstitutt Skrifter 192: 1-81.

Braun F. W. 1843. - Beiträge zur Urgeschichte der Pflanzen, in Münster G. G. (ed.), Beiträge zur Petrefaktenkunde 6: 1-33.

BrongniarT A. T. 1825. - Observations sur les végétaux fossiles renfermés dans les grès de Hoer en Scanie. Annales des Sciences Naturelles 4: 200-224.
BRONGNIART A. T. 1828a. - Histoire des végétaux fossiles ou recherches botaniques et géologiques sur les végétaux renfermés dans les diverses couches du globe. Vol. I. Dufour et d'Ocagne, Paris, 488 p.

Brongniart A. T. $1828 \mathrm{~b}$. - Prodrome d'une histoire des végétaux fossiles. Chez F. G. Levrault, Paris, 223 p.

BRONGNIART A. T. 1849. - Tableau des genres de végétaux fossils considérés sous le point de vue de leur classification botanique et de leur distribution géologique. Martinem, Paris, $127 \mathrm{p}$.

Chaloner W. \& Muir M. 1968. - Spores and Floras, in MurCHISON D. \& WeSTALL T. S. (eds), Coal and coal bearing strata. Oliver \& Boyd, Edinburgh: 127-146.

CleAl C. J. \& ReEs P. M. 2003. - The Middle Jurassic flora from Stonesfield. Oxfordshire, UK. Palaeontology 46 (4): 739-801. https://doi.org/10.1111/1475-4983.00319

Cleal C. J., ReEs P. M., Zijlstra G. \& Cantrill D. J. 2006. - A clarification of the type of Nilssoniopteris Nathorst (fossil Gymnospermophyta, Bennettitales). Taxon 55 (1): 219-222. https:// doi.org/10.2307/25065546

COMASCHI CARIA I. 1959. - Le piante fossili della Sardegna. Memorie VII. Rivista Italiana di Paleontologia e Stratigrafia 7: 1-176.

Costamagna L. G., Kustatscher E., Scanu G. G., Del Rio M., Pittau P. \& VAN Konijnenburg Van Cittert J. H. A. 2018. A palaeoenvironmental reconstruction of the Middle Jurassic of Sardinia (Italy) based on integrated palaeobotanical, palynological and lithofacies data assessment. Palaeobiodiversity and Palaeoenvironments 98 (1): 111-138. https://doi.org/10.1007/ s12549-017-0306-z

Couper R. A. 1953. - Upper Mesozoic and Cainozoic spores and pollen grains from New Zealand. New Zealand Geological Survey, Paleontological Bulletin 22: 1-77.

Couper R. A. 1958. - British Mesozoic microspores and pollen grains. A systematic and stratigraphic study. Palaeontographica Abt. B 103: 75-179.

COUPER R. A. 1964. - Spore-pollen correlation of the Cretaceous rocks of the Northern and Southern Hemispheres, in CrOss A. T. (ed.), Palynology in Oil Exploration. Society of Economic Paleontologists and Mineralogists Special Publication 11: 131-142.

CRANE P. R. 1986. - Form and Function in wind dispersed pollen, in Blackmore S. \& Ferguson I. K. (eds), Pollen and Spores: Form and Function. Academic Press, London \& Orlando: 179-202.

Crepet W., Friss E. M. \& NiXon K. C. 1991. - Fossil evidence for the evolution of biotic pollination. Philosophical Transactions of The Royal Society London B 333: 187-195. https://doi. org/10.1098/rstb.1991.0067

DayczaK-Calikowska K., Kopik J. \&, Marcinkiewicz T. 1997. Middle Jurassic, in MAREK S. \& PAJCHLOWA M. (eds), Epikontynentalny perm i mezozoik w Polsce. Prace Państwowego Instytutu Geologicznego: 236-282.

Dehbozorgi A., SajJadi F. \& Hashemi H. 2013. — Middle Jurassic palynomorphs of the Dalichai Formation, central Alborz Ranges, northeastern Iran: Paleoecological inferences. Science China Earth Sciences 56: 2107-2115. https://doi.org/10.1007/ s11430-013-4697-z

DEv S. 1961. - The fossil flora of the Jabalpur Series 3. Spores and pollen grains. The Palaeobotanist 8: 43-56.

Diéguez C., Hernández J. M. \& Pujalte V. 2009. — A fernbennettitalean floral assemblage in Tithonian-Berriasian travertine deposits (Aguilar Formation, Burgos-Palencia, N Spain) and its palaeoclimatic and vegetational implications. Journal of Iberian Geology 35 (2): 127-140.

Dieni I., Fisher J. C., Massari F., Salard-Cheboldaeff M. \& Vozenin-Serra C. 1983. - La succession de Genna Selole (Baunei) dans le cadre de la paléogéographie mésojurassique de la Sardaigne orientale. Memorie degli Instituti di Geologia e Mineralogia dell'Universita di Padova 36: 117-148.

DjordjeVIć-Milutinović D. 2010. - An overview of Paleozoic and Mesozoic sites with macroflora in Serbia. Bulletin of the Natural History Museum 3: 27-46. 
DoludenKo M. P. 1974. - On the relation of the genera Pachypteris, Thinnfeldia and Cycadopteris, in BOSE M. N. (ed.), Symposium on morphological and stratigraphical palaeobotany. Birbal Sahni Institute of Palaeobotany Special Publication 2: 8-16.

Doludenko M. P. \& SVAnidze C. I. 1964. - Some Jurassic Pterophyllum fronds of Ukraine and Georgia and their correlation with Indian species of this genus. International Geological Congres. XXII Session Reports of Soviet Geologists Problem 9 Gondwana. Nauka, Moscow: 111-122.

Dong C., Zhou Z., Zhang B., Wang Y. \& SHI G. 2019. — Umaltolepis and associated Pseudotorellia leaves from the Middle Jurassic of Yima in Henan Province, Central China. Review of Palaeobotany and Palynology 271: 104-111. https://doi.org/10.1016/j. revpalbo.2019.104111

DragASTAN O. \& BăRBULESCU A. 1977-1978. — La flore medio-Jurassique de la Dobrogea Centrale. Dări de Seamă ale Institutului de Geologie și Geofizică LXV: 77-98.

EDWARDS W. N. 1929. - The Jurassic flora of Sardinia. Annals and Magazine of Natural History 10: 385-394. https://doi. org/10.1080/00222932908673071

ERDTMAN G. 1948. - Did Dicotyledonous Plants exist in Early Jurassic Times? Geologiska Föreningens i Stockholm Förhandlingar 70: 265-271. https://doi.org/10.1080/11035894809454085

ETTINGSHAUSEN C. 1852. - Begrundung einiger neuen oder nich genau bekannten Arten der Lias- und Oolithflora. Abhandlungen der K. K. geologischen Reichsanstalt 1 (3): 1-10.

FLORIN R. 1936. - Die fossilen Ginkgophyten von Franz Joseph-Land nebst Erörterungen über vermeintliche Cordaitales mesozoischen Alters. I. Spezieller Teil, Palaeontographica Abt. B 81: 71-173.

FLORIN R. 1958. - On Jurassic taxads and conifers from NorthWesternEurope and Eastern Greenland. Acta Horti Bergiani 17 (10): 357-402.

GIVULESCU R. 1997. — La flore du lias inférieur d'Anina (Roumanie). Natura Silvaniae 1: 67-81.

GIVULESCU R. 1998. - Flora fosilli a Jurasicului inferior de la Anina. Editura Academiei Române, Bucureşti, 90 p.

Gomez B. 2002. - A new species of Mirovia (Coniferales, Miroviaceae) from the Lower Cretaceous of the Iberian Ranges (Spain). Cretaceous Research 23: 761-773. https://doi.org/10.1006/ cres.2002.1023

GRANDORI L. 1913a. - Intorno alla flora dei calcari grigi studiata da Achille De Zigno. Nota preliminare. Accademia Veneto-TrentinoIstriana di Padova 6: 143-148.

Grandori L. 1913b. - La Flora dei Calcari Grigi del Veneto, Parte Prima. Revisione e completamento dell'opera "Flora Fossilis Formationis Ooliticae" del Barone A. De Zigno. Memorie dell'Istituto Geologico della Regia Università di Padova 2: 1-112.

HABRYN R., BUŁA Z. \& NAWROCKI J. 2014. — The Kraków sector of the Kraków-Lubliniec Tectonic Zone in the light of data obtained from new boreholes of Trojanowice 2 and Cianowice 2. Biuletyn Instytutu Geologicznego 459: 45-59. https://doi. org/10.5604/08676143.1113063

HARRIS T. M. 1937. - The fossil flora of Scoresby Sound East Greenland. Part 5: Stratigraphic relations of the plant bed. Meddelelser om Gronland 112 (2): 1-114.

Harris T. M. 1949. - Notes on the Jurassic Flora of Yorkshire, 40-42. 40. Otozamites anglica (Seward) n. comb.; 41. The narrow-leaved Otozamites species; 42. Ptilophyllum hirsutum Thomas \& Bancroft and its differentiation from P. pecten (Phillips). Annals and Magazine of Natural History, London 12 (2): 275-299. https:// doi.org/10.1080/00222934908653988

HARRIS T. M. 1952. - Notes on the Jurassic Flora of Yorkshire, 52-54. 52. Haiburnia, a new genus of conifer shoots; 53. Bilsdalea dura gen. et sp. nov.; 54. Pagiophyllum rigidum (Phillips), n. comb. Annals and Magazine of Natural History, London 12 (5): 362-382. https://doi.org/10.1080/00222935208654303

HARRIS T. M. 1961. - The Yorkshire Jurassic flora. I. ThallophytaPteridophyta. British Museum (Natural History), London, 212 p.
Harris T. M. 1964. - The Yorkshire Jurassic flora. II. Caytoniales, Cycadales \& Pteridosperms. British Museum (Natural History), London $191 \mathrm{p}$

Harris T. M. 1969. - The Yorkshire Jurassic flora. III. Bennettitales. British Museum (Natural History), London, 186 p.

HARRIS T. M. 1977. - Notes on two of Raciborski's Jurassic ferns. Acta Palaeobotanica 18 (1): 3-12.

Harris T. M. 1979. - The Yorkshire Jurassic Flora. V: Coniferales. Trustees of the British Museum, London, $166 \mathrm{p}$

HARRIS T. M. \& Miller J. 1974. — The Yorkshire Jurassic flora. IV. Czekanowskiales. British Museum (Natural History), London.

Harris T. M. \& Millington W. 1974. - The Yorkshire Jurassic flora. IV. Ginkgoales. British Museum (Natural History), London, $150 \mathrm{p}$.

HARRIS T. M. 1977. - Notes of two of Raciborski's Jurassic ferns. Acta Palaeobotanica 18 (1): 3-12.

HaworTh M. \& McElWAin J. 2008. - Hot, dry, wet, cold or toxic? Revisiting the ecological significance of leaf and cuticular micromorphology. Palaeogeography, Palaeoclimatology, Palaeoecology 262: 79-90. https://doi.org/10.1016/j.palaeo.2008.02.009

HAWORTH M. \& MCELWAin J. 2009. - Reply to the comment on "Hot, dry, wet, cold or toxic? Revisiting the ecological significance of leaf cuticular micromorphology" by M. Haworth and J. C. McElwain [Palaeogeography, Palaeoclimatology, Palaeoecology 262 (2008) 79-90]. Palaeogeography, Palaeoclimatology, Palaeoecology 273: 209-211. https://doi.org/10.1016/j. palaeo.2008.11.008

Herngreen G. F. W. 1971. - Palynology of a wealden section (Lower Cretaceous) in the "Carrière de Longueville", the Boulonnais (France). Review of Palaeobotany and Palynology 12 (4) 271-302. https://doi.org/10.1016/0034-6667(71)90016-9

Hoelstad T. 1985. - Palynology of the uppermost Lower to Middle Jurassic strata on Bornholm, Denmark. Bulletin of the Geological Society of Denmark 34: 111-132.

Hughes N. F. 1976. - Palaeobiology of Angiosperm Origins. Cambridge University Press, Cambridge, $252 \mathrm{p}$.

ICHAS J. 1986. - Some spores and pollen grains from the Jurassic of the Kraków region. Acta Palaeobotanica 26 (1-2): 9-28.

JARZYNKA A. 2012. — The Middle Jurassic flora of the Grojec clays taxonomy and palaeoecology. PhD Thesis. W. Szafer Institute of Botany, Polish Academy of Sciences, Kraków (in Polish), 196 p.

JARZYNKA A. 2016. - Fossil flora of Middle Jurassic Grojec clays (southern Poland). Raciborski's original material reinvestigated and supplemented. II. Pteridophyta. Osmundales. Acta Palaeobotanica 56 (2): 183-221. https://doi.org/10.1515/acpa-20160018 https://doi.org/10.1515/acpa-2016-0018

JARZYNKA A. \& PACYNA G. 2015. — Fossil flora of Middle Jurassic Grojec clays (southern Poland). Raciborski's original material reinvestigated and supplemented. I. Sphenophytes. Acta Palaeobotanica 55 (2): 149-181. https://doi.org/10.1515/acpa-2015-0013

JOHANSSON N. 1922. — Die rhätische Flora der Kohlengruben bei Stabbarp und Skromberga in Schonen. Kungliga Svenska Vetenskapsakademiens Handlingar 63: 1-78.

JURKIEWICZOWA I. 1974. — Rozwój jury środkowej we wschodniej części obszaru krakowskiego. Z badań geologicznych regionu śląsko-krakowskiego. Biuletyn Instytutu Geologicznego 278: 201-239.

Kendall M. W. 1947. - On five Species of Brachyphyllum from the Jurassic of Yorkshire and Wiltshire. Annals and Magazine of Natural History 11 (14): 225-251. https://doi. org/10.1080/00222934708654632

KiritchKova A. I . \& Nosova N. V. 2009. - The Genus Pseudotorellia Florin (Ginkgoales): Taxonomic and Stratigraphic Aspects. Stratigraphy and Geological Correlation 17: 615-631. https://doi. org/10.1134/S0869593809060045

KirITCHKOVA A. I. \& NosOVA N. V. 2012. - Jurassic continental deposits of the Middle-Caspian Basin. 2: Facies, taphonomy, interregional correlations, flora (Pinophyta: Pteridospermae, Cycadales, Bennettitales, Ginkgoales, Czekanowskiales, Coniferales). Vnigri, 
St. Petersburg. [In Russian, English summary and descriptions of new taxa], $337 \mathrm{p}$.

KraSSER F. 1912. - Williamsonia in Sardinien. Sitzungsber. Akademie der Wissenschaften. Wien 121: 943-973.

Krasser F. 1913. — Die fossile Flora der Williamsonien Bergenden Juraschichten von Sardinien Anzeiger. Akademischer Anzeiger 4: 31-36.

KRASSER F. 1915. - Männliche Williamsonien aus dem Sandsteinschiefer des unteren Lias von Steierdorf im Banat. Denkschriften der Kaiserlichen Akademie der Wissenschaften. Mathematisch-naturwissenschaftliche. Klasse 93: 1-14.

KRASSER F. 1920. — Doggerflora von Sardinien. Sitzungsber. Akademie der Wissenschaften. Wien 129: 1-26.

Krings M., Klavins S. D., DiMichele W. A., Axsmith B. J., Kerp H., \& TAYLOR T. N. 2005. — Epidermal anatomy of Glenopteris splendens Sellards nov. emend., an enigmatic seed plant from the Lower Permian of Kansas (U.S.A.). Review of Palaeobotany and Palynology 136: 159-180. https://doi.org/10.1016/j. revpalbo.2005.07.002

Krupnik J., Ziaja J., Barbacka M., Feldman-Olszewska A. \& JARZYNKA A. 2014. - A palaeoenvironmental reconstruction based on palynological analyses of Upper Triassic and Lower Jurassic sediments from the Holy Cross Mountains region. Acta Palaeobotanica 54 (1): 35-65. https://doi.org/10.2478/acpa-2014-0006

Kustatscher E., Manfrin S., Mietto P., Posenato R. \& Roghi G. 2006. - New biostratigraphic data on Anisian (Middle Triassic) palynomorphs from the Dolomites, Italy. Review of Palaeobotany and Palynology 140: 79-90. https://doi.org/10.1016/j. revpalbo.2006.03.003

Kustatscher E., Wachtler M. \& VAn Konijnenburg-VAn CitTERT J. H. A. 2010a. - Lycophytes from the Middle Triassic (Anisian) locality Kühwiesenkopf (Monte Prá Della Vacca) in the Dolomites (Northern Italy). Palaeontology 53 (3): 595-626. https://doi.org/10.1111/j.1475-4983.2010.00948.x

Kustatscher E., Van Konijnenburg-Van CitTert J. H. A. \& RoGHI G. 2010b. - Macrofloras and palynomorphs as possible proxies for palaeoclimatic and palaeoecological studies: A case study from the Pelsonian (Middle Triassic) of Kühwiesenkopf/ Monte Prà della Vacca (Olang Dolomites, N-Italy). Palaeogeography, Palaeoclimatology, Palaeoecology 290: 71-80. https://doi. org/10.1016/j.palaeo.2009.07.001

Kustatscher E., Heunisch C. \& Van Konijnenburg-Van CitTerT J. H. A. 2012. - Taphonomical implications of the Ladinian megaflora and palynoflora of Thale (Germany). Palaios 27 (11): 753-764. https://doi.org/10.2110/palo.2011.p11-090r

KÜRSCHNER W. M., BONIS N. R. \& KRYSTYN L. 2007. — Carbon-isotope stratigraphy and palynostratigraphy of the Triassic-Jurassic transition in the Tiefengraben section - Northern Calcareous Alps (Austria). Palaeogeography, Palaeoclimatology, Palaeoecology 244: 257-280. https://doi.org/10.1016/j.palaeo.2006.06.031

LaKHANPAl R. N., MAHEShWARI H. K. \& AWASTHI N. 1976. A catalogue of Indian fossil plants. Birbal Sahni Institute of Palaeobotany, Lucknow, 318 p.

LAMMONS J. M. 1969. - The palynology and paleoecology of the Pierre Shale (Campanian - Maastrichtian) of northwestern Kansas and Environs. PhD Thesis. Michigan State University, 260 p.

Lemoigne Y. 1968. — Paléoflore à Cupressales dans le Trias Rhetien du Cotentin. Comptes Rendus de l'Académie des Sciences 264: 715-718.

LUND J. J. 1977. - Rhaetic to Lower Liassic palynology of the onshore south-eastern North Sea Basin. Geologic survey of Denmark II 109: 1-129.

LundBlad A. B. 1950. - Studies in the Rhaeto-Liassic floras of Sweden. I. Pteridophyta, Pteridospermae and Cycadophyta from the mining district of NW Scania. Kungliga Svenska Vetenskapsakademiens Handlingar Fjärde serien 1 (8): 1-82.

MAKAREWICZÓWNA A. 1928. - Étude sur la flore fossile du lias inférieur des environs d'Ostrowiec. Travaux de la Société des Science et des Letters de Wilno, Travaux de L'Institut de Géologie de l'Université de Wilno 4 (3): 1-49 (in Polish with French summary).

Manum S. B., Bose M. N. \& Vigran J. O. 1991. - The Jurassic flora of Andoya, northern Norway. Review of Palaeobotany and Palynology 68: 233-256. https://doi.org/10.1016/00346667(91)90026-Y

MARCINKIEWICZ T. 1980. - Jurassic megaspores from Grojec near Kraków. Acta Palaeobotanica 21 (1): 37-60.

MARKOWIaK M. 2014. - Przejawy mineralizacji kruszcowej w skałach nawierconych otworami Trojanowice 2 i Cianowice 2. Biuletyn Instytutu Geologicznego 459: 83-92. https://doi. org/10.5604/08676143.1113072

MARTINOV I. 1820. - Techno-botanical dictionary. Imperial Russian Academy, St. Petersburg, 682 p.

MATYJA B. A. \& Zı́́ŁKOWSKI P. 2014. — Stratygrafia i zróżnicowanie facjalne jury górnej na przykładzie profili otworów wiertniczych Cianowice 2 i Trojanowice 2 (pogranicze Wyżyny Olkuskiej i Rowu Krzeszowickiego). Biuletyn Instytutu Geologicznego 459: 93-108. https://doi.org/10.5604/08676143.1113073

MAYs C. 2015. - A Late Cretaceous (Cenomanian-Turonian) south polar palynoflora from the Chatham Islands, New Zealand. Memoirs of the Association of Australasian Palaeontologists 47: 1-92.

Morbey S. J. 1975. - The palynostratigraphy of the Rhaetian stage, Upper Triassic in the Kendelbachgraben, Austria. Palaeontographica Abt. B 152 (1-3): 1-75.

MORRIS J. 1840. - Memoir to illustrate a Geological Map of Cutch. Transaction of Geological Society of London 2: 289-329.

MORRIS J. 1841. - Remarks upon the recent and fossil Cycadeae. Annals and Magazine of Natural History Series 1, 7: 110-120.

MöLler H. 1902. - Bornholms fossila flora (Rhät och Lias) Gymnospermer. Kungliga Svenska Vetenskapsakademiens Handlingar 36 (6): 1-56.

NATHORST A. G. 1878a. - Beitrage zur fossilen Flora Schwedens. Über winige fossile Pflanzen von Palsjö in Schonen. E. Schweizerbart'sche Verlagshandlung (E. Koch), Stuttgart, 34 p.

NATHORST A. G. 1878b. - Om floran i Skånes kolförande bildningar. II. Floran vid Höganäs och Helsinborg. Kungliga Svenska Vetenskapsakademiens Handlingar 16 (7): 4-53.

NATHORST A. G. 1878c. — Floran vid Högenäs och Helsingborg. Kungliga Svenska Vetenskapsakademiens Handlingar 16: 1-53.

NATHORST A. G. 1880. — Berättelse, afgifven tili Kongl. Vetenskaps-Akademien, om en med understöd af allmänna medel utförd vetenskaplig resa till England. Öfversigt af Kongliga Vetenskapsakademiens forhandlingar 37 (5): 23-84.

NATHORST A. G. 1886. — Om floran i Skånes kolförande bildningar. Sveriges Geologiska Undersökning, Serie C 85: 83-131.

Nathorst A. G. 1909. — Über die Gattung Nilssonia Brongn. mit besonderer Berücksichtigung schwedischer Arten. Kungliga Svenska Vetenskapsakademiens Handlingar 43: 3-37.

Nguyen T. T., Bocherens H., Mariotti A., Baudin F., Pons D., Broutin J., Derenne S. \& Largeau C. 1999. — Ecological distribution of Cenomanian terrestial plants based on $13 \mathrm{C} / 12 \mathrm{C}$ ratios. Palaeogeography, Palaeoclimatology, Palaeoecology 145: 79-93. https://doi.org/10.1016/S0031-0182(98)00092-3

NiLsSON T. 1958. — Über das Vorkommen eines mesozoischen Sapropelgesteins in Schonen. Publications from the Institutes of Mineralogy, Palaeontology and Quaternary Geology, University of Lund 53: 1-112.

NORSTOG K. 1987. - Cycads and the origin of insect pollination. American Scientist 75: 270-279.

Nosova N. \& GolovNEVA L. 2018. — Phoenicopsis (Leptostrobales) and Pseudotorellia (Ginkgoales) from the Cretaceous of North Asia. Cretaceous Research 86: 1-14. https://doi.org/10.1016/j. cretres.2018.03.001

Nosova N. \& WCisŁo-Luraniec E. 2007. — A reinterpretation of Mirovia Reymanówna (Coniferales) based on the reconsideration of the type species Mirovia szaferi Reymanówna from the Polish Jurassic. Acta Palaeobotanica 47: 359-377. 
OrŁowsKA-ZwOlińSKA T. 1966. - Dolnoliasowy wiek warstw wielichowskich na tle badań sporowo-pyłkowych na Niżu Polskim (summary: Lower Liassic age of the Wielichowo beds in the light of spore-and-pollen analysis, Polish Lowland). Kwartalnik Geologiczny 10 (4): 1003-1047.

OrŁOWSKA-ZWOLIŃSKA T. 1983. - Palinostratygrafia epikontynentalnych osadów wyższego triasu w Polsce. Prace Instytutu Geologicznego 104: 1-89.

PACYNA G. 2013. - Critical review of research on the Lower Jurassic flora of Poland. Acta Palaeobotanica 53 (2): 141-163. http:// doi.org/10.2478/acpa-2013-0015

Pedersen K. R. \& LUND J. J. 1980. — Palynology of the plant-bearing Rhaetian to Hettangian Kap Stewart formation, Scoresby Sund, East Greenland. Review of Palaeobotany and Palynology 281: 1-69. https://doi.org/10.1016/0034-6667(80)90022-6

Philippe M., Thévenard F., Barale G., Ferry S. \& Guignard G. 1998. - Middle Bathonian floras and phytocoenoses of France. Palaeogeography, Palaeoclimatology, Palaeoecology 143 (1-3): 135158. https://doi.org/10.1016/S0031-0182(98)00075-3

PHILlips J. 1829. - Illustrations of the geology of Yorkshire, or, a description of the strata and organic remains of the Yorkshire Coast: Accompanied by a geological map, sections, and plates of the fossil plants and animals. Thomas Wilson and Sons, York, 253 p.

PHILLIPS J. 1875. - Illustrations of the geology of Yorkshire, or, a description of the strata and organic remains. Part I, The Yorkshire Coast. R. Etheridge, London, 354 p.

PIEŃKOWSKI G. 2014. — Profil sedymentologiczny przedkelowejskich (jurajskich) utworów silikoklastycznych w otworze badawczym Cianowice 2 (okolice Krakowa). Biuletyn Instytutu Geologicznego 459: 147-156. https://doi.org/10.5604/08676143.1113174

PococK S. A. J. 1970. - Palynology of the Jurassic sediments of Western Canada, Part 1. Terrestrial species. Palaeontographica. Abt. B 130 (1): 12-136.

POPA M. E. 1997a. - Liassic ferns from the Steierdorf Formation, Anina, Romania, in Herngreen G. F. W. (ed.), Proceedings 4th European Palaeobotanical and Palynological Conference. Mededelingen Nederlands Instituut Toegepaste Geowetenschappen TNO 58: 139-148.

Popa M. E. 1997b. - Corystospermal pteridosperms in the Liassic deposits of Romania. Acta Palaeontologica Romaniae 1997 (1): 81-87.

PopA M. E. 1998. - The Liassic continental flora of Romania: Systematics, Stratigraphy and Paleoecology. Acta Botanica Horti Bucurestensis 1997-1998: 177-184.

Popa M. E. 2000a. - Early Jurassic land flora of the Getic Nappe. $\mathrm{PhD}$ Thesis. Archives of the University of Bucharest, Bucharest, $258 \mathrm{p}$.

POPA M. E. 2000b. - Aspects of Romanian Early Jurassic palaeobotany and palynology. Part III. Phytostratigraphy of the Getic Nappe. Acta Palaeontologica Romaniae 2: 377-386.

Popa M. E. 2009. — Late Palaeozoic and Early Mesozoic continental formations of the Reşița Basin. Editura Universitii din Bucuresti, Bucharest, $197 \mathrm{p}$.

POPA M. E. 2014. - Early Jurassic bennettitalean reproductive structures of Romania, in Kustatscher E., VAN DEN Hoek Ostende L.W. \& Kerp H. (eds), Green planet - 400 million years of terrestrial floras. Papers in honour of J.H.A. van Konijnenburg-van Cittert. Palaeobiodiversity and Palaeoenvironments 94 (2): 327-362. https://doi.org/10.1007/s12549-014-0165-9

Popa M. E. \& McElvain J. C. 2009. - Bipinnate Ptilozamites nilssonii from Jameson Land and new considerations on the genera Ptilozamites Nathorst 1878 and Ctenozamites Nathorst 1886. Review of Palaeobotany and Palynology 153: 386-393. https://doi. org/10.1016/j.revpalbo.2008.10.007

Popa M. E. \& VAN Konijnenburg-Van CitTert J. H. A. 2006. Aspects of Romanian Early - Middle Jurassic palaeobotany and palynology. Part VII. Successions and floras. Progress in Natural Sciences 16: 203-212.
PotoniÉ R. 1956. — Synopsis der Gattungen der Sporae dispersae. I.Teil: Sporites. Beihefte zum Geologischen Jahrbuch 23: 1-103.

PotT C. \& McLoughlin S. 2009. - Bennettitalean foliage in the Rhaetian-Bajocian (latest Triassic-Middle Jurassic) floras of Scania, southern Sweden. Review of Palaeobotany and Palynology 158 (12): 117-166. http://doi.org/10.1016/j.revpalbo.2009.08.004

PotT C. \& VAn KonijnenburG-VAn CitTert J. H. A. 2017. The type specimen of Nilssoniopteris solitaria (Phillips 1829) Cleal et P.M. Rees 2003 (Bennettitales). Acta Palaeobotanica 57 (2): 177-184. http://doi.org/10.1515/acpa-2017-0008

Pott C., Krings M. \& Kerp H. 2008. - The Carnian (Late Triassic) flora from Lunz in Lower Austria: Paleoecological considerations. Palaeoworld 17 (3-4): 172-182.

Pott C., Schmeissner S., DÜtsch G., \& VAn Konijnenburgvan Cittert J. H. A. 2016. - Bennettitales in the Rhaetian flora of Wüstenwelsberg, Bavaria, Germany. Review of Palaeobotany and Palynology 232: 98-118. https://doi.org/10.1016/j. revpalbo.2016.04.010

RACIBORSKI M. 1894. - Flora kopalna ogniotrwałych glinek krakowskich. Część I. Rodniowce (Archaegoniatae). Pamiętnik Wydziatu matematyczno-przyrodniczego Akademii Umiejętności 18: 1-101.

REYMANÓWNa M. 1963a. - Review of investigations on Polish Jurassic floras. Acta Palaeobotanica 4 (2): 3-8.

REYMANÓWNA M. 1963b. - The Jurassic flora from Grojec near Cracow in Poland. Part I. Acta Palaeobotanica 4 (2): 9-48.

Reymanówna M. 1977. - On Bilsdalea dura Harris (Coniferae) from the Jurassic of Poland. Acta Palaeobotanica 18: 13-18.

ReYMANÓWNa M. 1985. - Mirovia szaferi gen. et sp. nov. (Ginkgoales) from the Jurassic of the Kraków region, Poland. Acta Palaeobotanica 25 (1-2): 3-12.

Sajjadi F., Hashemi H. \& Dehbozorgi A. 2007. — Middle Jurassic Palynomorphs of the Kashafrud Formation, Koppeh Dagh Basin, Northeastern Iran. Micropaleontology 53 (5) : 391-408.

Salard-CheboldaefF M. \& Vozenin-Serra C. 1984. - Palynoflore et taphoflore jurassiques de Sardaigne centre-orientale. Revue de Paléobiologie 1 (1): 193-197.

SAPORTA G. 1873-1891. - Paléontologie française (Plantes Jurassiques). Ser. 2, G. Masson, Paris, vol. I, 506 p., II, 352 p., III, 672 p., IV 548 p.

Scanu G. G., Kustatscher E. \& Pittau P. 2012. — The Jurassic plant fossils of the Lovisato Collection: preliminary notes. Bollettino della Societa Paleontologica Italiana 51 (2): 71-84. https:// doi.org/10.4435/BSPI.2012.9

Scanu G. G., Kustatscher E. \& Pittau P. 2012. — The Jurassic plant fossils of the Lovisato Collection: preliminary notes. Bollettino della Societa Paleontologica Italiana 51 (2): 71-84.

Scanu G. G., Kustatscher E. \& Pittau P. 2015. — The Jurassic flora of Sardinia - A new piece in the palaeobiogeographic puzzle of the Middle Jurassic. Review of Palaeobotany and Palynology 218: 80-105. https://doi.org/10.1016/j.revpalbo.2014.08.008

SCHENK A. 1887. — Fossile pflanzen aus der Albourskette. Bibliotheca Botanica Stuttoart 6: 1-12.

SCHIMPeR W. P. 1870. — Traité de Paléontologie Végétale. Tome II, Baillière et Fils, Paris, 968 p.

SCHULZ E. 1967. — Sporenpaläontologische Untersuchungen rätoliassischer Schichten im Zentralteil des Germanischen Beckens. Paläontologische Abhandlungen B, Paläobotanik 2 (3): 541-633.

SCHulz E. \& MAI D. H. 1966. — Erlauterungen zur Tabelle der stratigraphischen Verbreitung der Sporen und Pollen in Lias und Dogger. Abhandlungen des Zentralen Geologischen Instituts 8: $21-34$

SCHULze F. 1855. - Über das Vorkommen wohlerhaltener zellulose in Braunkohle und Steinkohle. Berliner Königlichen Akademie der Wissenschaften 21: 676-678.

SemaKa A. 1962a. - Flora Liasic de la Anina (Banat). Anuarul Comitetului Geologic 32: 527-569.

SemaKa A. 1962b. - Flora Liasic de la Doman (Banat). Dri de Seamale edinelor Comitetului Geologic 43: 125-242. 
SemaKa A. 1965. - Zur kenntnis der Nilssonia orientalis - Flora in den Südkarpathen. Acta Palaeobotanica 6 (2): 27-39.

SEMAKA A. 1970. - Geologisch-Paleobotanische Untersuchungen in S.O. Banaten Danubikum. Memorii 11: 1-79.

SEWARD A. C. 1900. - The Jurassic flora I. The Yorkshire coast. Catalogue of the Mesozoic Plants in the Department of Geology, British Museum (Natural History) 3: 1-341.

Shi G., Herrera F., Herendeen P. S., Leslie A. B., IchinNOROV N. \& TAKahashie M. \& Crane P. R. 2018. - Leaves of Podozamites and Pseudotorellia from the Early Cretaceous of Mongolia: stomatal patterns and implications for relationships Journal of Systematic Palaeontology 16: 111-137. https://doi.org /10.1080/14772019.2016.1274343

Slater S. M. \& Wellman C. H. 2015. - A quantitative comparison of dispersed spore/ pollen and plant megafossil assemblages from a Middle Jurassic plant bed from Yorkshire, UK. Paleobiology 41: 640-660. https://doi.org/10.1017/pab.2015.27

Slater S. M. \& Wellman C. H. 2016. - Middle Jurassic vegetation dynamics based on quantitative analysis of spore/pollen assemblages from the Ravenscar Group, North Yorkshire, UK. Palaeontology 59 (2): 305-328. https://doi.org/10.1111/pala.12229

SZYDE€ Z. \& SZYDEŁ R. 1981. - Profil utworów liasu na obszarze Lubelskiego Zagłębia Węglowego. Przegląd Geologiczny 11:568-571.

Thévenard F., Gomez B. \& Daviero-Gomez V. 2005. - Xeromorphic adaptations of some Mesozoic gymnosperms. A review with palaeoclimatological implications. Comptes Rendus Palevol 4: 67-77. https://doi.org/10.1016/j.crpv.2004.11.012

TORNQUIST A. 1904. - Beitrage zur Geologie der Westlichen Mittelmeerland. In Die Pflanzen des Mittelsjurassischen Sandsteines Ostsardinien. Neues Jahrbuch für Mineralogie, Geologie und Paläontologie 20: 149-158.

VAJDA V. 2001. - Aalenian to Cenomanian terrestrial palynofloras of SW Scania, Sweden. Acta Palaeontologica Polonica 46 (3): 403-426.

VAKHRAMEEV V. A. 1991. — Jurassic and Cretaceous floras and climates of the Earth. Cambridge University Press, Cambridge, 319 p.

VAN DER EEM J. G. L. A. 1983. - Aspects of Middle and Late Triassic Palynology. 6. Palynological investigations in the Ladinian and Lower Karnian of the Western Dolomites, Italy. Review of Palaeobotany and Palynology 39: 189-300. https://doi.org/10.1016/00346667(83)90016-7

VAN KONIJNENBURG-VAN CiTTERT J. H. A. 2002. — Ecology of some Late Triassic to Early Cretaceous ferns in Eurasia. Review of Palaeobotany and Palynology 119: 113-124. https://doi.org/10.1016/ S0034-6667(01)00132-4

Van Konijnenburg-Van Cittert J. H. A. \& Morgans H. S. 1999. - The Jurassic Flora of Yorkshire. Palaeontological Association, London, $134 \mathrm{p}$.

Van Konijnenburg-Van Cittert J. H. A. \& Van der Burgh J. 1989. - The fora from the Kimmeridgian (Upper Jurassic) of Culgower, Sutherland, Scotland. Review of Palaeobotany and Palynology 61: 1-51. https://doi.org/10.1016/0034-6667(89)90060-2

Van Konijnenburg-Van Cittert J. H. A., Pott C., Cleal C.J. \& ZIJLSTRA G. 2017. - Differentiation of the fossil leaves assigned to Taeniopteris, Nilssoniopteris and Nilssonia with a comparison to similar genera. Review of Palaeobotany and Palynology 237: 100106. https://doi.org/10.1016/j.revpalbo.2016.11.009
Van Konijnenburg-Van Cittert J. H. A., Pott C., SChmeissner S., DütsCH G. \& KustatsCher E. 2018. — Seed ferns and cycads in the Rhaetian flora of Wüstenwelsberg, Bavaria, Germany. Review of Palaeobotany and Palynology 258: 190-214. https:// doi.org/10.1016/j.revpalbo.2018.08.005

WANG Y.-D. 2002. - Fern ecological implications from the Lower Jurassic in Western Hubei, China. Review of Palaeobotany and Palynology 119: 125-141. https://doi.org/10.1016/S00346667(01)00133-6

Wang Y.-D., Ni Q., JiAng Z.-K. \& Tian N. 2008. — Diversity variation and tempo-spatial distribution of Otozamites (Bennettitales) in the Mesozoic of China. Palaeoworld 17: 222-234. https://doi.org/10.1016/j.palwor.2008.10.003

WATSON J. \& HARRISON N. A. 1998. - Abietites linkii (Roemer) and Pseudotorellia heterophylla Watson: coniferous or ginkgoalean? Cretaceous Research 19: 239-277. https://doi.org/10.1006/ cres. 1997.0112

WATSON J. \& SinCOCK C. A. 1992. — Bennettitales of the English Wealden. Palaeontographical Society, London, $228 \mathrm{p}$.

WCISŁO-LuRANiEC E. 1985. - New details of leaf structure in Bilsdalea dura Harris (Coniferae) from the Jurassic of Kraków, Poland. Acta Palaeobotanica 25: 13-20.

WEBER R. 1968. - Die fossile Flora der Rhät-Lias Übergangsschichten von Bayreuth (Oberfranken) unter besonderer Berücksichtigung der Coenologie. Erlanger Geologische Abhandlungen 72: 1-73.

WeISS M. 1989. — Die Sporenfloren aus Rät und Jura SüdwestDeutschlands und ihre Beziehung zur Ammoniten-Stratigraphie. Palaeontografica Abt. B 125 (1-6): 1-168.

WesLeY A. 1956. - Contribution to the knowledge of the flora of the Grey Limestone of Veneto, I. Memorie Università Padova 19: 1-69.

WesLey A. 1958. - Contribution to the knowledge of the flora of the Grey Limestone of Veneto, II. Memorie Università Padova 21: $1-57$.

WESLEY A. 1966. - The fossil flora of the grey limestones of Veneto, Northern Italy and its relationships to the other European floras of similar age. Palaeobotanist 14 (1-3): 124-130.

Wesley A. 1974. - On the bennettitalean remains from the Lias of northern Italy, in BOSE M. N. (ed.), Symposium on morphological and stratigraphical palaeobotany. Birbal Sahni Institute of Palaeobotany, Lucknow, Special Publication 2: 66-71.

De Zigno A. 1856-68. - Flora Fossilis Formationis Oolithicae. Le piante fossili dell'Oolite. Vol. 1. Tipografia del seminario, Padova, 223 p.

DE ZIGNO A. 1873-85. - Flora Fossilis Formationis Oolithicae. Le piante fossili dell'Oolite. Vol. 2. Tipografia del seminario, Padova, 203 p.

ŻABA J. 1999. - The structural evolution of Lower Palaeozoic succession in the Upper Silesia and Małopolska block border zone (Southern Poland). Prace Państwowego Instytutu Geologicznego 166: 162 (in Polish with English summary).

ŻELAźniewicz A., Obec-DZiedzic T., Fanning C. M., Protas A. \& MusZYŃSKi A. 2016. — Late Carboniferous-Early Permian events in the Trans-European Suture Zone: tectonic and acid magmatic evidence from Poland. Tectonophysics 675: 227-243. https://doi. org/10.1016/j.tecto.2016.02.040 


\section{APPENDIX}

APPENDIX 1. - Appearance of macro- and microremains in the Cianowice borehole. Frequency of sporomorphs is given as average number of sporomorphs per slide.

\begin{tabular}{|c|c|c|c|c|c|c|c|}
\hline Depth (m) & Macroflora taxon & Microflora taxon & $\begin{array}{l}\text { Botanical affinity } \\
\text { of microflora }\end{array}$ & Frequency & $\begin{array}{l}\text { Number of } \\
\text { fragments }\end{array}$ & 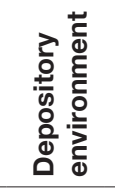 & 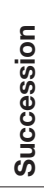 \\
\hline \multirow[t]{2}{*}{245.3} & & $\begin{array}{l}\text { Eucommiidites troedssonii } \\
\text { Erdtman }\end{array}$ & Erdtmanithecales & 2 & & $\frac{\frac{5}{\pi}}{2}$ & $\begin{array}{l}. \frac{0}{0} \\
\frac{0}{4}\end{array}$ \\
\hline & & Vitreisporites pallidus Couper & seed ferns (Caytoniales) & 1 & &.$\overline{\widetilde{\sigma}}$ & ఝ \\
\hline $245.6(1)$ & Pseudotorellia grojecensis & & & & 2 & 引 & U్ \\
\hline \multirow[t]{3}{*}{$246.0(2)$} & Pachypteris rhomboidalis & & & & 1 & & ๗ \\
\hline & Otozozamites parallelus & & & & 1 & & \\
\hline & Pseudotorellia grojecensis & & & & 1 & & \\
\hline \multirow[t]{3}{*}{$246.9(1)$} & Otozamites mimetes & & & & 1 & & \\
\hline & Pseudotorellia samylinae & & & & 1 & Channel & \\
\hline & Pterophyllum thomasii & & & & 1 & & \\
\hline \multirow[t]{7}{*}{$247.3(2)$} & Anomozamites nilssonii & & & & 4 & $\cdot \frac{\complement}{\bar{\sigma}}$ & \\
\hline & Nilssoniopteris solitaria & & & & 1 & 응 & \\
\hline & Ptilophyllum sirkennethii & & & & 1 & $\overline{\bar{\sigma}}$ & \\
\hline & Pterophyllum thomasii & & & & 1 & 引 & \\
\hline & Ptilophyllum cf. okribense & & & & 2 & & \\
\hline & Pseudotorellia grojecensis & & & & 1 & & \\
\hline & Pseudotorellia sp. & & & & 1 & & \\
\hline \multirow[t]{3}{*}{247.7} & & $\begin{array}{l}\text { Deltoidospora/Dictyophyllidites/ } \\
\text { Cyathidites spp. }\end{array}$ & $\begin{array}{l}\text { ferns (Dicksoniaceae, } \\
\text { Cyatheaceae, } \\
\text { Dipteridaceae, } \\
\text { Matoniaceae) }\end{array}$ & 8 & & $\begin{array}{l}\bar{\Phi} \\
\text { c } \\
\text { ত } \\
\frac{c}{U}\end{array}$ & \\
\hline & & Cerebropollenites sp. & conifers (Taxodiaceae) & 1 & & & \\
\hline & & bisaccate pollen grains & seed ferns or conifers & 6 & & & \\
\hline \multirow[t]{7}{*}{248.7} & & $\begin{array}{l}\text { Deltoidospora/Dictyophyllidites/ } \\
\text { Cyathidites spp. }\end{array}$ & $\begin{array}{l}\text { ferns (Dicksoniaceae, } \\
\text { Cyatheaceae, } \\
\text { Dipteridaceae, } \\
\text { Matoniaceae) }\end{array}$ & 11 & & & \\
\hline & & Contignisporites sp. & ferns (Pteridaceae) & 1 & & & \\
\hline & & Sestrosporites sp. & , & 1 & & & \\
\hline & & Eucommiidites sp. & Erdtmanithecales & 1 & & & \\
\hline & & Cerebropollenites & conifers (Taxodiaceae) & 1 & & & \\
\hline & & macroverrucosus (Thiergart) & & & & & \\
\hline & & Schulz & & & & & \\
\hline \multirow[t]{9}{*}{249.0} & & Lycopodiacidites sp. & Lycophyta & 2 & & & \\
\hline & & $\begin{array}{l}\text { Deltoidospora/Dictyophyllidites/ } \\
\text { Cyathidites spp. }\end{array}$ & $\begin{array}{l}\text { ferns (Dicksoniaceae, } \\
\text { Cyatheaceae, } \\
\text { Dipteridaceae, } \\
\text { Matoniaceae) }\end{array}$ & 17 & & & \\
\hline & & Baculatisporites spp. & ferns (Osmundaceae) & 5 & & & \\
\hline & & Osmundacidites wellmanii Couper & ferns (Osmundaceae) & 3 & & & \\
\hline & & Sestrosporites sp. & $?$ & 1 & & & \\
\hline & & Eucommiidites sp. & Erdtmanithecales & 3 & & & \\
\hline & & Cerebropollenites & conifers (Taxodiaceae) & 4 & & & \\
\hline & & macroverrucosus (Thiergart) & & & & & \\
\hline & & Schulz & & & & & \\
\hline \multirow[t]{6}{*}{$249.4(4)$} & Cladophlebis sp. & & & & 1 & & \\
\hline & Pachypteris rhomboidalis & & & & 1 & & \\
\hline & Ptilozamites cycadea & & & & 1 & & \\
\hline & Otozamites parallelus & & & & 3 & & \\
\hline & Pseudotorellia samylinae & & & & 1 & & \\
\hline & Pseudotorellia sp. & & & & 1 & & \\
\hline \multirow[t]{7}{*}{250.1} & & Lycopodiacidites sp. & Lycophyta & 1 & & 을 & \\
\hline & & Deltoidospora/Dictyophyllidites/ & ferns (Dicksoniaceae, & 17 & & 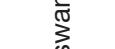 & $\frac{\overline{0}}{9}$ \\
\hline & & Cyathidites spp. & $\begin{array}{l}\text { Cyatheaceae, } \\
\text { Dipteridaceae, } \\
\text { Matoniaceae ) }\end{array}$ & & & 品 & $\begin{array}{l}\infty \\
\text { d } \\
0 \\
\text { क }\end{array}$ \\
\hline & & Apiculatisporites sp. & $?$ & 2 & & $\frac{0}{0}$ & \\
\hline & & Baculatisporites spp. & ferns (Osmundaceae) & 6 & & ฮ & \\
\hline & & Osmundacidites wellmanii Couper & $\begin{array}{l}\text { ferns (Osmundaceae) } \\
\text { ferns (Marattiaceae) }\end{array}$ & 2 & & & \\
\hline & & Maratiisporites scabratus Couper & & 8 & & & \\
\hline
\end{tabular}




\section{2 (4) Pachypteris rhomboidalis Otozamites mimetes Otozamites parallelus Pseudotorellia grojecensis Pseudotorellia samylinae \\ 250.3 (1) Pachypteris rhomboidalis Pseudotorellia grojecensis 250.5 (1) Ptilophyllum pecten 251.3 Pterophyllum thomasii}

255.7 (2) Pterophyllum cf. aequale Microflora taxon

Botanical affinity

Eucommiidites minor Groot \& Penny

Eucommiidites troedssonii of microflora Frequency fragments

Erdtmanithecales

Erdtman

Eucommiidites sp.

Vitreisporites pallidus Couper Cerebropollenites macroverrucosus (Thiergart) Schulz

Cerebropollenites sp.

Araucariacites sp.

bisaccate pollen grains

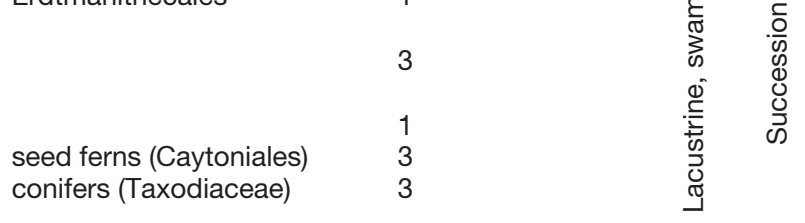

Deltoidospora/Dictyophyllidites/ Cyathidites spp.

ferns (Dicksoniaceae, seed ferns or conifers $\quad 14$

Cyatheaceae,

Dipteridaceae,

Matoniaceae)

Klukisporites variegatus Couper Deltoidospora/Dictyophyllidites/ Cyathidites spp.

ferns (Schizaeaceae)

ferns (Dicksoniaceae,

Cyatheaceae,

Dipteridaceae,

Baculatisporites spp.

Matoniaceae)

Klukisporites variegatus Couper

Contignisporites sp.

ferns (Osmundaceae) 2

ferns (Schizaeaceae) 38

ferns (Pteridaceae) 3

Eucommiidites sp.

Erdtmanithecales

Callialasporites trilobatus (Balme)

conifers (Araucariaceae)

5

Classopollis torosus (Reissinger)

Couper

Vitreisporites pallidus Couper

conifers

(Cheirolepidiaceae)

seed ferns (Caytoniales)

3

14

bisaccate pollen grains

seed ferns or conifers

Cycadolepis sp.

Bilsdalea dura

Brachyphyllum stemonium

255.8 (5) Cladophlebis sp.

Pachypteris rhomboidalis

Otozamites parallelus

Pterophyllum thomasii

Pterophyllum cf. aequale

Ptilophyllum cf. okribense

Cycadolepis sp.

Pseudotorellia grojecensis

Pseudotorellia samylinae

Bilsadalea dura

Mirovia szaferii

Brachyphyllum stemonium

Ctenis sp.

Baculatisporites spp.

Klukisporites variegatus Couper

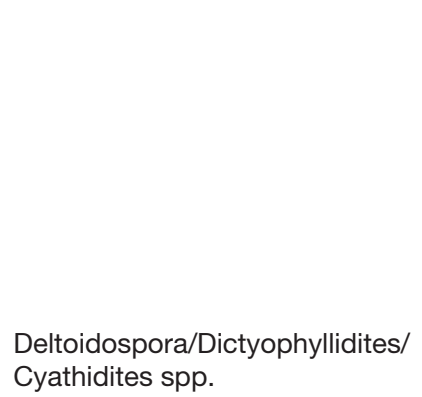

Deltoidospora/Dictyophyllidites/
Cyathidites spp. 
256.1 (1) Pachypteris rhomboidalis Pterophyllum cf. aequale Pterophyllum thomasii

256.3

256.5 (1) Pachypteris rhomboidalis

256.55 (1) Brachyphyllum stemonium 258.8

262.0

264.2

262.2 (1) Cycadolepis sp.

264.18

Brachyphyllum stemonium

\section{Microflora taxon}

Botanical affinity of microflora

Marattisporites scabratus Couper ferns (Marattiaceae)

Monosulcites/Cycadopites spp. Cycadales,

Bennettitales

Eucommiidites troedssonii

Erdtman Eucommiidites sp.

Erdtmanithecales

Number of Frequency fragments

Callialasporites dampieri (Balme) conifers (Araucariaceae)

Dev

Araucariacites sp.

Vitreisporites pallidus Couper

Classopollis torosus (Reissinger)

Couper

bisaccate pollen grains

conifers (Araucariaceae)

seed ferns (Caytoniales)

conifers

(Cheirolepidiaceae)

seed ferns or conifers

8

2

35

1

1

12

78

12

Deltoidospora/Dictyophyllidites/

Cyathidites spp.

ferns (Dicksoniaceae,

Cyatheaceae,

Dipteridaceae,

Matoniaceae)

Contignisporites sp.

Eucommiidites sp.

ferns (Pteridaceae)

Erdtmanithecales

(Reissinger) conifers

Couper

(Cheirolepidiaceae)

Deltoidospora/Dictyophyllidites/

Cyathidites spp.

ferns (Dicksoniaceae,

Cyatheaceae,

Dipteridaceae,

Matoniaceae)

Deltoidospora/Dictyophyllidites/ ferns (Dicksoniaceae,

Cyathidites spp.

Cyatheaceae,

Dipteridaceae,

Matoniaceae)

Maratiisporites scabratus Couper ferns(Marattiaceae)

Vitreisporites pallidus Couper seed ferns (Caytoniales)

Deltoidospora/Dictyophyllidites/

Cyathidites spp.

ferns (Dicksoniaceae,

Cyatheaceae,

Dipteridaceae,

Matoniaceae)

Klukisporites variegatus Couper

Vitreisporites pallidus Couper

Classopollis torosus (Reissinger)

Couper bisaccate pollen grains

ferns (Schizaeaceae)

seed ferns (Caytoniales)

conifers

(Cheirolepidiaceae)

seed ferns or conifers

Deltoidospora/Dictyophyllidites / Cyathidites spp.

ferns (Dicksoniaceae,

Cyatheaceae,

Dipteridaceae

Matoniaceae)

Klukisporites variegatus Couper

Classopollis torosus (Reissinger)

ferns (Schizaeaceae)

Couper 